\title{
Evaluatie zevende Nederlandse bosinventarisatie (NBI-7)
}

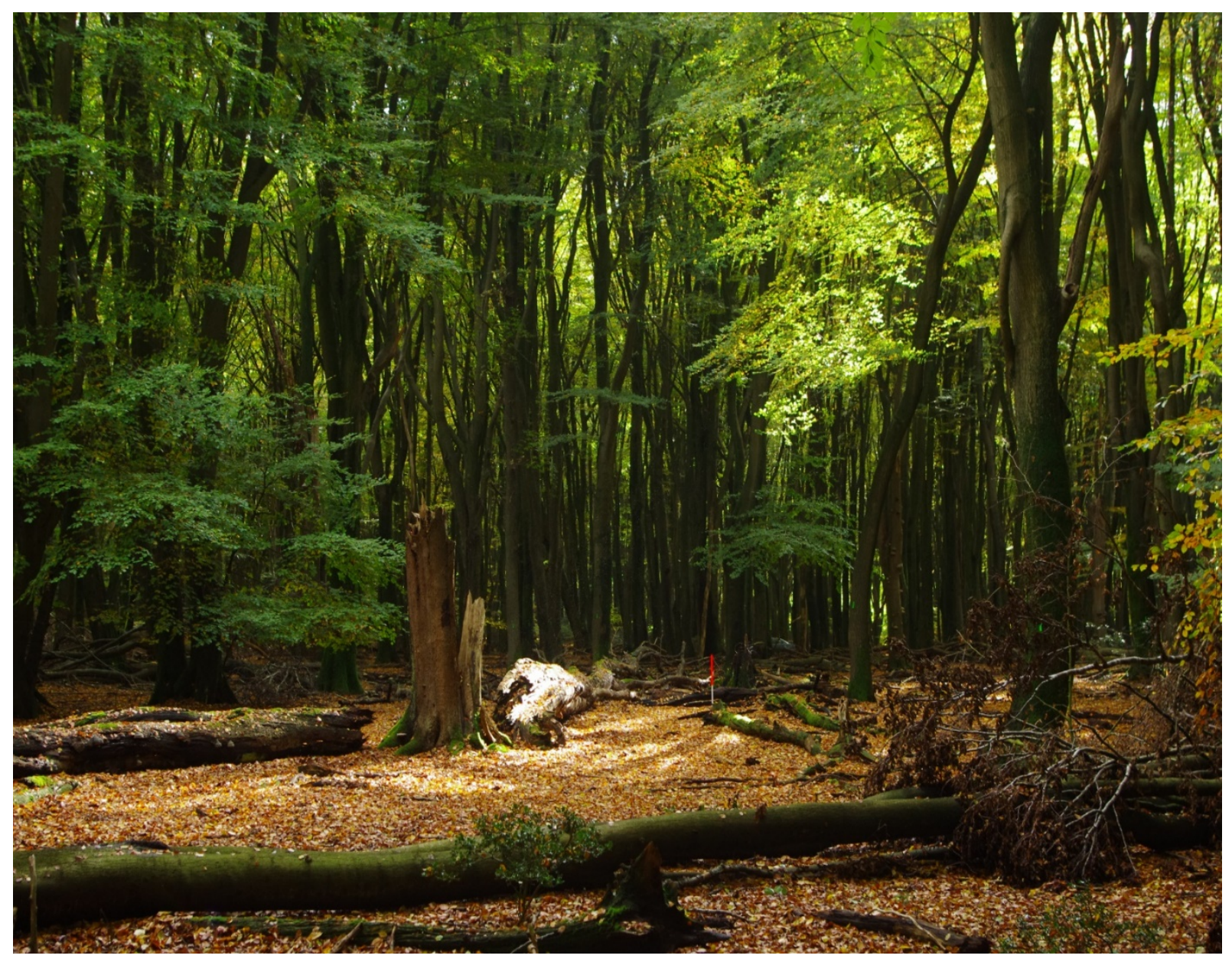

Frits Mohren ${ }^{1}$, Jan den Ouden ${ }^{1}$, Hans Jansen ${ }^{1}$, Dick Brus ${ }^{2}$, Etiënne Thomassen ${ }^{1,3}$, Rense Haveman ${ }^{4}$, Lena Schulze Middendorf ${ }^{5}$, Leen Govaere ${ }^{6}$, Harm Bartholomeus ${ }^{1}$

1 Wageningen University, Departement Omgevingswetenschappen / 2 Wageningen, Departement Plantenwetenschappen / 3 Bosgroep Zuid Nederland / 4 Rijksvastgoedbedrijf / 5 Landesbetrieb Wald und Holz Nordrhein-Westfalen / 6 Agentschap Natuur en Bos van de Vlaamse Overheid

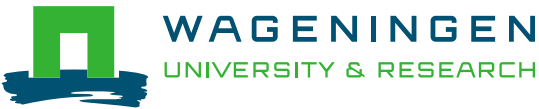

Wageningen University \& Research,

Department of Environmental Sciences, mei 2021 
Mohren, G.M.J., J. den Ouden, J.J. Jansen, D.J. Brus, E.A.H. Thomassen, R. Haveman, L. Schulze Middendorf, L. Govaere, H.M. Bartholomeus 2021. Evaluatie zevende Nederlandse Bosinventarisatie (NBI-7). Rapport Department of Environmental Sciences, Wageningen University \& Research, Wageningen; 74 blz.; 6 fig.; 6 tab.; 65 ref.

Trefwoorden: Nederlandse bosinventarisatie, steekproeftechniek, bosareaal bossenkaart, bosuitbreiding, LULUCF rapportage, bossenstrategie, koolstofopslag

Dit onderzoek is uitgevoerd door Wageningen University \& Research in opdracht van het Ministerie van Landbouw, Natuur en Voedselkwaliteit.

Een pdf-versie van dit rapport is beschikbaar via https://doi.org/10.18174/547397

(c) 2021 Department Environmental Sciences, Wageningen University \& Research. Postbus 47, 6700 AA Wageningen. CC BY-NC 4.0

Verdere verspreiding of overname van de inhoud van dit rapport is toegestaan met duidelijke verwijzing naar de bron.

Verdere verspreiding of overname van de inhoud van dit rapport is niet toegestaan voor commerciële doeleinden.

Wageningen University aanvaardt geen aansprakelijkheid voor eventuele schade voortvloeiend uit het gebruik van de resultaten van dit onderzoek of de toepassing van de adviezen.

Foto omslag: Jan den Ouden 


\section{Inhoud}

$\begin{array}{ll}\text { Samenvatting } & 5\end{array}$

$1 \quad$ Inleiding 6

1.1 Opdracht 6

$\begin{array}{lll}1.2 & \text { Doel NBI } & 7\end{array}$

$\begin{array}{lll}1.3 \text { Context } & 7\end{array}$

$\begin{array}{lll}1.4 & \text { Evaluatie en verslaglegging } & 7\end{array}$

2

NBI: Monitoring van bosontwikkeling $\quad 9$

2.1 Historie 9

2.2 Karakterisering van bos en bosontwikkeling 10

$\begin{array}{lll}2.3 & \text { Uitvoering NBI-7 } & 10\end{array}$

2.4 Vergelijking met Noordrijn-Westfalen en Vlaanderen 12

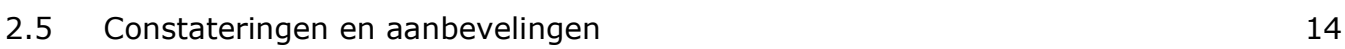

3

$\begin{array}{lr}\text { Evaluatie bestaande werkwijze } & 16\end{array}$

$\begin{array}{lll}3.1 & \text { Basiskaart (areaal, steekproefpunten) } & 16\end{array}$

3.1.1 Bossenkaart als basis voor steekproeftrekking 16

$\begin{array}{ll}\text { 3.1.2 Bossenkaart als basis voor monitoring bosareaal } & 17\end{array}$

3.1.3 Definitie van bos en grootte van bemonsterde bossen 18

$\begin{array}{lll}3.2 & \text { Opgenomen variabelen en steekproeftechniek } & 18\end{array}$

3.2.1 Variabelen: bomen, opstand, groeiplaats 18

$\begin{array}{ll}3.2 .2 \text { Steekproeftechniek } & 21\end{array}$

3.2.3 Meetmethoden (veldopname) 23

3.2.4 Mogelijke toepassing van remote sensing $\quad 24$

$\begin{array}{lll}3.3 & \text { Dataverwerking } & 27\end{array}$

3.3.1 Documentatie $\quad 27$

$\begin{array}{ll}\text { 3.3.2 Permanente en tijdelijke steekproefpunten } & 27\end{array}$

$\begin{array}{ll}3.3 .3 \text { Volumeberekening } & 27\end{array}$

3.3.4 Mutaties 28

$\begin{array}{ll}3.4 \text { Uitvoering } & 29\end{array}$

3.4.1 Project organisatie 29

3.4.2 Verantwoording van methoden en resultaten, controle en feedback 29

$\begin{array}{ll}3.4 .3 \text { Kosteneffectiviteit } & 30\end{array}$

3.4.4 Continue inventarisatie met jaarlijkse rapportage in NBI-8 31

$\begin{array}{lll}3.5 & \text { Constateringen en aanbevelingen } & 31\end{array}$

4

$\begin{array}{ll}\text { Aansluiting bij ontwikkelingen in beheer en beleid } & 35\end{array}$

$4.1 \quad$ Bosuitbreiding $\quad 36$

4.2 Biodiversiteit, koolstofvastlegging en kleinschalig beheer 36

$\begin{array}{ll}4.2 .1 \text { Biodiversiteit } & 37\end{array}$

4.2.2 Koolstofvastlegging $\quad 38$

4.2.3 Kleinschalig beheer $\quad 38$

4.3 Internationale rapportage verplichtingen $\quad 39$

$\begin{array}{lll}4.4 & \text { Constateringen en aanbevelingen } & 40\end{array}$

5

Conclusies

42

Literatuur 
Bijlage 3: Schatters voor totalen per oppervlakte-eenheid bij variabele plotstralen 


\section{Samenvatting}

Dit rapport evalueert de lopende, zevende Nederlandse Bosinventarisatie (NBI-7), met betrekking tot de gehanteerde methoden, de efficiency van de inzet van mensen en middelen, en de aansluiting bij actuele ontwikkelingen in beheer en beleid van het Nederlandse bos en de internationale rapportage verplichtingen zoals in het kader van het klimaatbeleid.

Het rapport constateert dat de NBI-7 betrouwbare gegevens levert over de structuur en samenstelling van het Nederlandse bos, de groei en ontwikkeling van het bos, en de omvang en verandering van het Nederlandse bosareaal. De NBI gegevens komen tegemoet aan een uitgebreide en diverse vraag naar informatie over het Nederlandse bos, de nauwkeurigheid en kwaliteit van de gegevens is voldoende en geeft geen aanleiding tot ingrijpende heroverweging van opzet of methodes.

Ten behoeve van de transparantie en de kwaliteitsborging is het wenselijk om de gebruikte uitgangspunten, technieken en analysemethoden helder en eenduidig vast te leggen. Voor de statistische verwerking van de steekproef wordt een aantal aanbevelingen voor verbetering gedaan. Dit betreft onder andere het overstappen van variabele steekproefcirkels naar vaste plotstralen en het verwerken van de steekproef met een alternatief ontwerp. De basis van de steekproef, de bossenkaart, voldoet voor de steekproef. Door de resolutie te vergroten kunnen ook de kleinere boselementen in het landschap beter worden gemonitord. Uitbreiding van het steekproefnetwerk met opname van kleine bosjes ( $<0,5$ hectare) wordt aangeraden. Daarnaast wordt aanbevolen om de nauwkeurigheid van de monitoring van het bosareaal waar mogelijk te verbeteren zodat ook de doelstelling van bosuitbreiding van de Bossenstrategie in volgende bosinventarisaties geëvalueerd kan worden.

De werkwijze van de NBI-7 is efficiënt en kosteneffectief. De dichtheid van het steekproefnetwerk is toereikend, en kan evenals de vijfjaarlijkse meetfrequentie gehandhaafd blijven. De meeste opgenomen meetvariabelen zijn relevant; alleen houtkwaliteit kan als variabele vervallen. De opname van dood hout zou moeten worden aangepast, en de karakterisering van de hoofdboomsoort zou kunnen worden uitgebreid met een aantal mengings-categorieën. Kenmerken en gevolgen van verstoringen dienen beter te worden gedefinieerd. Het steekproefnetwerk leent zich niet tot opname van biodiversiteitsaspecten anders dan die van houtige planten. Informatie over andere soortgroepen dient uit andere meetnetten te worden afgeleid. Voor het monitoren van koolstof dient de steekproef te worden aangevuld met informatie over de bodem.

De Nederlandse bosinventarisatie is een belangrijke basis voor discussie en gedachtenvorming. Het is daarom wenselijk om te zorgen voor goede en effectieve publieksvoorlichting. Daarbij is de vrije beschikbaarheid van de gegevens belangrijk voor de transparantie, en voor een breed gebruik van de NBI resultaten. 


\section{$1 \quad$ Inleiding}

\section{$1.1 \quad$ Opdracht}

In de aanloop naar de $8^{\mathrm{e}}$ Bosinventarisatie (NBI-8) heeft het Ministerie van Landbouw, Natuur en Voedselkwaliteit verzocht om een evaluatie van de (lopende) NBI-7. Daarbij is aandacht te schenken aan knelpunten in de huidige uitvoering en gebruikte methode, en eventuele aanpassingen gericht op kortere opnameduur (kleinere meetinspanning) en lagere kostprijs. Tevens dient te worden nagegaan aan welke eisen bosmonitoring de komende periode moet voldoen, om aan nieuwe vragen vanuit het bosbeheer en aan ontwikkelingen in bosbeleid met daaraan gerelateerde rapportageverplichtingen te voldoen. Tenslotte beschouwing van alternatieven in opzet, mede in relatie tot kostprijs.

Kernvragen in deze evaluatie zijn:

1. Gehanteerde methoden: Werkwijze in het veld, opnametechniek, bemonstering, kwaliteitsborging, aansluiting protocol bij internationale eisen, nieuwe ontwikkelingen, vijf-jaar cyclus, voortschrijdend beeld. Specifieke vragen zijn:

- Is de gebruikte techniek (technologie) en gegevensverwerking (statistiek) up-todate?

- Functioneert de huidige topografische kaart om te bepalen wat bos is en wat niet. Zijn de nadelen van de gebruikte pixelmethode overkomelijk?

- Geeft de huidige inventarisatiemethode een juiste weergave van het Nederlandse bos?

- Is het aantal steekproefpunten, mede in relatie tot de ontwikkelingen van het bosareaal (en de samenstelling daarvan), afdoende (jaarlijks verdwijnt bos, komt er bos bij, en kan een deel van de steekproefpunten niet bezocht worden)?

- Zijn de meetgegevens in relatie tot de gehanteerde definitie eenduidig? Voldoet de gehanteerde typologie?

- Kan men overstappen van een cyclus van vijf jaar naar een voortschrijdend beeld, waarbij op elk moment over de afgelopen vijf jaar kan worden gerapporteerd (in plaats van voorheen rapportages elke vijf jaar, gebaseerd op opnames tot tien jaar oud)?

- Welke internationale ontwikkelingen rond bosinventarisaties zijn er waar de NBI op moet aansluiten?

2. Efficiency: dit heeft betrekking op projectorganisatie, afstemming van taken en middelen, en uitvoering met als specifieke vragen:

- Zijn de rollen goed verdeeld (projectleiding, coördinatie, begeleidingscommissie, uitvoering, rapportage)

- Is de verdeling van de middelen voor het NBI over de verschillende onderdelen van het werk goed verdeeld?

- Hoe scoort de efficiency van het veldwerk?

- Hoe is de kwaliteitsborging geregeld?

- Hoe scoort de efficiency van het verwerken van gegevens?

- Zijn er mogelijkheden voor kostenreductie door de werkwijze te stroomlijnen? 
3. Maatschappelijke aspecten: aansluiting bij ontwikkelingen in beheerpraktijk en bosbeleid, met als specifieke vragen:

- Welke maatschappelijke behoeften en ontwikkelingen in het beheer, zoals de aandacht voor meer natuurbos, agroforestry, kleinschalig bosbeheer, bodemkwaliteit e.d., moeten terugkomen in de NBI-8?

- Welke nieuwe beleidsmatige ontwikkelingen en rapportageverplichtingen en behoeften, zoals vanuit Bossenstrategie, biodiversiteit (Natura 2000), klimaat (klimaatakkoord, LULUCF), circulaire economie, gedecentraliseerd beleid, toenemend Europees beleid (Green Deal, EU Bossenstrategie), zijn van belang voor de NBI-8?

- Welke koppelingen kunnen er gemaakt worden met andere monitoring en gegevensbronnen, bijvoorbeeld voor biodiversiteit en bodem?

- Is er een groot verschil tussen need-to-know en want-to-know bij verschillende eindgebruikers?

\subsection{Doel NBI}

De Nederlandse Bosinventarisatie (NBI) heeft als doel betrouwbare gegevens te genereren over de structuur en samenstelling van het Nederlandse bos, groei en ontwikkeling, en de omvang en verandering van het Nederlandse bosareaal, als basis voor nationale en internationale statistieken en rapportages. De NBI wordt als wettelijke onderzoekstaak (WOT) gefinancierd door het Ministerie van LNV, en uitgevoerd door een consortium onder leiding van de Wageningen Environmental Research.

\subsection{Context}

De NBI kent in principe een cyclus van vijf jaar. Ten tijde van deze evaluatie (april 2021) wordt de NBI-7 afgerond, gericht op rapportage eind 2021. De voorbereiding voor de volgende cyclus (de NBI-8) is inmiddels gestart. De planning is dat in de zomer van 2021 een plan van aanpak gereed is, waarover het desbetreffende WOTopdrachtgeversoverleg (Natuurinventarisatie) in de herfst besluit, zodat de NBI-8 kan starten in 2022.

De Begeleidingscommissie NBI heeft geadviseerd de NBI-7 te evalueren, zodanig dat de bevindingen meegenomen worden in het plan van aanpak voor de NBI-8. Dit betekent dat deze evaluatie betrekking heeft op een lopend project, waarvan de resultaten op moment van evaluatie nog niet beschikbaar zijn.

\section{$1.4 \quad$ Evaluatie en verslaglegging}

De hier beschreven evaluatie heeft plaatsgevonden op basis van beschikbare informatie, in de vorm van tussentijdse rapporten, resultaten van vooronderzoek, verslagen begeleidingscommissie, inzichten evaluatieteamleden, en informatie van opdrachtgever, uitvoerders, en leden van de begeleidingscommissie (zie Bijlage 4 voor een overzicht van gebruikte documenten en een lijst van informanten). 
De evaluatie was gericht op het identificeren van knelpunten in de gehanteerde methode en de uitvoering van de NBI-7, en het aangeven van eventuele verbeteringen daarin. Verder is onderzocht in hoeverre er extra eisen de komende jaren gesteld worden aan de monitoring van bossen, om aan toekomstige vragen (bv. aangaande ontwikkelingen in het bosbeheer) en aan huidige (LULUCF) en nieuwe rapportageverplichtingen (bijvoorbeeld vanuit het Klimaatakkoord) te kunnen voldoen.

Deze verslaglegging geeft een overzicht van de bevindingen in de vorm van constateringen en aanbevelingen; daarnaast worden er in de bijlagen concrete suggesties en overwegingen gegeven ten behoeve van de NBI-8. 


\section{NBI: Monitoring van bosontwikkeling}

\section{$2.1 \quad$ Historie}

Bijna 100 jaar geleden is besloten om de eerste Nederlandse bosinventarisatie te gaan uitvoeren. Dit initiatief ontstond naar aanleiding van het eerste Wereld Bosbouw Congres in Rome in 1926, en leidde tot de eerste Nederlandse bosstatistiek die werd uitgevoerd in de periode 1938-1942, met publicatie in 1946 (Bunschoten, 1987). Hierbij werden alleen oppervlaktegegevens geïnventariseerd. Vervolgens vond van 1952 tot en met 1963 het veldwerk voor de tweede Bosstatistiek plaats, met een uitgebreide rapportage in 9 delen door het Centraal Bureau voor de Statistiek (voor referenties zie Bunschoten, 1987).

In de tweede bosstatistiek is een oppervlakte- en houtvoorraadstatistiek gegenereerd, gegroepeerd naar gemeente per bosgebied, en in een landelijk en provinciaal overzicht. De opname was een volledige verkenning van alle opstanden $>0,5$ ha en een $10 \%$ verkenning van de opstanden van 0,1-0,5 ha alsmede van de weg- en grensbeplantingen.

Met nauwelijks enige onderbreking is na de tweede bosstatistiek begonnen met opnames voor de derde bosstatistiek, die plaatsvond van 1964 tot 1968 . Bij deze derde bosstatistiek was er nauwelijks sprake van een voorraadstatistiek, maar feitelijk alleen van een oppervlaktestatistiek. De derde bosstatistiek kan beschouwd worden als een bijstelling van een deelverzameling van de gegevens van de tweede bosstatistiek met wat meer aandacht voor recreatieve waarden en toegankelijkheid.

De vierde bosstatistiek vond plaats tussen 1980 en 1985, met een gefaseerde inventarisatie van het oppervlakte bos (1980-1983, als integrale inventarisatie van de bosterreinen, waarbij een groot aantal aspecten is onderscheiden zoals terreintype, boomsoort, bostype, kiemjaar, wijze van ontstaan, wijze van verjonging en eigendomscategorie) en overige houtopstanden (1983-1984, in de vorm van een steekproefsgewijze inventarisatie van boscomplexen kleiner dan 0,5 ha, weg- en grensbeplantingen, houtwallen e.d.), en tenslotte het functioneren van het bos (19841985 , als een steekproefsgewijze inventarisatie van de bosterreinen, met aandacht voor voorraad en bijgroei van hout, bedrijfsgegevens, doelstelling, recreatieve gegevens, gezondheid en natuurwetenschappelijke gegevens).

Om een beter inzicht te verkrijgen in de mogelijkheden van houtoogst uit het Nederlandse bos werd vervolgens tussen 1984 en 1999 het project "Houtoogststatistiek en prognose oogstbaar hout" (HOSP) uitgevoerd, waarbij in een 5-jarige cyclus op ruim 3000 permanente steekproefpunten de toestand van het bos is opgenomen. Hierbij was de eerste opname nog onderdeel van de 4e Bosstatistiek (Ritskes \& Daamen, 1987). HOSP was weliswaar geen volledige bosinventarisatie, maar leidde vervolgens tot de inrichting van het Meetnet Functievervulling bos (MFV, Dirkse et al., 2003). Deze vormde uiteindelijk de vijfde Nederlands bosinventarisatie (Dirkse et al., 2007). Feitelijk is de selectie van steekproefpunten bij HOSP een andere dan bij MFV en NBI, waardoor 
er geen relatie tussen de steekproefpunten uit de HOSP en MFV bestaat, anders dan bij de gevolgde methode met de 20 bomen (die is in beide gevallen nagenoeg het zelfde).

$\mathrm{Na}$ een onderbreking van enkele jaren leidde de behoefte aan actuele gegevens over bosoppervlak, groei en biomassa o.a. ten behoeve van internationale rapportageverplichtingen in het kader van het klimaatbeleid tot de uitvoering van de zesde bosinventarisatie in de periode 2012-2013 (Schelhaas et al., 2014), gevolgd door de huidige zevende bosinventarisatie (NBI-7, uitgevoerd de periode 2017-2021).

\subsection{Karakterisering van bos en bosontwikkeling}

Het merendeel van Nederlandse bos bestond in het midden van de vorige eeuw uit gelijkjarige monoculturen, voorkomende uit de bebossingsinspanningen aan het einde van de negentiende en het begin van de twintigste eeuw waarbij het bosareaal sterk toenam. Als gevolg hiervan was de inventarisatie vooral gericht op bemonstering van dergelijke gelijkjarige monoculturen, te zien in de aandacht voor hoofdboomsoorten en opstandsleeftijd.

Door de grootschalige bebossing van heide en stuifzanden met grove den was dit bostype sterk oververtegenwoordigd in de statistieken.

Tijdens de laatste decennia van de vorige eeuw verschoof het bosgebruik van houtproductie als primaire bosfunctie naar meervoudig gebruik, waarbij meer belangstelling ontstond voor bos als drager van biodiversiteit, en als belangrijke component voor de kwaliteit van de leefomgeving. Daardoor werd geleidelijk meer gebruik gemaakt van natuurlijke verjonging, werd het bosbeheer kleinschaliger en de bossen meer gemengd en structuurrijker. Sedert enkele decennia is daaraan toegevoegd de rol van bos als reservoir voor koolstof, en de rol van bosgroei en bosontwikkeling bij de vastlegging van $\mathrm{CO}_{2}$ in de vorm van biomassa.

Als gevolg van dit alles ontstond hernieuwde interesse voor monitoring van bosontwikkeling in de vorm van regelmatige bosinventarisaties ten behoeve van nationale en internationale rapportage verplichtingen. Door de ontwikkeling van de structuur en de samenstelling van het bos als gevolg van de veranderingen in beheer en functievervulling ontstonden ook verschillende behoeftes aan informatie over het bos zelf. Als gevolg daarvan staan de steekproeftechniek en de opgenomen variabelen voortdurend ter discussie. Een belangrijke stap is het permanent maken van de NBI steekproefpunten zodat de ontwikkelingen in de tijd beter gevolgd kunnen worden. Daarbij is het van belang om de gebruikte methode en de inrichting van de NBI regelmatig te evalueren en te bezien. Deze evaluatie is onderdeel daarvan.

\section{$2.3 \quad$ Uitvoering NBI-7}

Bij de afronding van de NBI-6 (Schelhaas et al., 2016) is een werkgroep ingesteld om te adviseren over de opzet van NBI-7, gericht op de uitvoering van een permanente bosinventarisatie in de periode 2017-2021. Deze 7e bosinventarisatie vormt de basis voor een aantal internationale rapportageverplichtingen en levert daarnaast informatie voor een aantal toepassingen in nationale context, zowel ten behoeve van beleid als 
beheer. Met ingang van 2017 is de NBI belegd als Wettelijke Onderzoekstaak (WOT) bij het Ministerie van LNV.

De methodiek van de NBI-7 bouwt voort op de methoden van de Houtoogst Statistiek en Prognose (HOSP, 1988-1999), het Meetnet Functievervulling (MFV, 2001-2005) en NBI-6 (2012-2013), aangevuld met methoden voortvloeiend uit veranderende eisen aan de inventarisatie. De uitvoering van de NBI-7 is feitelijk gebaseerd op het verslag van de voorbereidende werkgroep NBI-7, in combinatie met de resultaten van het vooronderzoek dat in 2017 is uitgevoerd. Een volledige projectbeschrijving ontbreekt. Ter voorbereiding van de NBI-7 zijn in een vooronderzoek (Clerkx et al., 2017) een aantal vragen geformuleerd. Deze worden in Bijlage I weergegeven en kort geëvalueerd met betrekking tot de opvolging in NBI-7.

Bij de start van NBI-7 is een begeleidingsgroep samengesteld uit vertegenwoordigers van de beheerpraktijk en beleid. Taak van de begeleidingscommissie is het meedenken over de gang van zaken rond de NBI-7 en suggesties te doen met betrekking tot voorkomende onderwerpen. Ook is haar taak om aan te geven welke variabelen aan de bosinventarisatie zouden kunnen of moeten worden toegevoegd, of welke variabelen zouden kunnen vervallen.

Uit gesprekken kwam naar voren dat een aantal leden van de begeleidingscommissie bij instelling als het ware op een rijdende trein terecht kwam waar op dat moment weinig aan bij te sturen viel. De totstandkoming van de NBI-6 en NBI-7 was sterk ingegeven door internationale rapportageverplichtingen, met name de klimaatrapportages voor de landgebruik en bosbouw (Land Use and Land Use Change and Forestry - LULUCF) sector (rapportages onder het VN klimaatverdrag en de boekhouding onder het Kyotoprotocol) en is uitgevoerd als continuering van eerdere inventarisaties, met name het MFV. De begeleidingscommissie geeft aan dat het doel, de werkwijze, en de verantwoording van de bosinventarisatie beter uitgewerkt en geactualiseerd zou moeten worden. Meer transparantie is nodig om te kunnen evalueren in hoeverre de gebruikte methoden voldoen aan de eisen voor benodigde rapportages. In de huidige evaluatie wordt dit verder gespecificeerd.

De resultaten van de bosinventarisaties worden vastgelegd in technische rapporten en samengevat in publicaties in de vakliteratuur (o.a. Vakblad Natuur Bos Landschap), en zijn rechtstreeks te downloaden via Database Nederlandse Bosinventarisatie 20062012 , op de website van Probos. Kerngegevens worden via websites verder verspreid (o.a. www.bosenhoutcijfers.nl). Voor een bredere toegankelijkheid van de informatie uit de bosinventarisatie is het wenselijk om de gegevens op een voor een breed publiek aantrekkelijke wijze beschikbaar te stellen, via websites of gedrukte media. Zie bijvoorbeeld https://www.natuurenbos.be/beleid-wetgeving/natuurbeheer/bosinventaris voor de resultaten van de Vlaamse bosinventarisatie (met verwijzingen naar beschikbare publicaties) of de Duitse brochures aangaande de Wald u. Holz Landeswaldinventur-2014 (via NRW.de) en de database bwi.info; voor Frankrijk zie IGN (2019). 


\subsection{Vergelijking met Noordrijn-Westfalen en Vlaanderen}

Voor een algemene indruk van het type inventarisatie, en de efficiëntie van de opnames is een vergelijking met de inventarisaties in de buurlanden Noordrijn-Westfalen en Vlaanderen uitgevoerd (zie Tabel 2.1). Op hoofdlijnen is het bos en het bosbeheer in Noordrijn-Westfalen en Vlaanderen vergelijkbaar met Nederland.

In Vlaanderen is gekozen voor een beleidsondersteunend meetnet om op grote ruimtelijke schaal (geheel Vlaanderen) en met een grote temporele schaal (tien jaar) een uitspraak te doen over de toestand en eventuele veranderingen van de Vlaamse bossen. Het opvolgen van het bosbeheer of het achterhalen van oorzaak-gevolg relaties behoren niet tot de kerntaak van de Vlaamse bosinventarisatie (vergelijkbaar met Noordrijn-Westfalen en Nederland).

In Noordrijn-Westfalen is er sprake van een combinatie van een nationale bosinventarisatie (Bundeswaldinventur) en de bosinventarisatie van het land NoordrijnWestfalen (Landeswaldinventur). De inventarisatie van Noordrijn-Westfalen is meer gedetailleerd (steekproefraster van $4 \times 4 \mathrm{~km}$ in de Bundeswaldinventur, en $2 \times 2$ in de Landeswaldinventur, i.c. viermaal meer steekproefpunten in de Landeswaldinventur).

Opvallende verschillen in de inventarisaties zijn de verschillende cycli: in NRW en Vlaanderen 10 jaar, in Nederland 5 jaar. De 5-jaarlijkse cyclus in Nederland is vooral ingegeven door de noodzaak van de regelmatige LULUCF rapportage. Daarnaast draagt een 5-jarige cyclus bij aan de nauwkeurigheid van de schatting van mortaliteit en ingroei, en de effecten van dunning die bij een 10 -jarige cyclus niet meer goed vast te stellen zijn.

Het merendeel van de opgenomen variabelen komt in de drie landen overeen. In de uitwerking ligt bij de inventarisatie in NRW meer nadruk bij het vaststellen van de houtoogstmogelijkheden, en wordt er in de inventarisatie in Vlaanderen meer aandacht besteed aan biodiversiteits-aspecten, zoals vegetatie-opnames, en aan het monitoren van de gevolgen van milieu-invloeden op het bos. 
Tabel 2.1: Algemeen overzicht van kenmerken van de bosinventarisaties in Noordrijn-Westfalen, Vlaanderen, en Nederland. Voor de precieze beschrijving en de volledige definities zie de betreffende veldprotocollen en rapportages zoals BMEL (2012, resp. 2014), Landesbetrieb Wald u Holz (2014), Govaere (2019) en Daamen et al. (2019).

\begin{tabular}{|c|c|c|c|}
\hline & $\begin{array}{l}\text { Bundeswaldinventur } \\
\text { (BWI) / Landeswald- } \\
\text { inventur (LWI) }\end{array}$ & Vlaamse Bosinventaris & $\begin{array}{l}\text { Nederlandse } \\
\text { Bosinventarisatie (NBI) }\end{array}$ \\
\hline Doel & $\begin{array}{l}\text { - Overzicht bostoestand } \\
\text { en houtoogst } \\
\text { mogelijkheden in } \\
\text { Duitsland resp. Noordrijn- } \\
\text { Westfalen } \\
\text { - Vervulling internationale } \\
\text { rapportageverplichtingen }\end{array}$ & $\begin{array}{l}\text { - Opvolgen van toestand } \\
\text { en evolutie van bosareaal, } \\
\text { boomsoortensamen- } \\
\text { stelling, bestandstype, } \\
\text { biodiversiteit } \\
\text { - Evolutie onder invloed } \\
\text { van milieuveranderingen } \\
\text { - Duurzaam bosbeheer } \\
\text { en -gebruik } \\
\text { - Internationale } \\
\text { rapportage- } \\
\text { verplichtingen (LULUCF, } \\
\text { NATURA2000 staat van } \\
\text { instandhouding } \\
\text { boshabitat) }\end{array}$ & $\begin{array}{l}\text { - Overzicht bostoestand, } \\
\text { groei en houtvoorraad; } \\
\text { informatie leveren t.b.v. } \\
\text { internationale } \\
\text { rapportageverplichtingen } \\
\text { nationale beleidsdoelen }\end{array}$ \\
\hline Frequentie & $\begin{array}{l}\text { - BWI: eens per } 10 \text { jaar, } \\
\text { "werkzaamheden" duren } \\
\text { steeds } 2-3 \text { jaar } \\
\text { - LWI: volgens de wet „in } \\
\text { regelmatige afstanden"; } \\
\text { LWI I 1998, LWI II 2012- } \\
2014\end{array}$ & $\begin{array}{l}\text { - Jaarlijks wordt } 10 \% \text { van } \\
\text { het meetnet doorlopen } \\
\text { - Continu monitoring } \\
\text { - Niet alle meetvragen } \\
\text { worden jaarlijks geüpdatet }\end{array}$ & $\begin{array}{l}\text { - Eens per } 5 \text { jaar (2017- } \\
2021 \text { ), met voornemen } \\
\text { voor doorlopende opname } \\
\text { met jaarlijks } 20 \% \text { update } \\
\text { (zie ook } 3.4 .4 \text { ) }\end{array}$ \\
\hline Bosdefinitie & $\begin{array}{l}\text { - Met bomen bezet grond- } \\
\text { oppervlak van minimaal } \\
0,1 \text { hectare en breder dan } \\
10 \text { m, onafhankelijk van } \\
\text { kadastrale weergave }\end{array}$ & $\begin{array}{l}\text { - Bosdecreet: } \\
\text { "grondoppervlakten } \\
\text { waarvan de bomen en } \\
\text { de houtachtige struik- } \\
\text { vegetaties het } \\
\text { belangrijkste } \\
\text { bestandsdeel } \\
\text { uitmaken"; } \\
\text { verwachte } \\
\text { bedekkingsgraad > } \\
50 \% \text {, minimaal } 10 \text { m } \\
\text { breed (gemeten aan de } \\
\text { buitenkant van de } \\
\text { buitenste stammen), } \\
\text { minstens } 3 \text { bomenrijen }\end{array}$ & $\begin{array}{l}\text { - NBI: met bos begroeid } \\
\text { landoppervlak, nu of } \\
\text { verwacht in de nabije } \\
\text { toekomst, met een } \\
\text { minimum oppervlak van } \\
0,5 \text { ha en een minimum } \\
\text { breedte van } 30 \mathrm{~m} \text {, en een } \\
\text { kroonbedekking van } \\
\text { minimaal } 20 \% \text { en een } \\
\text { (verwachte) boomhoogte } \\
\text { van minimaal } 5 \text { meter } \\
\text { - Voor Wet } \\
\text { natuurbescherming geldt } \\
\text { minimum oppervlakte van } \\
0,1 \text { hectare en breedte } \\
\text { van } 20 \text { m }\end{array}$ \\
\hline $\begin{array}{l}\text { Steekproef- } \\
\text { net }\end{array}$ & $\begin{array}{l}\text { - BWI: } 4 \text { x } 4 \text { km raster } \\
\text { (totaal aantal } \\
\text { steekproefpunten bijna } \\
60.000 \text {, in sommige } \\
\text { regio's wordt een } \\
\text { kleinschaliger meetnet } \\
\text { gebruikt) } \\
\text { - LWI: } 2 \text { x } 2 \text { km raster } \\
\text { met } 4 \text { steekproefpunten } \\
\text { (trakthoeken) per } 400 \text { ha, } \\
\text { dus } 1 \text { steekproefpunt per } \\
100 \text { ha (totaal aantal } \\
\text { steekproefpunten 9.300) }\end{array}$ & $\begin{array}{l}\text { - } 0.5 \times 1 \mathrm{~km} \text { raster, dwz } 1 \\
\text { steekproefpunt per } 50 \mathrm{ha} \text {, } \\
\text { totaal aantal } \\
\text { steekproefpunten } 2.700\end{array}$ & $\begin{array}{l}-1 \times 1 \mathrm{~km} \text { raster, dwz } 1 \\
\text { steekproefpunt per } 100 \\
\text { ha, totaal aantal } \\
\text { steekproefpunten } 3.190\end{array}$ \\
\hline Toegang & $\begin{array}{l}\text { - BWI veldmedewerkers } \\
\text { hebben toestemming } \\
\text { t.b.v. de inventarisatie het } \\
\text { grondgebied te betreden } \\
\text { en de inventarisatie uit te } \\
\text { voeren }\end{array}$ & $\begin{array}{l}\text { - Veldmedewerkers } \\
\text { hebben toestemming } \\
\text { t.b.v. de inventarisatie het } \\
\text { grondgebied te betreden } \\
\text { en de inventarisatie uit te } \\
\text { voeren; toch wordt } \\
\text { voorafgaandelijk } \\
\text { toestemming gevraagd }\end{array}$ & $\begin{array}{l}\text { - Toestemming van de } \\
\text { eigenaar noodzakelijk }\end{array}$ \\
\hline
\end{tabular}


Tabel 2.1 (vervolg)

\begin{tabular}{|c|c|c|c|}
\hline & $\begin{array}{l}\text { Bundeswaldinventur } \\
\text { (BWI) / Landeswald- } \\
\text { inventur (LWI) }\end{array}$ & Vlaamse Bosinventaris & $\begin{array}{l}\text { Nederlandse } \\
\text { Bosinventarisatie (NBI) }\end{array}$ \\
\hline $\begin{array}{l}\text { Inventari- } \\
\text { satie } \\
\text { (algemeen, } \\
\text { vooraf) }\end{array}$ & $\begin{array}{l}\text { - Status (bos/niet bos) } \\
\text { - Administratieve status, } \\
\text { grootteklasse eigendom } \\
\text { - Bostype, groeigebied, } \\
\text { natuurlijke } \\
\text { bosgemeenschap, FFH- } \\
\text { gebied, bedrijfsvorm } \\
\text { - Voorkomen van wild }\end{array}$ & - Status bos/ niet bos & $\begin{array}{l}\text { - Vaststelling van op te } \\
\text { nemen steekproefpunten } \\
\text { vooraf } \\
\text { - Eigendomscategorie }\end{array}$ \\
\hline $\begin{array}{l}\text { Opgenomen } \\
\text { variabelen }\end{array}$ & $\begin{array}{l}\text { Inventarisatie op } 5 \\
\text { niveaus (stralen voor } \\
\text { beschrijving van } \\
\text { structuur- en biotoop- } \\
\text { kenmerken): } \\
\text { - Straal } 25 \mathrm{~m} \text { : } \\
\text { terreinkenmerken } \\
\text { - Straal } 10 \mathrm{~m} \text { : bomen } \\
\text { tussen } 0,2-4 \mathrm{~m} \text { hoogte met } \\
\text { boomsoortenaandeel, } \\
\text { bedekking, } \\
\text { vegetatieopname (selectie } \\
\text { van soorten) } \\
\text { - Straal } 5 \mathrm{~m} \text { : opname dood } \\
\text { hout } \\
\text { - Straal } 2 \mathrm{~m} / 1 \mathrm{~m} \text { : opname } \\
\text { verjonging } \\
\text { - Prisma-telling met } \\
\text { telfactor } 4 \text { : boomsoort, } \\
\text { leeftijd, etage, Kraftse } \\
\text { boomklasse, dbh, hoogte, } \\
\text { schade, uitvlieggaten } \\
\text { bastkever, habitatbomen, } \\
\text { horstboom, boomholtes, } \\
\text { dood hout in de kroon, } \\
\text { snoei, ev. biotoopboom } \\
\text { - Prisma-telling met } \\
\text { telfactor } 1 \text { of } 2 \text { voor } \\
\text { bomen vanaf } 4 \text { m hoogte: } \\
\text { boomsoort, etage }\end{array}$ & $\begin{array}{l}\text { Inventarisatie op } 5 \\
\text { niveaus: } \\
\text { - Straal } 18 \mathrm{~m} \text { : } \\
\text { opstandleeftijd, } \\
\text { bedrijfsvorm, } \\
\text { mengingsvorm, } \\
\text { sluitingsgraad, N2000 } \\
\text { habitattype, liggend dood } \\
\text { hout (transect } 15 \mathrm{~m} \text { ) } \\
\text { - Bomenplots : soort, } \\
\text { omtrek, hoogte, status, } \\
\text { houtkwaliteit; Straal } r= \\
9 \mathrm{~m} \text { : omtrek tussen } 22 \text { en } \\
122 ; \text { Straal } r=18 \mathrm{~m}: \\
\text { omtrek vanaf } 122 ; \text { straal } \\
4.5 \mathrm{~m} \text { (<22cm omtrek en } \\
>2 \mathrm{~m} \text { hoogte): aantal } \\
\text { stammen per boomsoort. } \\
\text { - Vegetatieproefvlak } \\
16 \times 16 \mathrm{~m}: \text { opname Braun- } \\
\text { Blanquet per } \\
\text { vegetatielaag (struiken } \\
\text { tussen de } 2 \text { en } 8 \mathrm{~m} \text { en } \\
\text { bomen } \geq 8 \mathrm{~m} \text { ) }\end{array}$ & $\begin{array}{l}\text { Inventarisatie op } 4 \\
\text { niveaus: } \\
\text { - Opstand met } \\
\text { hoofdboomsoort, } \\
\text { kiemjaar, } \\
\text { verschijningsvorm } \\
\text { - Straal met } r=20 \mathrm{~m} \text { : } \\
\text { oogstactiviteiten, } \\
\text { bodemverstoring, } \\
\text { verdichting, natuurlijke } \\
\text { schade, vitaliteit, dikke } \\
\text { bomen } \\
\text { - Bomenplot met } \\
\text { variabele straal r=5-20m: } \\
\text { boomkenmerken, } \\
\text { stamkwaliteit, fase, } \\
\text { grootte } \\
\text { - Verjongingsplot met } \\
\text { straal r=8m: verjonging } \\
\text { met hoogte } \geq 50 \mathrm{~cm} \text { en } \\
\text { dbh } \leq 5 \mathrm{~cm} \text { met soort en } \\
\text { aantal; bedekking } \\
\text { vegetatielagen met } \\
\text { struiken tussen de } 2 \text { en } \\
6 \mathrm{~m} \text { en bomen } \geq 6 \mathrm{~m}\end{array}$ \\
\hline $\begin{array}{l}\text { Steekproef- } \\
\text { techniek }\end{array}$ & $\begin{array}{l}\text { - Systematisch grid; } \\
\text { trakthoeken met een } \\
\text { afstand van } 150 \mathrm{~m} ; \\
\text { steekproefcirkels; prisma- } \\
\text { telling }\end{array}$ & $\begin{array}{l}\text { - Systematisch grid; } \\
\text { gekoppelde plots; geneste } \\
\text { steekproefcirkels; } \\
\text { Braun-Blanquet vegetatie- } \\
\text { opname; } \\
\text { line intersect sampling } \\
\text { (liggend dood hout) }\end{array}$ & $\begin{array}{l}\text { - Ongelijnd systematische } \\
\text { steekproef } \\
\text { - Aparte opname } \\
\text { proefbomen voor } \\
\text { volumeschatting en } \\
\text { houtkwaliteit }\end{array}$ \\
\hline
\end{tabular}

\subsection{Constateringen en aanbevelingen}

Bij de ontwikkeling van de opeenvolgende bosinventarisaties in de loop der jaren, waarbij de $1 \mathrm{e} t / \mathrm{m}$ de $4 \mathrm{e}$ bosstatistiek relatief beperkt waren, en er feitelijk pas bij de $5 \mathrm{e}$ versie sprake is van een volledige bosstatistiek, is het belang van continuïteit evident. Dit maakt het mogelijk opeenvolgende jaren te vergelijken en conclusies te trekken over de ontwikkeling van bosareaal, samenstelling en groei.

Aanbeveling: zorg voor continuïteit in de opeenvolgende opnames, en waarborg continuering van expertise op gebied van opname en verwerking. 
NBI-6 en NBI-7 zijn sterk bepaald door internationale rapportageverplichtingen. Daarnaast worden de resultaten ook op nationaal niveau gebruikt, en is er sprake van hernieuwde belangstelling voor bosstatistiek in verband met beleidsvoornemens in onder andere de Bossenstrategie (zie voorgenomen vraagarticulatie nationaal en provinciaal, zoals besproken in begeleidingscommissie)

Aanbeveling: stem NBI-8 af op nieuwe informatiebehoefte zowel nationaal (Bossenstrategie, natuurbeleid, klimaatbeleid) als internationaal (o.a. LULUCFrapportage verplichtingen), en waar mogelijk met andere monitoringsprogramma's (zie ook hoofdstuk 4).

De resultaten van de NBI zijn van toenemend belang voor de communicatie van ontwikkelingen rondom bos, zie bijvoorbeeld de discussie over ontbossing en bosomvorming, en de discussie over kaalkap. De resultaten van de NBI zijn daarnaast zeer geschikt voor publieksvoorlichting.

Aanbeveling: bestem voldoende middelen voor publieksvoorlichting, en ontwikkel een communicatiestrategie gericht op het grote publiek (zie referenties naar voorbeelden in paragraaf 2.3 ). 


\section{Evaluatie bestaande werkwijze}

\subsection{Basiskaart (areaal, steekproefpunten)}

De bossenkaart vormt de essentiële basis voor de steekproef van de NBI. Deze kaart bepaalt het areaal waarbinnen de steekproef wordt uitgevoerd, dient ter oriëntatie tijdens het veldwerk, kwantificeert het totale Nederlandse bosoppervlak en biedt de mogelijkheid om veranderingen in het bosareaal vast te stellen. In gevoerde gesprekken tijdens deze evaluatie is herhaaldelijk naar voren gekomen dat een verbeterde bossenkaart sterk zou bijdragen aan een efficiënte uitvoering van de NBI. Verder is er behoefte vanuit de Bossenstrategie om het bosareaal eenduidig te kunnen monitoren en veranderingen daarin te kunnen vastleggen. Een accurate en regelmatig vernieuwde bossenkaart is daarvoor onontbeerlijk.

\subsubsection{Bossenkaart als basis voor steekproeftrekking}

De bossenkaart identificeert wat bos is voor de NBI en op welke oppervlakte de inventarisatie betrekking heeft. De werkwijze voor het opstellen van de bossenkaart is niet langer zoals die is omschreven in het rapport 'Toelichting bossenkaart' (Dirkse et al., 2001) ten behoeve van het Meetnet Functievervulling Bos (feitelijk NBI-5). Sinds de NBI-6 wordt de methodiek van de Basiskaart Natuur (BKN) gebruikt (zie Kramer \& Clement, 2016) voor het opstellen van de bossenkaart en als basis voor de rapportages in het kader van internationale afspraken rond koolstofmitigatie en bos (LULUCF, klimaatakkoord van Kyoto en Parijs). De BKN zelf bestaat niet meer, maar deze kaart is relatief eenvoudig samen te stellen en feitelijk is er nu een LULUCF-kaart voor de NBI beschikbaar van 2013, 2017 en de komende versie voor 2021. De LGN (Landelijk Grondgebruiksbestand Nederland) was tot op heden niet goed bruikbaar omdat de basis van deze kaart in de tijd aan verandering onderhevig is geweest en de updates niet synchroon liepen met de internationale rapportage verplichtingen. Als belangrijkste meerwaarde van de bossenkaart volgens de BKN-methode wordt de consistente tijdreeks gezien die hiermee opgebouwd kon worden, die inmiddels terug gaat tot 1970 . Vanwege wijzigingen in de LGN methodiek en omdat deze sinds 2018 jaarlijks wordt bijgewerkt is deze kaart in de toekomst mogelijk als basis te gebruiken voor de bossenkaart; iets dat in de komende tijd verkend zal worden.

De bossenkaart is in essentie een grid van $25 \times 25 \mathrm{~m}$ over heel Nederland waarbij een gridcel/pixel als bos wordt geïdentificeerd als deze overwegend uit bos bestaat. Iedere gridcel wordt dus toegekend aan het dominante terreintype. Updates van de LULUCFkaart lopen synchroon met internationale rapportageverplichtingen en vindt ongeveer om de vier jaar plaats (niet per se vlak voor een nieuwe NBI ronde).

Voor de steekproeftrekking is uitgegaan van een indeling in kilometerhokken. Iedere vierkante kilometer van Nederland heeft één steekproeflocatie ergens in dat kilometerhok (waarvan de locatie is getrokken middels een ongelijnd systematische steekproef). De steekproefpunten voor de NBI zijn eenmalig gegenereerd en worden omschreven in de toelichting op de bossenkaart (Dirkse et al., 2001). Elk steekproefpunt dat in bos valt wordt opgenomen, waarbij het pas om een bos gaat als 8 aaneengesloten pixels bos zijn ( 8 pixels zijn exact $0,5 \mathrm{ha}$ ). Aanvankelijk werd voor het 
MFV (NBI-5) de helft van de steekproefpunten als permanent punt in het veld gemarkeerd. Inmiddels zijn sinds NBI-7 alle steekproefpunten als permanent punt in het veld gemarkeerd. In het geval van bosuitbreiding betekent dit dat er al een potentieel steekproefpunt gegenereerd is, en bij bosuitbreiding op die plaats na permanente markering aan de totale steekproef kan worden toegevoegd.

De NBI-6 maakte voor het eerst gebruik van de bossenkaart met $25 \times 25$ grid. Steekproefpunten die overlappen met een bos-pixel worden, na een visuele controle op basis van de luchtfoto, bezocht. Voor de NBI-7 is de selectie uitgebreid omdat werd opgemerkt dat in de bosranden onterecht steekproefpunten niet bezocht zijn, terwijl ze wel in de voorgaande inventarisatie zaten. Deze liggen in pixels die toen niet overwegend uit bos bestonden, maar waar het steekproefpunt wel degelijk in bos ligt. Daarom is voor de selectie van de steekproefpunten een buffer van één extra pixel om de bossen van de bossenkaart gelegd, waardoor steekproefpunten die onterecht uit de NBI-6 zijn gevallen in de NBI-7 weer wel zijn opgenomen.

Vanaf de luchtfoto wordt voorafgaand aan de inventarisatie gecontroleerd of een steekproefpunt daadwerkelijk in het bos ligt. Bij randgevallen is dit moeilijk te zien; in zo een geval wordt het punt wel bezocht. Omdat ervoor is gekozen alle steekproefpunten permanent te maken, is dit feitelijk een eenmalige controleslag geweest. De opbouw van de kaart in rasters van $25 \times 25 \mathrm{~m}$ kan in het veld soms leiden tot onduidelijke situaties en bemoeilijkt de oriëntatie. In verschillende gesprekken kwam naar voren dat een bossenkaart op basis van een vectorbestand (met dus een feitelijk weergave van de begrenzingen van bos) een sterke verbetering zou opleveren.

\subsubsection{Bossenkaart als basis voor monitoring bosareaal}

In de Bossenstrategie is het voornemen uitgesproken om tegen 2030 een uitbreiding van 37.000 hectare bos te realiseren. Daarnaast is er de laatste jaren veel discussie geweest over omvormingen van bos naar andere typen natuur, zoals heide of grijze duinen, of ten behoeve van stadsuitbreiding en infrastructurele projecten zoals wegaanleg of - verbreding. Dit roept de noodzaak op om veranderingen in het bosareaal nauwkeurig te kunnen volgen zodat inzicht ontstaat in de bruto veranderingen. In de rapportages over veranderingen in bosareaal, zoals Schelhaas et al. (2017), bleek dit alleen bij benadering mogelijk.

In Nederland ontbreekt een landelijk registratiesysteem waarin mutaties in het bosareaal wordt bijgehouden. In het kader van de Wet natuurbescherming zijn eigenaren verplicht om de kap te melden wanneer dit een oppervlakte groter dan 0,1 hectare betreft. Provincies hebben hiervoor veelal een eigen systematiek die niet op elkaar zijn afgestemd. Daardoor is het niet mogelijk om inzicht te krijgen in de schaal van bosverjonging (Den Ouden \& Mohren 2020). Ditzelfde geldt voor ontbossing; ook hiervoor wordt geen centrale registratie bijgehouden. De bossenkaart is daardoor de belangrijkste informatiebron om inzicht te krijgen in de dynamiek van het Nederlandse bosareaal, maar deze biedt geen mogelijkheden om rekening te houden met kleinschalige beheervormen als groepenkap kleiner dan 0,5 ha.

Bosuitbreiding zal leiden tot nieuw bos dat niet initieel op de bossenkaart staat. Een voorgestelde werkwijze (M. Schelhaas, mond. med. 22 april 2021) is om het laatste jaar de steekproefpunten opnieuw te filteren op de bossenkaart en nieuwe steekproefpunten 
aanvullend te inventariseren. Mogelijk zou dit ook aangevuld kunnen worden met behulp van gegevens uit subsidieaanvragen voor bosaanleg of kadastrale wijzigingen, maar hiermee zou nieuw bos dat geen administratieve wijziging tot gevolg heeft buiten de boot vallen. Denk bijvoorbeeld aan het door natuurlijke successie volgroeien met bomen van heide of natuurlijk grasland.

Wij adviseren dat de werkwijze rondom de bossenkaart uitgebreider beschreven wordt, waarbij wordt aangegeven dat de veranderingen steeds een reactie zijn geweest op eerdere tekortkomingen van de kaart, zodat onduidelijk hierover wordt weggenomen. Daarbij moet ook aandacht besteed worden aan spontane bosontwikkeling op plaatsen met voorheen korte vegetatie en/of heide, zodat duidelijk wordt wanneer dergelijk spontaan bos opgenomen wordt in de NBI (of als "wandelend" bos opgenomen wordt).

\subsubsection{Definitie van bos en grootte van bemonsterde bossen}

Er zijn verschillende definities in gebruik voor het vaststellen van het bosareaal. Voor de bossenkaart van het NBI worden nu alleen bospercelen groter dan 0,5 hectare bezocht, terwijl voor de Wet natuurbescherming 0,1 hectare als ondergrens voor "houtopstanden" wordt aangehouden. In de rapportage van het totale bosareaal worden de kleinere boselementen wel meegenomen, maar hiervoor worden geen gegevens verzameld binnen de NBI. Het gaat hier om naar schatting zo'n 20.000 hectare bos (zie Arets et al. 2021), een niet verwaarloosbaar oppervlak dat naar verwachting nog verder zal stijgen bij de geplande bosuitbreiding via kleinschalige landschappelijke beplantingen. Zie verder 3.2.2.

\subsection{Opgenomen variabelen en steekproeftechniek}

\subsubsection{Variabelen: bomen, opstand, groeiplaats}

Voor een volledig overzicht van de opgenomen variabelen in de huidige steekproef wordt verwezen naar de verschillende rapportages. Tijdens gesprekken met de begeleidingscommissie en nadere bestudering van opgenomen variabelen kwamen de volgende specifieke variabelen nader aan de orde:

Bij de opname van een steekproefpunt wordt de hoofdboomsoort vastgelegd. Voor veel van de huidige bossen is het nog steeds goed mogelijk hiermee de bossamenstelling te karakteriseren, maar met de toename van de mengingsgraad en kleinschaligheid van het Nederlandse bos zal het eenduidig toekennen van een hoofdboomsoort voor steeds meer problemen leiden. Bovendien zal het vasthouden aan een louter een-soortige categorisering leiden tot een onjuiste interpretatie van de bossamenstelling wanneer de mengingsgraad toeneemt. Om dit te ondervangen zou aan de lijst hoofdboomsoorten een aantal categorieën kunnen worden toegevoegd om duidelijk gemengd bos aan te kunnen duiden. Te denken valt aan drie nieuwe categorieën: $M L=$ menging van loofbomen, $M N=$ menging van naaldbomen, $M X=$ menging van loof- en naaldbomen. Als grens voor menging kan worden aangehouden dat geen enkele boomsoort meer dan $50 \%$ van grondvlak of kroonbedekking bezet. Gemengd loofbos heeft dan niet meer dan 20\% naaldbomen, en gemengd naaldbos niet meer dan 20\% loofbomen. 
Veel verstoringsindicatoren zijn niet eenduidig gedefinieerd, waardoor onzekerheden ontstaan bij opname. Vooral bodemverdichting door insporing zou opnieuw bekeken moeten worden. Nadere objectivering hiervan kan mogelijk via vergelijking van opeenvolgende opnames van het Actueel Hoogtebestand Nederland (AHN) worden ondersteund.

Het vaststellen van droogteschade is zeer summier omschreven, terwijl dit een belangrijke verstoringsfactor is geworden in het Nederlandse bos. Vaststellen van droogteschade moet verder worden uitgewerkt in het protocol. Zo kunnen ook droogteeffecten in de ondergroei worden meegenomen. Ook dode boomtoppen kunnen duiden op droogteschade.

Veldopnemers geven aan dat de criteria voor opname vitaliteit niet helder beschreven zijn. Ook is geen duidelijke ijking gedaan van opname vitaliteit. In het algemeen verdient het overweging om na te gaan hoe effecten van klimaatverandering en andere veranderingen in groeiomstandigheden kunnen worden meegenomen in de NBI-8. Er ontstaat in toenemende mate zorg over deze invloeden op groei, mortaliteit en bosontwikkeling in het algemeen, en de NBI zou waar mogelijk informatie moeten leveren over de huidige effecten op het bos. Voor NBI-8 moet de opname van verstoringsfactoren eenduidiger worden beschreven.

Opname van de houtkwaliteit: Sinds de NBI-7 wordt voor de meest belangrijke boomsoorten de stamkwaliteit beoordeeld in een random steekproef van de individuen dikker dan $18 \mathrm{~cm}$. De bruikbaarheid van deze gegevens is beperkt; vanuit de houtverwerkende industrie is er meer behoefte aan informatie over volumes en de verhouding tussen geoogst naaldhout en loofhout. Bovendien leiden belangrijke technische ontwikkelingen in de houttoepassing en verwerking tot een toenemend belang van de chemische eigenschappen van hout, en van verwerkingsmethoden waarin de klassieke houtkwaliteitsparameters een veel minder belangrijke rol spelen. De opname van houtkwaliteit kan daarom vervallen.

Bij opname op het steekproefpunt wordt apart aangegeven of er dikke levende bomen (bomen met een diameter $>50 \mathrm{~cm}$ ) aanwezig zijn in een cirkel met straal van $20 \mathrm{~m}$. Bij een variabele straal rondom het steekproefpunt is een dergelijke aparte opname relevant omdat in jong bos (met kleine plotstraal) de aanwezigheid van dergelijke bomen vaak niet zal worden vastgesteld. Wanneer echter met vaste plotstralen gewerkt gaat worden (zie Bijlage 2) is aparte opname niet meer nodig omdat dergelijke bomen dan in de reguliere steekproef worden opgenomen. Bovendien kan zo ook probleemloos de diametergrens voor "dikke" bomen worden aangepast.

In de steekproefcirkels wordt dood hout opgenomen aan de staande en liggende stammen binnen de steekproefcirkel. Als liggend dood hout worden uitsluitend gehele bomen opgenomen. Daarmee wordt de totale hoeveelheid dood hout onderschat, omdat zware takken en andere dikke boomdelen niet worden opgenomen. Wij bevelen aan om liggend dood hout in een aparte procedure op te nemen door gebruik te maken van line intersect sampling (op basis van lijnvormige plots waarbij het kruisende dode hout wordt opgenomen).

Opname van de humusdikte is van belang om inzicht te krijgen in de dynamiek van de koolstofvoorraden op de bodem. Veldopnemers gaven aan moeite te hebben met het 
onderscheiden van de verschillende humushorizonten binnen de humuslaag. Inmiddels hebben de veldopnemers aparte instructies ontvangen voor opname van de humuslaag, waarmee dit probleem verkleind zal zijn. Regelmatige terugkoppeling en afstemming van meetprocedures moet hier een continu punt van aandacht blijven.

Gezien de meer uitgebreide toepassing van NBI gegevens ligt uitbreiding van de opgenomen variabelen voor de hand. De bossenstrategie hanteert twee hoofdoelen: biodiversiteit en koolstofmitigatie. Daartoe worden in 4.2 enkele voorstellen gedaan met betrekking tot daaruit voortvloeiende aanpassingen van de NBI.

Aansluitend op humusdikte is het wenselijk over aanvullende bodemkenmerken te kunnen beschikken, bijvoorbeeld aangaande organische stofgehalte en bodemkoolstof. Uitbreiding van de NBI hiermee zou echter een substantiële uitbreiding betekenen, en het is de vraag of het nodig is om bodemvariabelen op alle steekproefpunten op te nemen. Een werkbaar compromis hier is om in ieder geval de bodem eenmalig te karakteriseren door middel van een gedetailleerde profielbeschrijving, mogelijk aangevuld met incidentele bemonstering van bodemchemie op een subset van de steekproefpunten (zie verder 4.2.2).

De huidige steekproefneming levert relatief weinig informatie over de biodiversiteit. De meest relevante informatie betreft de boompopulatie $>5 \mathrm{~cm}$ diameter en de samenstelling van de verjonging van houtige soorten. Een voor de hand liggende uitbreiding is het verzamelen van informatie over de bodemvegetatie. In het MFV zijn vegetatie-opnames gemaakt, maar hier is in NBI-6 en NBI-7 van afgezien. Dit kan voor NBI-8 weer in de steekproef worden opgenomen. Een dergelijke uitbreiding van de steekproefopname is reeds voorgesteld voor de NBI-8.

Opname van de bodemvegetatie betekent een forse uitbreiding van de meetinspanning, en vereist een eigen specialisme waardoor het voor de hand ligt dit door aparte meetploegen uit te voeren en binnen een beperkte meetperiode in verband met aanwezigheid soorten. Verder levert dit betrekkelijk weinig informatie op met betrekking tot relevante aspecten van biodiversiteit (zeldzame soorten, indicator soorten etc.) gezien de zeer lage trefkans in willekeurige steekproefcirkels van beperkte omvang. Ditzelfde geldt voor het gebruik van het steekproefnetwerk voor het verzamelen van gegevens over andere soortgroepen zoals vogels, vlinders of kevers.

Wij adviseren daarom het steekproefnetwerk te reserveren voor informatie over boomen struiksoorten. Voor andere soortgroepen zijn uitgebreide meetnetten beschikbaar binnen het Netwerk Ecologische Monitoring. Weliswaar zijn dit geen random steekproefnetwerken, zoals de NBI, maar voor het leveren van inzichten over trends in populaties zijn deze veel beter geschikt. Binnen de huidige steekproefprotocollen van het NBI kunnen gegevens over staand en liggend dood hout en de aanwezigheid van dikke (oude) bomen als proxy worden gebruikt voor ontwikkelingen in biodiversiteit.

Het huidige steekproefpuntennetwerk van de NBI levert ook informatie over boshabitats binnen het Natura 2000 netwerk. De dichtheid van steekproefpunten is voor de meeste boshabitattypen echter onvoldoende hoog om betrouwbare gegevens te genereren over hun kenmerken. Lokale verdichting van het steekproefpuntennetwerk zou dit kunnen verhelpen maar zou de NBI sterk compliceren. Het ligt daarom meer 
voor de hand om de monitoring van Natura 2000 boshabitats via een eigen protocol vorm te geven.

\subsubsection{Steekproeftechniek}

In deze evaluatie is veel aandacht besteed aan de gebruikte steekproeftechniek. Over het geheel beschouwd voldoet het gebruikte steekproefontwerp qua betrouwbaarheid en representativiteit van de resultaten. Hieronder worden enkele aspecten kort behandeld, met name gericht op verdere verbetering van de gehanteerde methode. Een meer gedetailleerde bespreking is opgenomen in Bijlagen 2 en 3. Een aantal van de daarin behandelde onderwerpen wordt hier kort herhaald.

Opname van bos < 0.5 ha. In NBI-7 wordt de steekproef gelegd op alle bos groter dan 0,5 ha. Hiermee blijven de bossen tussen 0,1 en 0,5 hectare buiten beeld, tezamen goed voor een oppervlakte van omstreeks 20.000 hectare. Dit is een substantieel deel van het totale bosoppervlak, en zal naar verwachting verder toenemen bij de voorziene uitbreiding van het bosareaal. Ondanks hun geringe grootte dragen kleine boselementen bij aan de koolstofvastlegging, aan de biodiversiteit in het landschap en oogst van hout (Valdes et al. 2020).

De huidige steekproefmethode is ingericht op aaneengesloten bossen van grotere omvang. Kleine landschapselementen die onder de definitie van bos vallen vereisen vaak een aangepaste opnamemethodiek. Die werd in de afgelopen bosinventarisaties niet verder uitgewerkt. In Vlaanderen worden dergelijke elementen wel opgenomen in de VBI, waardoor de inventarisatie is afgestemd op de wettelijke definitie van bos. Ook in de NBI-4 zijn deze kleine elementen nog meegenomen in de inventarisatie.

Door deze kleine elementen niet op te nemen blijft een substantieel deel van het Nederlandse bosareaal onbeschreven. Het is wenselijk om de steekproef uit te breiden met opname van kleine bosjes tussen 0,1 en 0,5 hectare (zie verder 3.2.2). Hierbij moet in de rapportage zorg gedragen worden voor de continuiteit ten aanzien van voorgaande opnames door de kenmerken van bos kleiner dan 0,5 hectare apart, althans duidelijk geïdentificeerd, te rapporteren.

Variabele plotstraal. Bij de opname wordt een variabele plotstraal gebruikt, die steeds zodanig wordt gekozen dat er zich minstens 20 bomen in de steekproefcirkels bevinden. Deze methode leent zich goed in bossen met een relatief eenvoudige structuur waarbij de meetefficiëntie wordt vergroot omdat, vergeleken met een vaste plotstraal, wordt voorkomen dat in jong bos veel bomen moeten worden gemeten of in oud bos juist weer erg weinig bomen worden gemeten. Nadeel van de variabele plotstraal is dat de schatting van gemiddelde kenmerken in het plot niet geheel zuiver is, maar de afwijking is dermate klein dat het gebruik van variabele plotstralen voldoet voor de NBI (zie Bijlage 3).

Met het steeds kleinschaliger worden van het Nederlandse bos, en het toenemen van de complexiteit van de structuur, met name de verticale gelaagdheid, leidt het gebruik van variabele plotstralen tot problematische situaties. Bij een opgroeiende verjonging onder scherm, of bij doorgroeien van struikvormige soorten als hazelaar en krent, leidt het opnameprotocol tot het hanteren van kleine plotstralen waardoor de representativiteit voor de grote bomen afneemt. Bovendien wordt de opname complexer omdat bij verkleiningen van de plotstraal eerder gemeten bomen niet meer binnen de steekproefcirkel vallen en alsnog apart opgenomen moeten worden. Om deze 
problemen te voorkomen kan het best worden overgegaan tot het gebruik van vaste steekproefcirkels. Daarbij kan de werkwijze van de Vlaamse bosinventarisatie als voorbeeld dienen, en gebruik worden gemaakt van een aantal steekproefcirkels van opeenvolgende grootte, afhankelijk van de grootteklassen van de aanwezig bomen.

Aantal plots. Door te kiezen voor een dichtheid van de steekproefpunten van 1 per 100 ha wordt het Nederlandse bos vrij intensief bemonsterd: in totaal zijn in NBI-6 3393 steekproefpunten opgemeten. Dit leidt tot een hoge betrouwbaarheid van de opname, over het geheel genomen 3,7\%. Verlaging van het aantal steekproefpunten is mogelijk, maar daardoor worden schattingen van kenmerken van minder algemene eenheden snel minder betrouwbaar (zie Bijlage 2). De huidige dichtheid aan steekproefpunten wordt als toereikend gezien en behoeft geen aanpassing.

Selectie op te nemen plots. In NBI worden cirkelvormige plots gekozen door punten te loten met een systematisch ongelijnde steekproefopzet. De punten vormen de middelpunten van de plots. Bij het loten van de punten wordt gebruik gemaakt van een kaart. Deze kaart fungeert als steekproefkader. Punten die buiten de onderzoekspopulatie vallen zoals weergegeven op de kaart, vallen af. Dit is correct wanneer de geheel cirkelvormige plot rond dit punt buiten de populatie valt. Echter wanneer een deel van de cirkelvormige plot volgens de kaart wel tot de populatie behoort, moet deze plot wel meegenomen worden. Wanneer je deze cirkels niet meeneemt hebben de bomen aan de rand van de onderzoekspopulatie een kleinere kans om geselecteerd te worden. Deze kleinere insluitkans moet dan gekwantificeerd worden, en gebruikt worden in de schatters van het populatie-taal en populatiegemiddelde.

Voor het schatten van het populatie-totaal wordt voor deze cirkels het totaal van de doelvariabele bepaalt in het deel van de cirkel dat binnen de onderzoekspopulatie valt. Wanneer het populatie-gemiddelde wordt geschat met de ratio-schatter (zie Bijlage 3), telt alleen de oppervlakte van de cirkel binnen de onderzoekspopulatie mee.

Herhaalde opnames. In de huidige NBI worden steeds vaste punten opnieuw opgenomen. De verwerking van de gegevens vindt plaats door de steekproef te beschouwen als een "Continuous Forest Inventory" (CFI). Om verschillende redenen (zie Bijlage 2) is het aan te bevelen om de steekproef te verwerken als "Sampling with Partial Replacement" (SPR).

Volumetabelllen en volumetarieven. Als onderdeel van de steekproef worden op elk plot een of meer proefbomen gemeten. Via soort-specifieke volumefuncties (de basis van de volumetabellen) wordt dan per proefboom het volume berekend, en vervolgens worden deze volumes gerelateerd aan de diameter. Dit levert het volumetarief, en functie waarmee voor iedere boom in de steekproef het volume kan worden geschat. Uit een nadere beschouwing van de gebruikte volumefuncties (zie bijlage 2) bleken inconsistenties te zitten in de gebruikte parameterwaarden. Ook de toekenning van soorten, waarvoor geen soortspecifieke volumetabel beschikbaar was, aan soortgroepen waarbij gebruik wordt van de volumetabel van een andere soort, was niet eenduidig. Een nauwgezette herziening en documentatie van de gebruikte parameters voor de volumetabellen is nodig.

$\mathrm{Er}$ is behoefte aan een verbeterde set van functieparameters voor de volumetabellen. De zuiverheid van de huidige set is onbekend, en de onderliggende steekproef van 
proefbomen was vooral gericht op dunningsbomen binnen opstanden (zie bijlage 2). Het is erg wenselijk om nieuwe functieparameters te schatten voor de volumetabellen.

Nieuwe laserscanningtechnieken lijken veelbelovend om dergelijke functies op efficiënte wijze te schatten.

Voor de functie van het massatarief maakt de NBI gebruik van een tweedegraads polynoom. Dit kan leiden tot grote afwijkingen in het geschatte volume bij lage diameters. Gebruik van een power-functie met regressiegewichten kan dit voorkomen (zie bijlage 2). Daarnaast worden de volumetarieffuncties voor elke NBI opnieuw uitgerekend. Dit is onwenselijk. Beter is het om bij opeenvolgende inventarisaties eenzelfde gecombineerd tarief te hanteren (zie bijlage 2 ).

\subsubsection{Meetmethoden (veldopname)}

Voor de opname van de steekproefcirkels worden nu twee vaste meetploegen ingezet. Hierdoor kan efficiënt worden gemeten omdat niet steeds nieuwe opnemers hoeven te worden opgeleid. De door hen te meten steekproefcirkels grofweg verdeeld tussen Noord- en Zuid-Nederland. Door deze geografische verdeling dreigt het gevaar voor systematische verschillen in steekproefopname indien deze twee ploegen onvoldoende geharmoniseerd werken. Het is dus van groot belang voor de kwaliteit van de steekproef dat alle betrokken opnemers regelmatig de meetprotocollen gezamenlijk doornemen en oefenen in het veld. Door de corona-maatregelen is dit het afgelopen jaar niet gebeurd. Dit zou zo snel mogelijk weer moeten worden opgepakt. Onderlinge communicatie en afstemming zou ook buiten de geplande bijeenkomsten gefaciliteerd kunnen worden.

De organisatie van de steekproefopname is gesplitst. De communicatie met terreineigenaren voor het verlenen van toestemming tot betreding van de terreinen is in handen van Probos. Zij leggen per brief contact met de terreineigenaren, maar in de praktijk blijkt dit onvoldoende te kunnen worden uitgewerkt. Een deel van de eigenaren geeft in eerste instantie geen toestemming en een deel reageert niet. In de praktijk wordt er onvoldoende ingezet op het opnieuw contacteren van deze groepen om alsnog toestemming te kunnen regelen (wanneer gebruikt gemaakt wordt van SNL geldt als voorwaarde dat het terrein voor monitoringswerkzaamheden moet kunnen worden betreden; uitgezocht kan worden of dit ook voor de NBI geldt). Extra inzet (en middelen) voor het verkrijgen van toestemming zou de kwaliteit van de steekproefopname sterk kunnen verbeteren.

Wanneer geen expliciete toestemming is verkregen voor het opnemen van steekproefpunten wordt het aan de veldopnemers overgelaten om eventueel toch toestemming te krijgen. Daarnaast blijken lokale beheerders van grote terreinorganisaties niet altijd op de hoogte van centrale afspraken over toegang tot terreinen. Dit heeft tot gevolg dat veldopnemers veel tijd moeten besteden aan het regelen van toestemming. In sommige gevallen worden plots gemeten zonder dat er expliciet toegang is verleend. In dergelijke gevallen wordt aan opnemers gesuggereerd "toch maar gewoon het bos in te lopen". Dit roept onzekerheid op bij opnemers, en is ongewenst. Veldopnemers geven aan dat voor de huidige meetrondes in het NBI-7 in een dag met 8 werkuren gemiddeld maximaal 7 plots kunnen worden opgenomen. In de praktijk, met voorbereidingstijd meegerekend, is het aantal plots eerder 6 per dag omdat ongeveer $10 \%$ van de werktijd nodig is voor het regelen van toegang tot 
terreinen. Het zou de efficiency van de veldopname sterk ten goede komen als toegang tot de steekproefpunten geen verantwoordelijkheid zou zijn voor de veldopnemers. Hier geldt dus dat extra inzet (en middelen) voor het verkrijgen van toestemming de efficiency van de steekproefopname kan vergroten, en voorkomt dat veldopnemers voor moeilijke eigen afwegingen komen te staan.

Een klein deel van de steekproefpunten blijkt in de praktijk onbereikbaar. Duidelijk onbereikbare punten worden ook niet meer bezocht. Overwogen kan worden deze steekproefpunten te vervangen door een nieuwe trekking binnen het km-hok. De efficiency kan verder worden verhoogd door in de centrale database reeds op het eerste werkblad aan te geven of een steekproefpunt op een bijzondere locatie ligt of andere logistieke bijzonderheden. Dit kan veel verrassingen in het veld voorkomen.

\subsubsection{Mogelijke toepassing van remote sensing}

In Bijlage 2 van het vooronderzoek NBI-7 beschrijven David Borgman en Nico Spliethof (Borgman Beheer Advies) de mogelijkheden en beperkingen van (remote) sensing technieken als toevoeging op of (deels) vervanging van de huidige inventarisaties. Het rapport is in 2017 opgesteld.

\section{Terrestrial Laserscanning}

Terrestrial Laser Scanning (TLS) is het inscannen van objecten met behulp van lasertechnologie vanaf een statisch punt op de grond. De beschrijvingen en aanbevelingen in het vooronderzoek rond het gebruik van TLS zijn valide en ondanks dat er de afgelopen jaren voorzichtige stappen zijn gemaakt is een directe implementatie ter vervanging van de huidige opnamemethode niet aan de orde. Ook voor andere remote sensing methoden geldt dat de huidige kernset van variabelen niet efficiënt en niet met voldoende nauwkeurigheid kan worden ingewonnen.

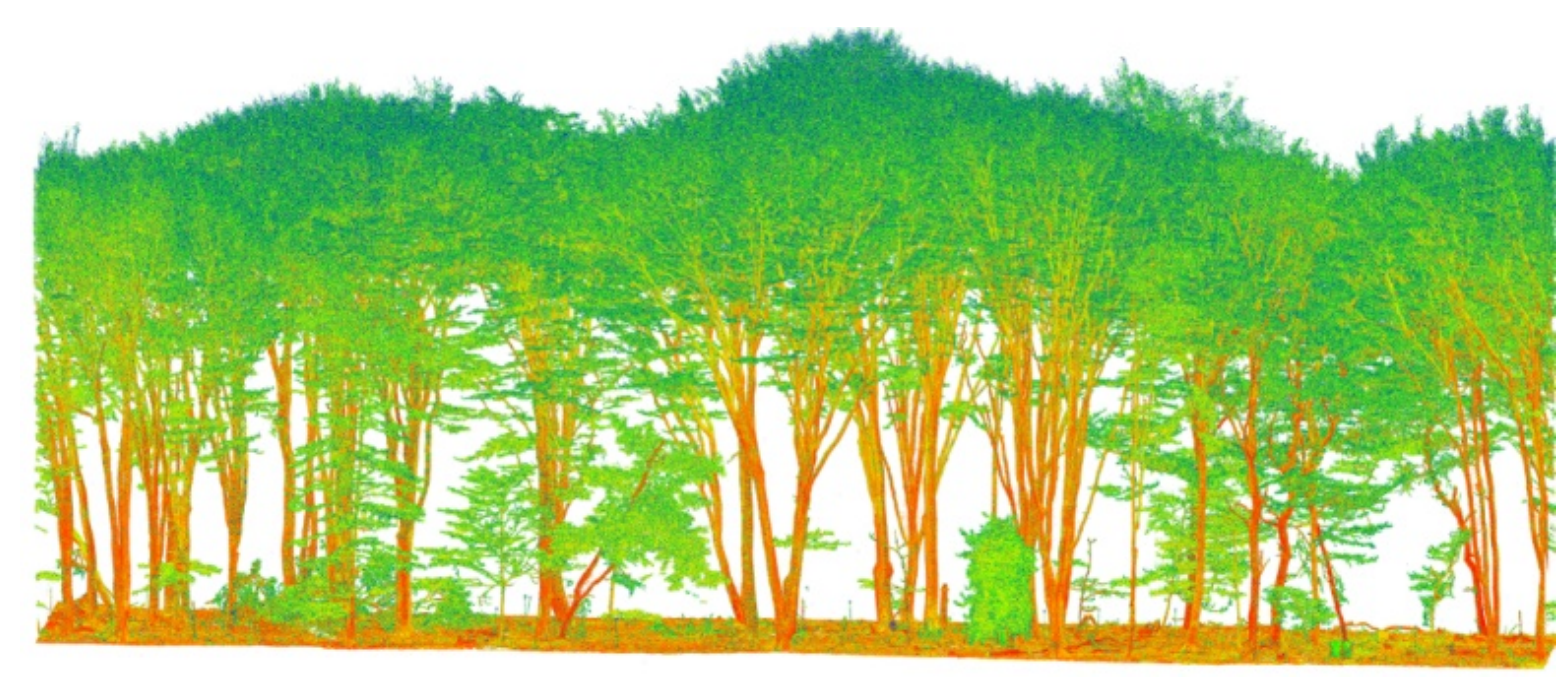

Figuur 1: Zijaanzicht van een dwarsdoorsnede van het bos, verkregen via Terrestrial Laser Scanning. Met deze techniek kan de bosstructuur in groot detail worden vastgelegd.

Een aantal opmerkingen:

1) Technische ontwikkelingen in Mobiele Laser Scanning (MLS), waarbij de scanapparatuur per voertuig of te voet wordt verplaatst en continu inmeet, zorgen 
voor een forse afname van de inwinnings- en verwerkingstijd, wat terecht als beperkende factor van TLS wordt genoemd. Een eerste verwerking gebeurt direct bij het opnemen, waardoor in het veld al een geregistreerde puntenwolk beschikbaar is. De stap naar een daaruit afgeleide stam-positie-kaart, waaraan observaties kunnen worden toegevoegd is enkel een technische implementatie stap. TLS biedt een hogere nauwkeurigheid, maar kost aanzienlijk meer tijd, zowel tijdens de inwinning als verwerking. Een pilot study zou zich daarom het beste kunnen richten op het gebruik van (state of the art) MLS apparatuur voor het inwinnen van LiDAR data op plot niveau.

2) Wat betreft soortherkenning zijn er de laatste jaren stappen gemaakt (Terryn et al. 2020, Akerblom et al. 2017, Lin \& Herold 2016). Dit zijn veelal casestudies maar tonen aan dat er mogelijkheden liggen met het gebruik van Machine Learning en Deep Learning technieken. Om dergelijke algoritmes te kalibreren voor de Nederlandse situatie zijn er echter trainingsdata nodig. Inzameling van die gegevens vereist flinke investeringen. Mogelijk kan een start gemaakt worden door dit onderwerp in de hierboven genoemde pilotstudie mee te nemen.

3) TLS is wel een techniek waarmee het probleem van de volumefuncties (zie elders in dit rapport) zou kunnen worden opgelost omdat non-destructief volumes van individuele bomen kunnen worden gemeten (spilhout, werkhout, dikhout =stam +dikke takken, en takhout). Met TLS kunnen de stam en kroon van een boom zeer nauwkeurig driedimensionaal in beeld gebracht worden. Door een dataset op te bouwen met de belangrijkste Nederlandse boomsoorten kunnen de schattingen van houtvolume- en koolstofvoorraden verbeterd worden. Zie Bijlage 2 voor een nadere toelichting op dit punt. Dit kan los van de NBI zelf worden uitgevoerd.

\section{Bepaling van bosstructuur en dynamiek door Remote Sensing.}

In het vooronderzoek voor NBI-7 is wat betreft landsdekkende data met name het Actueel Hoogtebestand Nederland(AHN) genoemd; een kaart van Nederland met gedetailleerde hoogtegegevens. Echter, deze databron biedt een te hoge onnauwkeurigheid wanneer het vergeleken wordt met observaties op plotniveau. Boomhoogtebepaling vanuit AHN is acceptabel wanneer het gaat om loofbossen, maar laat aanzienlijke (enkele meters) afwijkingen zien bij naaldbossen. De verwachting dat de diameters van de bomen bij een volgende editie van AHN nauwkeurig bepaald kan worden is waarschijnlijk ijdele hoop.

Ten eerste is het maar de vraag of volgende edities van AHN ingewonnen gaan worden met de vereiste hogere puntdichtheid. Financiering van deze dataset komt momenteel niet vanuit deze toepassing, waardoor er weinig tot geen invloed is op de inwinningseisen. Daarnaast zijn er inderdaad studies die de DBH weten te bepalen uit high density Airborne LiDAR data, waarvan Buksch et al. (2014) ook een Nederlands bos in hun analyse hebben meegenomen. Het is echter nog niet duidelijk of dit ook goed gaat bij kleinere DBH klassen (in de analyse van Buksch et al. (2014) heeft de dunste boom een diameter van $30 \mathrm{~cm}$ ) en hoe de overige bosstructuur (dichtheid van kronendak en ondergroei) de metingen beïnvloedt en dus wellicht ook een nauwkeurige bepaling van de DBH in de weg staat. Deze problemen worden ook beschreven in Buksch et al. (2014). Daarbij is het de vraag of de daar gegeven (on)nauwkeurigheid in het plotgemiddelde van de $\mathrm{DBH}(\sim 3 \mathrm{~cm})$ acceptabel is.

Voor het meten van bosstructuur (mate waarin sprake is van verschillende vegetatielagen, en hoe verschillende structuurtypen over de ruimte zijn verdeeld) zou 
het wel mogelijk kunnen zijn om via bewerking van de AHN puntenwolk een -in principe- landsdekkende inventarisatie te doen.

Remote sensing technieken zullen zeker niet in staat zijn de huidige bosinventarisatie te vervangen, maar kunnen wellicht een opstap zijn naar het inventariseren van veranderingen binnen het gehele bosareaal. Hiermee is er met name flinke winst te behalen wat betreft update frequentie. In toevoeging op de bespreking van remote sensing in het vooronderzoek NBI-7 kan een aantal producten worden genoemd die in de buurt komen van real time monitoring:

1: RADDALERT: momenteel focust deze applicatie zich op het detecteren van verstoringen in tropische bossen, waarbij er met behulp van RADAR satellieten (Sentinel-1) veranderingen in bosstructuur gedetecteerd worden met een ruimtelijke resolutie van 10 meter en een temporele frequentie van circa 1 week (http://raddalert.wur.nl). Implementatie voor de Nederlandse situatie vereist wellicht hercalibratie van modellen, een conversie van het concept naar de Europese context. Belangrijke voordelen zijn dat RADAR data ongevoelig zijn voor bewolking, waardoor continue updates mogelijk zijn, en dat de data vrij beschikbaar zijn.

2: Bedrijven als NEO (in een consortium met WEnR \& Geodan: https://boomregister.nl/) en Cobra (https://bomenmonitor.nl/)hebben in de afgelopen jaren remote sensing gebaseerde systemen opgezet voor het in kaart brengen en monitoren van alle bomen in Nederland. Dit werkt vooralsnog beter voor urbane bomen en bomen in open landschappen dan voor aaneengesloten bosgebieden. De daar opgebouwde kennis kan echter zeer waardevol zijn.

3: Globalforestwatch.org: Initiatieven om bossen wereldwijd in kaart te brengen, zoals https://www.globalforestwatch.org/ kunnen wellicht als inspiratie dienen voor bosmonitoring in Nederland. Het is belangrijk om hierbij aan te merken dat de resolutie van de data en de betrouwbaarheid van de schattingen op het niveau van een land als Nederland te laag is voor een directe toepassing binnen Nederland.

4: GEDI: Voor directe bepaling van biomassa is momenteel het GEDI instrument gemonteerd op het ISS (https://gedi.umd.edu/ ). Dit instrument is speciaal ontwikkeld voor het wereldwijd monitoren van biomassa, maar door de baan van het ISS wordt hiermee enkel de helft van Nederland gemeten. Dit biedt dus geen directe oplossing voor nu, maar het is wel goed te weten dat deze ontwikkelingen ook gaande zijn. Hoge resolutie satellietbeelden worden gratis ontsloten door het NSO via het satellietdataportaal (https://www.satellietdataportaal.nl/). Zo zijn daar maandelijkse SuperView data beschikbaar met een resolutie van $50 \mathrm{~cm}$ (RGB) en $2 \mathrm{~m}$ (RGB +NIR). Daarnaast zijn eerder genoemde Sentinel $1 \& 2$ data beschikbaar via de ESA.

Met betrekking tot de betrouwbaarheid en de nauwkeurigheid van de diverse geschatte parameter is het denkbaar dat gegeven de ruimtelijke steekproefopzet, de betrouwbaarheid verder kan worden vergroot door gebruik te maken van remote sensing beelden in combinatie met bijvoorbeeld machine learning technieken in zogeheten model-assisted schatters. Het valt buiten het bestek van deze evaluatie om daar concrete aanbevelingen over te doen, maar het is aan te bevelen de 
ontwikkelingen op dit gebied te volgen, en te zijner tijd te bezien of dit een efficiency winst voor de NBI oplevert.

\subsection{Dataverwerking}

\subsubsection{Documentatie}

Bij het beoordeling van de dataverwerking is bekeken hoe dat in NBI 6 is gebeurd, omdat hiervan zowel de rapportage (Schelhaas et al., 2014) als de database (NBI-2012MFV-2006.mdb) beschikbaar zijn. Wanneer we de databases Plotgegevens en Boomgegevens matchen blijken er echter discrepanties tussen beiden te bestaan. Zo kwam plot 55982 wel in de Boomgegevens voor en niet in de Plotgegevens. Iets vergelijkbaars deed zich voor bij plot 52831 (geen bosterrein volgens Plotgegevens, maar permanent plot in Boomgegevens).

Verder bleken de in Tabel 10.2 (in Schelhaas et al., 2014) gepresenteerde volumes na controle voor het totaal te kloppen, maar de verdeling over de soorten bleek niet te reconstrueren omdat de indeling in soortgroepen kleinere manco's vertoonde. Zo is nergens vermeld tot welke groep lijsterbes gerekend is en voor zwarte els moest ook grauwe els meegeteld worden; logisch maar in strijd met de instructie.

Een heldere vastlegging van alle rekenprocedures ontbreekt op dit moment. Het is van belang een draaiboek voor dataverwerking te maken en controlefases in te bouwen. Ook moet volledig worden gedefinieerd welke groepsindeling van boomsoorten wordt gebruikt voor presentatiedoeleinden maar ook voor de keuze van de volumetabel en het volumetarief en de motivatie voor die keuze.

\subsubsection{Permanente en tijdelijke steekproefpunten}

Voor de verwerking van de opnames naar de huidige toestand (in de praktijk dus op een gemiddeld tijdstip in het meettijdvak) maakt het niet uit of de steekproefpunten een tijdelijk of permanent karakter hebben. Gaat het om verschillen tussen opeenvolgende bosinventarisaties te bepalen, dan zijn er twee manieren om dit te verwerken, namelijk met CFI (Continuous Forest Inventory) en SPR (Sampling with Partial Replacement), zie De Vries (1986). Er is gekozen voor CFI, waarin alleen de permanente steekproefpunten worden gebruikt. Echter, met SPR worden alle steekproefpunten gebruikt en worden de verschillen (bijgroei, ingroei, sterfte en kap, maar ook wijzigingen in grondgebruik) nauwkeuriger geschat. _In NBI-7 worden in principe alle steekproefpunten permanent maar om de wijzigingen naar NBI- 6 te schatten wordt SPR als verwerkingsmethode aanbevolen, te meer daar het een illusie zal blijken dat in de toekomst geen steekproefpunten vervangen zullen moeten worden. Ook dit punt dient aandacht te krijgen in de beschrijving van de procedures.

\subsubsection{Volumeberekening}

Om het volume te schatten wordt gebruik gemaakt van een Double Sampling Methode. In fase 1 worden op ieder steekproefpunt de diameters gemeten en in fase 2 wordt van iedere boomsoort die in het plot voorkomt één proefboom geselecteerd, waarvan ook de hoogte wordt gemeten. Vervolgens wordt het boomvolume bepaald met een volumetabel (ook wel massatabel genoemd). Dit betreft een outplace element in het 
steekproefontwerp, omdat de volumetabel is gemaakt met gegevens die buiten de steekproefpunten zijn verzameld. Daar blijken wat fouten in te zitten en enige onduidelijkheden (zie Bijlage 2). Vervolgens wordt een zogenaamd volumetarief berekend waarmee van iedere boom uit fase 1 het boomvolume bepaald. Na een indeling in boomsoortgroepen volgt het totale volume. In Bijlage 2 wordt in formules uitgelegd hoe het volume geschat wordt en hoe de variantie ervan berekend kan worden. Er worden drie variantiecomponenten onderscheiden, 1 voor fase 1 (80\%) 2 voor fase 2 volumetarief (15\%) en 3 voor de externe volumetabel (5\%). Idealiter zou een nieuw inplace volumetarief gemaakt moeten worden (waarbij onderzocht kan worden in hoeverre dit via TLS of MLS kan worden gerealiseerd). Dit brengt naar verwachting hoge extra kosten met zich mee; als tussenoplossing zouden de parameters voor de volumetabellen opnieuw vastgesteld moeten worden. Bij de constructie van het volumetarief dient maar één regressiegewicht gebruikt te worden (Cunia, 1964) en bij voorkeur het model van Berkhout (1920), waarbij in dat geval Jack-knifing gebruikt moet worden om de variantie te berekenen. Het gebruikte volumetarief dient hetzelfde zijn in opeenvolgende inventarisaties.

\subsubsection{Mutaties}

Wijzigingen in bossamenstelling en landgebruik worden in de rapportage van NBI-6 spaarzaam in kaart gebracht. Naast Figuur 6.1 (in Schelhaas et al., 2014), waarin een mooi overzicht wordt gegeven van het volwassen worden van het Nederlandse bos, gaat het vooral om wat opmerkingen in de tekst. Mooie voorbeelden geven Daamen \& Ritskes (1987) in hun analyse van de wijzigingen tussen de $1 \mathrm{e}$ en $4 \mathrm{e}$ bosstatistiek, dit zou als inspiratie kunnen dienen.

In Bijlage 7 van Schelhaas et al. (2014) wordt een formule gegeven voor de schatting van de volumebijgroei. Deze formule werd ontwikkeld op basis van werk van Munro (1974) door Daamen en Schoonderwoerd (1990), bij de analyse van de HOSP data en was daar veel efficiënter omdat die bijgroei gerelateerd kon worden aan Kraftse boomklassen, die destijds in HOSP gebruikt werden, en voor allerlei bijzondere omstandigheden zoals bovenstaanders of bijzondere terreintypen. Met de vergelijkbare codering "Sociale positie in kronendak" in NBI-7 is dat opnieuw mogelijk, maar de noodzaak hiertoe ontbreekt in het geval via de voorgestelde SPR techniek wordt gewerkt (zie 3.3.2), en wanneer door het gebruik van de volumetarieven de boomvolumes van de individuele bomen op twee tijdstippen bekend zijn.

Ook wordt bijgehouden of een boom gekapt wordt, dood gaat of nieuw is. Voor een nieuwe boom kan dat gaan om ingroei (nu dikker dan de meetdrempel) of ongrowth (door aanpassing straal rond het steekproefpunt). Hiermee kan de volledige natuurlijke en kunstmatige dynamiek berekend worden.

Wijzigingen in de bossamenstelling en landgebruik kunnen ook veroorzaakt worden door verandering in de steekproeftechniek. Dit betreffen dan de zogenaamde statistische mutaties. Het wordt aanbevolen om mutaties in bossamenstelling en landgebruik beter in kaart brengen. Door steekproef te verwerken met SPR en volumetarieven kan de dynamiek rechtstreeks worden geschat en kan het gebruik van bijgroeiformules worden gestaakt. Indien wordt overgestapt op vaste steekproefcirkels is het wenselijk om de statische mutaties te schatten door op bijvoorbeeld 5 tot $10 \%$ van de plots zowel met de oude als de nieuwe methode te inventariseren. 


\section{$3.4 \quad$ Uitvoering}

\subsubsection{Project organisatie}

Ten behoeve van NBI-7 is een consortium samengesteld bestaande uit Wageningen Environmental Research (WEnR, coördinatie), Bureau Silve (steekproefopzet, veldwerk, gegevensverwerking, taken en veldmedewerkers bij beëindiging van Silve overgenomen door Probos en Borgman Beheer Advies), Probos (gegevensverwerking), Bureau Wim Daamen (softwareprogrammering en veldwerkcontroles, later overgenomen door WEnR), Borgman Beheer Advies (veldopnames, overgenomen taak van Bureau Silve) en Bureau Van Nierop (veldopnames).

De taakverdeling bij de NBI-7 is als volgt:

Ministerie van LNV: Opdrachtgever, deelname begeleidingsgroep

Wageningen Environmental Research: Algemene projectcoördinatie, handleiding veldopnames, veldwerkcontroles, rapportage naar opdrachtgever

Stichting Probos: Regelen van toestemming voor betreden terreinen voor metingen van steekproefcirkels; opzet en onderhoud database; verwerking van ruwe data tot basistabellen; berekening volumes, bijgroei en oogst (deels bureau Silve)

Borgman Beheer Advies: Uitvoering veldwerk, aanlevering ruwe data (deels bureau Silve)

Bureau Van Nierop: Uitvoering veldwerk, aanlevering ruwe data

Uit gesprekken met betrokkenen kwam naar voren dat het projectteam naar tevredenheid samenwerkt. Verantwoordelijkheden zijn duidelijk belegd en de samenwerking verloopt efficiënt.

\subsubsection{Verantwoording van methoden en resultaten, controle en feedback}

In essentie is de steekproefopzet adequaat en betrouwbaar, evenals de gegevenswerking en interpretatie. Naar het zich laat aanzien zal NBI-7, net als de voorganger NBI-6 een goed beeld geven van het Nederlandse bos.

Voor het afstemmen van meetmethodes, volgen en toepassen van protocollen is een heldere instructie van groot belang, evenals het regelmatig ijken van waarnemingen. Ook controle van metingen en terugkoppeling van bevindingen daarbij is belangrijk voor het garanderen van consistentie in de opgenomen gegevens. Dit is temeer van belang omdat gewerkt wordt met meetploegen die hun eigen regio's inventariseren. Alleen met een eenduidige interpretatie van instructies en gelijke uitvoering kan worden voorkomen dat er systematische verschillen in opnames ontstaan. Hierover is door meerdere personen zorg geuit.

In principe vindt er ieder jaar een velddag plaats met alle veldmedewerkers. Dit is in 2020 en 2021 komen te vervallen vanwege Covid-19, en in 2021 vervangen door een online bijeenkomst aan de hand van praktijksituaties. Voor kwaliteitsborging is het noodzakelijk de gemeenschappelijke instructies in het veld zo snel mogelijk weer op te pakken. Verdere afstemming is mogelijk door de huidige meetploegen jaarlijks een dag samen te laten oplopen (kijken bij de buren). 
Een deel van de opnames wordt achteraf gecontroleerd door WEnR (Mart-Jan Schelhaas). Opnemers worden uitgebreid ingelicht over de bevindingen van de controle, en eventuele aandachtspunten worden besproken. Eventuele meetfouten worden bij de controle direct aangepast in de database. Voor zover kon worden achterhaald worden metingen slechts zeer incidenteel afgekeurd, opnemers geven aan dat het echter niet altijd duidelijk is waarom plots zijn afgekeurd. De criteria die worden gehanteerd voor het afkeuren van een opname zijn niet vastgelegd. Het is van belang om dit te verduidelijken in het meetprotocol, opdat ook een derde partij tot eenzelfde beoordeling van de kwaliteit van het meetwerk kan komen.

\subsubsection{Kosteneffectiviteit}

De kosteneffectiviteit van de NBI hangt af van het aantal steekproefpunten, de opgenomen variabelen, de gebruikte methoden, organisatie en efficiëntie van veldwerk en gegevensverwerking. De mate waarin de huidige bosinventarisatie kosteneffectief is, is nauwelijks goed gefundeerd te beantwoorden.

Om toch een indruk te krijgen zijn de totale kosten van de inventarisaties in Vlaanderen, Noordrijn-Westfalen, en Nederland vergeleken. De kosten van de NBI-7 bedragen conform de begroting in totaal over de looptijd van 5 jaar, ongeveer k€ 870 . Dit komt feitelijk neer op $\mathbf{C} \mathbf{2 , 3 5}$ per hectare voor een volledige omloop van 5 jaar.

De kosten van de $1^{\mathrm{e}}$ Vlaamse bosinventarisatie bedroegen $k € 1.500$ voor de eerste inventarisatie (1997-1999, inclusief bodembemonstering en -analyse, zie Waterinx \& Roelandt, 2001), $k € 930$ voor de $2^{\mathrm{e}}$ bosinventarisatie (2009) en $k € 720$ voor de $3^{\mathrm{e}}$ Bosinventarisatie (Govaere, 2020; Govaere \& Leyman, 2020). Bij een bosareaal in Vlaanderen van 140.000 ha, met 2700 steekproefpunten, betekent dit $\mathbf{C} \mathbf{1 0 . 7 0}$ per ha voor VBI-1, $\mathbf{C} 6.60$ per ha voor VBI-2, en $\mathbf{C} \mathbf{5 , 1 0}$ per ha voor VBI-3 voor een 10 jarige periode, waarbij er bij de VBI-1 tevens bodemmonsters zijn verzameld, en tijdens VBI-1, VBI-2 en VBI-3 tevens vegetatieopnames zijn gedaan. Het aantal steekproefpunten in Vlaanderen is het dubbele per eenheid van oppervlak in vergelijking met Nederland en Noordrijn-Westfalen, om rekening te houden met de sterke versnippering.

Voor de Landeswaldinventur Noordrijn-Westfalen, met een bosoppervlak van 935.000 ha, en 9.300 steekproefpunten in een 10-jaarlijkse cyclus, bedroegen de kosten naar schatting $k € 1.395$ ( $€ 100$ per trakthoek/steekproefpunt uitbesteed veldwerk, $+€ 50$ organisatie en dataverwerking per trakthoek met eigen personeel - N.B. zeer ruwe schatting) d.w.z. $\mathbf{C}$ 1,50 per ha in een 10-jaarlijkse cyclus. Daarbij zijn de kosten van de gegevensverwerking in NRW relatief gering ( $€ 25.000$ per jaar) door de uitbesteding aan het Von Thünen instituut die dit voor geheel Duitsland uitvoeren in een vergaand gestandaardiseerde procedure. De toerekening van totale kosten voor de Landeswaldinventur NRW is niet goed mogelijk door het ontbreken van een integrale kostprijsschatting bij de inzet van eigen personeel, en voorgaande schatting is met de nodige prudentie te interpreteren.

Bij het aantal opnames per dag is voor NBI-7 in de planning uitgegaan van een gemiddelde van 7 steekproefpunten per dag voor een individuele veldmedewerker. De 
veldwerkers geven aan dat met de voorbereiding erbij dit eerder 6 dan 7 steekproefpunten per dag zijn. In Noordrijn-Westfalen wordt uitgegaan van 8 steekproefpunten (trakthoeken) per dag voor een ploeg van 2 personen; daarbij wordt de organisatie en de voorbereiding van het veldwerk gedaan door de vaste medewerkers van de Landesbetrieb Wald und Holz NRW. In Vlaanderen wordt uitgegaan van 2-3 opnames per dag, voor een individuele veldmedewerker (in de eerdere bosinventarisaties werd in ploegen van 3-4 personen gewerkt, waarbij 7 steekproefpunten per dag bemonsterd werden). Van de bestede tijd wordt in Vlaanderen naar schatting $60-70 \%$ besteed aan de bosopstand, en 30-40\% aan de vegetatie-opname. Rekening houdend met enigszins andere omstandigheden in zowel NRW als in Vlaanderen, lijkt de uitvoering van het veldwerk in Nederland naar verhouding efficiënt te verlopen (uitgedrukt in plots per dag per veldmedewerker).

De vergelijking van de kosten van bemonstering met Vlaanderen en NoordrijnWestfalen is moeilijk vanwege de verschillende kostenstructuur. In combinatie met de hierboven geconstateerde efficiëntie van het veldwerk kan geconstateerd worden dat er bij de steekproefopname van NBI-7 sprake is van reële kosten, en lijkt het onwaarschijnlijk dat er hier veel efficiencywinst te behalen is.

\subsubsection{Continue inventarisatie met jaarlijkse rapportage in NBI-8}

In de huidige opzet worden alle steekproefpunten binnen enkele jaren gemeten en vervolgens verwerkt tot een vijfjaarlijkse rapportage die de stand van zaken weergeeft op basis van de deze gegevens. Elk steekproefpunt wordt om de vijf jaar hermeten. Ter verdeling van de meetinspanning en garantie van de continuïteit in expertise is het voornemen om in 2022, met ingang van NBI-8, jaarlijks $20 \%$ van de steekproefpunten op te nemen, en steeds te rapporteren over de afgelopen vijf jaar, in een voortdurend meetprogramma. Om bias te voorkomen dient hierbij gewaarborgd te worden dat er geen systematische fouten optreden bijvoorbeeld door oververtegenwoordiging van regio's of bostypen in een bepaald jaar. Evalueer daarom de huidige indeling in opnamejaren om bias uit te sluiten en ervoor te zorgen dat iedere jaarlijkse opname representatief is voor het hele bosareaal.

Per jaar zou vervolgens kunnen worden volstaan met een basisrapportage, met eens per vijf jaar een volledige rapportage, bijvoorbeeld in samenhang met de LULUCF rapportage, zodat mutaties in het bosareaal en veranderingen daarbinnen tegelijkertijd kunnen worden gepubliceerd.

\subsection{Constateringen en aanbevelingen}

De NBI steekproefopzet is adequaat en betrouwbaar, evenals de gegevenswerking. De NBI geeft een goed beeld van het Nederlandse bos. Het veldwerk is efficiënt ingericht en verloopt goed, en de samenwerking tussen de partners verloopt efficiënt.

Bij toename van het aandeel gemengde opstanden wordt het onlogisch om als eerste criterium uit te gaan van de hoofdboomsoort van een opstand. Alhoewel voor het overgrote deel van het Nederlandse bos nog steeds mogelijk is om een kiemjaar aan te geven is er in toenemende mate sprake van ongelijkjarige, spontane menging, en een 
complexere bosstructuur. Deze ontwikkeling wordt verder gestimuleerd in de Bossenstrategie.

Aanbeveling: zorg in NBI-8 voor voldoende differentiatie in de categorieën van hoofdboomsoorten zodanig dat de feitelijke samenstelling van het Nederlandse bos goed weergegeven wordt, bijvoorbeeld door het toevoegen van een aantal categorieën onder de noemer hoofdboomsoort voor gemengd bos.

Naast de monitoring van het bosareaal en het voorkomen van kapvlaktes in de NBI, bestaat per provincie een apart systeem voor registratie van kapmeldingen en ontbossingen. In principe gaat dit over de zelfde informatie. Dit roept de vraag op in hoeverre deze verschillende registraties op elkaar aansluiten, en of harmonisatie hiervan tussen provincies kan leiden tot een beter inzicht in de dynamiek van het Nederlandse bos.

Aanbeveling: onderzoek de wenselijkheid om de registratie van kapmeldingen en ontbossing zodanig in te richten dat dit aansluit op, en vergelijkbaar wordt met de inventarisatie van kapvlaktes en schaal van verjonging uit de bosinventarisatie. Dit is vooral een taak van de provincies, verantwoordelijk voor de registratie van de kapmeldingen, maar zou moeten worden afgestemd met de NBI.

De verandering in bossamenstelling leidt tot heroverweging van de steekproeftechniek. Door de meer gevarieerde bossamenstelling, en het kleinschalig voorkomen van verjonging wordt het werken met variabele steekproefcirkels problematisch. Bij het voorkomen van veel verjonging wordt daardoor het aandeel oude opstand te laag, terwijl de bomen die in eerdere opnames meegenomen zijn, feitelijk toch moeten worden gemeten.

Aanbeveling: ga bij NBI-8 over op vaste steekproefcirkels, gerelateerd aan de stamomvang van de bomen (zoals in de Vlaamse aanpak) met waarborging van de continuïteit van eerdere opnames.

Voor het correct berekenen van de boomvolumes moet een eenduidige set van parameters voor de volumefuncties worden gebruikt; de huidige set is niet consistent.

Aanbeveling: ontwikkel voor NBI-8 een correcte, consistente lijst met volumefuncties voor de afzonderlijke soorten. Onderzoek de mogelijkheden om via LIDAR technieken nieuwe volumefuncties te ontwikkelen. Gebruik bij vergelijking tussen jaren eenzelfde set parameters voor het volumetarief.

De schatting van dood hout is in NBI-7 gebaseerd op stamhout dat gerelateerd kan worden aan stamvoeten binnen de steekproefcirkel. Dit geeft mogelijk een onderschatting omdat bijvoorbeeld losliggend takhout hiermee niet wordt gemeten.

Aanbeveling: stap over op line-intersect sampling waarbij dood hout rechtstreeks bemonsterd kan worden, los van de oorsprong (zie: werkwijze Vlaamse inventarisatie), met waarborg van continuïteit van eerdere opnames.

Betreffende de toestemming voor het veldwerk: voor een deel van de opnames blijkt het niet mogelijk om met de huidige werkwijze vooraf toestemming te verkrijgen voor het uitvoeren van het veldwerk. Als gevolg daarvan worden veldopnemers teveel belast met het nabellen voor toegang, wat ten koste gaat van de efficiency.

Aanbeveling: intensiveer de werkwijze en maak voldoende budget vrij voor extra inzet om toestemming voor de opname van steekproefpunten te verkrijgen. 
Bij de uitvoering van het veldwerk kunnen incidenteel veiligheidsaspecten in het geding komen, bijvoorbeeld in de nabijheid van (snel)wegen door het verstoren van wild in het bos (reeën), of in de nabijheid van spoorlijnen.

Aanbeveling: neem een veiligheidsinstructie op in de veldinstructie, zodat het voor de veldmedewerkers duidelijk is wat wel en niet is toegestaan, en hoe te handelen is om de gewenste veiligheid te waarborgen.

Kwaliteitsborging van zowel veldopname als gegevensverwerking is essentieel voor de betrouwbaarheid van de resultaten. Nu wordt de inventarisatie in het zuiden van het land (ten zuiden van de grote rivieren) uitgevoerd door een andere ploeg dan in het noorden van het land. Een goede afstemming is noodzakelijk om regionale bias te voorkomen.

Aanbeveling: besteed voortdurend zorg aan standaardiseren en toetsing van veldwerk door verschillende veldmedewerkers; Geef daarbij heldere criteria op basis waarvan goedkeuring of afkeuring van metingen plaats vindt zodat ook derden deze controle in een onafhankelijke steekproef kunnen uitvoeren.

Niet alle opgenomen variabelen in de huidige steekproef zijn relevant of voldoende eenduidig gedefinieerd. Daarnaast kan overwogen worden het aantal op te nemen variabelen uit te breiden. De volgende aanbevelingen worden in de tekst gedaan:

Aanbevelingen:

- Zie af van de opname van de stamkwaliteit van individuele bomen in NBI-8.

- Zowel de verstoringen door beheer als de natuurlijke verstoringen (brand, droogte, windworp, insecten, etc.), en vitaliteit moeten beter gedefinieerd worden zodat dit nauwkeurig kan worden opgenomen.

- Opname van extra informatie over soortgroepen anders dan bomen en struiken wordt afgeraden

- Opname van bodemparameters (organische stofgehalte en koolstofvoorraden is dringend gewenst, maar hiertoe zou een apart meetprotocol moeten worden gevolgd. Daarbij kan wel worden aangesloten bij het steekproefnetwerk.

Naar aanleiding van het eerder beschreven overzicht van remote sensing toepassingen, is er geen directe aanleiding om de huidige methode te wijzigen. Toekomstige ontwikkelingen kunnen mogelijk snel verandering brengen.

Aanbevelingen:

- Organiseer een pilot naar het gebruik van MLS binnen de huidige meetopzet. Door bij een aantal plotopnames direct MLS opnames te maken en daarbij niet enkel de data te analyseren, maar juist ook te kijken naar gebruiksgemak, tijd en kosten wordt duidelijk of met de huidige stand van de techniek het gebruik van deze techniek haalbaar wordt, of nog steeds te weinig oplevert.

- Blijf inventariseren wat de mogelijkheden zijn van andere remote sensing methodes die gebruikt kunnen worden om (veranderingen in) het gehele bosareaal te monitoren. Een aantal voorbeelden zijn hiervoor genoemd.

Het huidige netwerk van steekproefpunten wordt eens per 5 jaar opgemeten, zodat de rapportage synchroon loopt met de LULUCF rapportage. Dit leidt tot hogere kosten in vergelijking met een meetcyclus van 10 jaar zoals in Vlaanderen en NoordrijnWestfalen. Een herhaalde meting van de steekproefpunten om de vijf jaar, in een 
continue systeem, heeft als voordeel dat boommortaliteit en dunning beter kunnen $\mathrm{n}$ worden gemonitord, en dat in de uitvoering de expertise behouden en gecontinueerd wordt.

Aanbeveling: Handhaaf de huidige 5-jaarlijkse cyclus in een continue systeem zoals voorgesteld voor NBI-8. 


\section{$4 \quad$ Aansluiting bij ontwikkelingen in beheer en beleid}

Het Nederlandse bos wordt intensief gebruikt, en het bosbeheer is voortdurend in ontwikkeling als reactie op veranderende maatschappelijke vraag naar verschillende bosfuncties. Dit leidt enerzijds tot planningsvraagstukken: welk bos hebben we nu, en waar zijn welke ingrepen wenselijk om de functievervulling te optimaliseren? Anderzijds leidt dit tot beleidsoverwegingen: hoe willen we het Nederlandse bos verder ontwikkelen om ook in de toekomst aan de vraag naar verschillende bosfuncties te kunnen voldoen? Een belangrijke beleidsoverweging is daarbij welke combinatie van functies wenselijk is, en waar de nadruk moet liggen, rekening houdend met het ontwikkelingspotentieel van het bos en de vraag naar producten en diensten nu en in de toekomst. Ten behoeve van zowel beheer als beleid is goed inzicht in de huidige toestand van het Nederlandse bos wenselijk. Ten behoeve van de actuele en toekomstige functievervulling is daarbij tevens inzicht nodig in groei en vitaliteit van het bos.

De NBI-7 richt zich op het Nederlandse bos als geheel, en heeft daarmee vooral nationale relevantie. Het bosbeleid wordt daarnaast in belangrijke mate ingevuld door de provincies en het is daarom wenselijk om inzicht te krijgen in de behoefte aan bosinformatie op provinciaal niveau. Bij de uitvoering van NBI-7 was voor de winter $2020 / 2021$ een vraagarticulatie van gebruikersgroepen voorzien, die echter nog niet is uitgevoerd. De vraagarticulatie is vooral ingegeven door de Bossenstrategie van Ministerie en provincies, die in 2020 gepubliceerd is. De Bossenstrategie stelt beleidswijzigingen ten aanzien van het beheer en functievervulling van het bestaande bos voor (meer aandacht voor biodiversiteit en koolstofvastlegging, revitalisering, nadruk op kleinschalig beheer), en omvat daarnaast een bosuitbreidingsdoelstelling van $10 \%$ in de komende 10 jaar, d.w.z. zo'n 37.000 ha. Deze onderwerpen en hun mogelijke relevantie voor NBI-8 worden in het navolgende kort besproken,

Naast de nationale informatiebehoefte is er een aantal bestaande internationale rapportage verplichtingen waarvoor de NBI de basisgegevens levert. Op Europees vlak ontstaat er mogelijk de komende jaren een aanvullende informatiebehoefte samenhangend met o.a. de Green Deal van de Europese Commissie, het streven naar een circulaire economie, etc.

Uitvoering van het natuurbeleid is nu vooral bij de provincies belegd. De steekproef van de NBI is echter niet geschikt voor rapportage van resultaten per provincie, behoudens wellicht de meest bosrijke provincies zoals Gelderland, Drenthe en Noord-Brabant. De betrouwbaarheid zal te laag zijn gezien het lage aantal steekproefpunten voor de bosarme provincies. Resultaten met betrekking tot het bosareaal kunnen wel per provincie worden weergegeven, zoals ook in de rapportages van de verschillende NBI's is gebeurd. 


\subsection{Bosuitbreiding}

Het vaststellen van het juiste bosareaal is vanaf het allereerste begin een centrale doelstelling van de Nederlandse bosinventarisaties geweest. De afgelopen jaren is hier regelmatig discussie en onduidelijkheid over geweest, onder andere samenhangend met de onduidelijkheid over de gebruikte basiskaart (zie de opmerkingen dienaangaande in paragraaf 3.1). Gezien de Nederlandse ambitie voor bosuitbreiding zoals neergelegd in de Bossenstrategie van Rijk en provincies, ontstaat er een concrete, nieuwe informatiebehoefte, zowel op nationaal als provinciaal niveau aangaande de feitelijk gerealiseerde bosuitbreiding. Dit betekent dat in NBI-8 een heldere procedure ingebouwd moet worden waarmee deze bosuitbreiding gemonitord kan worden. Een mogelijk probleem daarbij is het gegeven dat nieuw aangelegd bos pas na enkele jaren feitelijk als bos wordt waargenomen en als zodanig wordt geïdentificeerd op de basiskaart die wordt gebruikt voor het vaststellen van de NBI steekproefpunten. Dat zou betekenen dat de waargenomen bosuitbreiding feitelijk achterloopt bij de in gang gezette bosuitbreiding. Mogelijk kan dit worden voorkomen door de uitgevoerde bosuitbreiding apart te registreren en vervolgens aan de basiskaart toe te voegen.

Om verschillende redenen (Bossenstrategie, LULUCF rapportage) is er interesse voor inventarisatie van kleine bosjes (0,1-0,5 ha) en opname daarvan in NBI-8. Voor de LULUCF kaart worden kleine bosjes van 0,0625 tot 0,5 ha op dit moment meegenomen als "trees outside forests". Hun totale oppervlakte is daarmee bekend, maar de kenmerken van deze kleine bosjes blijven buiten beeld (en wordt aangenomen dat deze kenmerken gelijk zijn aan het gemiddelde van het totale Nederlandse bos). De voorgenomen bosuitbreiding zal voor een deel worden gerealiseerd door aanplant van landschapselementen in het buitengebied, waardoor in feite veel nieuwe kleine bosjes ontstaan en hun aandeel in het gehele bosareaal zal toenemen.

Het is wenselijk de kenmerken van deze kleine bosjes mee te nemen in de inventarisatie en dus de steekproefname uit te breiden. Daarbij zou voor het bepalen van de ondergrens van het oppervlakte de definitie van de houtopstand uit de Wet natuurbescherming kunnen worden aangehouden, namelijk 0,1 hectare. Daarbij is het van groot belang om de continuïteit van de NBI te waarborgen door deze kleine bosjes duidelijk te onderscheiden van de overige (in het verleden opgenomen) steekproefpunten.

\subsection{Biodiversiteit, koolstofvastlegging en kleinschalig beheer}

De achtergrond van de nationale bosinventarisatie was voorheen sterk gericht op houtvoorraad en houtproductie, maar is geleidelijk verbreed bij de ontwikkeling van het meetnet functievervulling (Dirkse et al., 2003). Ten behoeve van de evaluatie van resultaten van verschuivingen in het bosbeleid bijvoorbeeld richting biodiversiteit en koolstofvastlegging, komen hier nieuwe vormen van datagebruik en toepassing van de NBI resultaten bij. Dit wordt benadrukt door de nieuwe Bossenstrategie waar sprake is van een verschuiving in doelstelling aangaande bosfuncties in het bestaande bos, bijvoorbeeld richting meer biodiversiteit, koolstofvastlegging en kleinschalig beheer. 
Samen met de nagestreefde bosuitbreiding stelt dit aanvullende eisen aan de landelijke bosinventarisatie.

De NBI levert essentiële gegevens ten behoeve van het Nederlandse bosbeleid en geeft goed inzicht in de samenstelling en groei van het Nederlandse bos. Daarbij draagt de NBI sporen van de nadruk op oogst en productie van hout in het verleden, waardoor er geen of nauwelijks conclusies over de ontwikkeling van bosfuncties die niet samenhangen met houtvoorraad te trekken zijn. Dit geldt bijvoorbeeld voor biodiversiteit. Voor wat betreft koolstofvastlegging geldt dit niet of veel minder, aangezien de totale koolstofvoorraad in de biomassa goed valt af te leiden uit de houtvoorraad. Daarbij moet worden opgemerkt dat de koolstofvoorraad in het totale ecosysteem voor meer dan $50 \%$ bepaald wordt door de organische stof in en op de bodem, en dit is een variabele die tot dusverre niet is meegenomen, afgezien van de inventarisatie van de strooisellaag.

\subsubsection{Biodiversiteit}

Ten behoeve van de rapportage voor de Habitatrichtlijn is door de begeleidingscommissie (vergadering 4 juni 2019) gesuggereerd om inventarisatieplots toe te voegen teneinde ook over de minder vaak voorkomende bostypen te kunnen rapporteren (voor slechts 2 habitattypen zijn voldoende punten in de NBI vertegenwoordigd). Dit zou echter leiden tot verstoring van de huidige steekproefopzet, hetgeen onwenselijk is. Het is daarom beter om de inventarisatie voor de habitatrichtlijn los te zien van de NBI, zodanig dat er geen verstoring van het bemonsteringsschema optreedt. In plaats daarvan lijkt het logischer om ten behoeve van de Habitatrichtlijn aan te sluiten bij andere monitoringsnetwerken zoals SNL of een monitoringsnetwerk dat geheel is toegesneden op kwaliteitskenmerken van de habitattypen.

In het MFV werd per steekproefpunt een vegetatieopname gemaakt. Ook in de Vlaamse bosinventarisatie wordt een volledige vegetatieopname gemaakt per plot. Opname van de vegetatie levert extra informatie over het voorkomen van plantensoorten in het Nederlandse bos en dus een breder inzicht in de diversiteit opleveren dan de huidige gegevens over de houtige soorten. Opname van de vegetatie per steekproefpunt levert echter nauwelijks inzicht in de ontwikkelingen van populaties van soorten die indicatief zijn voor de kwaliteit van de verschillende bosecosystemen, simpelweg omdat de trefkans van deze soorten te klein is. Dit levert niet de benodigde informatie over ontwikkeling van beleidsrelevante biodiversiteit in het Nederlandse bos, en staat niet in verhouding tot de extra kosten die hiervoor gemaakt moeten worden (zie ook 3.2.1 en 3.4.3).

Voor de rol van bossen in de biodiversiteit van Nederland is vooral de aanwezigheid van dood hout en dikke, oude en aftakelende bomen van belang. De aanwezigheid van deze elementen kan als goede proxy gelden voor de (potentiele) aanwezigheid van soorten die aan deze substraten gebonden zijn. Voor een betere schatting van het liggende dode hout is reeds geadviseerd over te gaan op line intersect sampling (zie 3.2.1). 


\subsubsection{Koolstofvastlegging}

Binnen de klimaatenvelop worden bodemkoolstofbepalingen gedaan, waarbij is uitgaan van de NBI steekproefpunten. Voorlopig zijn dit additionele projecten die zo goed mogelijk aansluiten bij de NBI infrastructuur. Er zijn op dit moment geen plannen om dit binnen de NBI-8 te gaan integreren. Door de grote ruimtelijke variabiliteit van organische stof en bodemkoolstof vraagt de bemonstering daarvan een substantieel aantal monsters per plot. Daarbij heeft een 5 -jaarlijkse meting van bodemkoolstof weinig zin gezien de traagheid van verandering in bodemkoolstof. Los daarvan blijft het onverkort relevant om te weten hoeveel bodemkoolstof is opgeslagen in het Nederlandse bos, en of deze hoeveelheid toe- dan wel afneemt door beheer.

De koolstofvoorraden en andere relevante bodemparameters zouden echter wel goed in kaart gebracht kunnen worden door een gestandaardiseerde profielbeschrijving te maken per steekproefpunt. Dergelijke profielbeschrijvingen maken het mogelijk betrouwbare informatie over verschillende bodemkenmerken te genereren. Opname van deze beschrijvingen in de basisregistratie ondergrond (BRO) waarborgt de benodigde kwaliteit van de profielbeschrijvingen.

Voor bepaling van de meer dynamische koolstofvoorraad in de humuslaag wordt nu per opname een meting gedaan van de humuslaag. Omdat deze humusvoorraad sterk afhankelijk is van de lokale bosontwikkelingsfase, soortensamenstelling, bosleeftijd en opgetreden verstoringen is het van belang deze humusdikte ook regelmatig te blijven opnemen (in tegenstelling tot de profielbeschrijving die eenmalig is).

\subsubsection{Kleinschalig beheer}

Het bosbeheer in Nederland ontwikkelt zich in de richting van kleinschaliger beheer, onder verschillende noemers zoals Pro Silva beheer, geïntegreerd bosbeheer, multifunctioneel bosbeheer, en natuurvolgend bosbeheer. Deze beheervormen hebben verschillende accenten, maar steeds is er aandacht voor spontane verjonging, gemengd bos, dood hout, en een min of meer kleinschalige en afwisselende bosstructuur. De Bossenstrategie onderstreept deze ontwikkeling.

In NBI-6 is voor de permanente steekproefpunten het soort kap opgenomen, met onderscheid naar vlaktegewijze kap (zowel klein- als grootschalig), individuele kap (inclusief dunning), en geen kapactiviteit, met het oogmerk om een vergelijking te kunnen maken met de eerder opname als onderdeel van het Meetnet Functievervulling 10 jaar eerder. Dit is in NBI-7 niet meer op deze wijze opgenomen, in NBI-7 wordt alleen gemeld of er sprake is van oogst sinds de vorige opname, zonder nadere aanduiding van schaal of intensiteit.

Gezien de maatschappelijke commotie over de gewenste schaal van ingrijpen in het Nederlandse bos, en de beperkte provinciale registratie van de kapmeldingen, is het wenselijk om hier bij de NBI-8 helderheid te verschaffen, door de registratie van voorkomen en schaal van vlaktekap op de steekproefpunten enerzijds, en door standaardisatie van de registratie van kapmeldingen bij de provincie anderzijds, zodanig dat beide bronnen vergelijkbaar worden. 
Er wordt hier aanbevolen om bij de opname van de steekproefpunten weer over te gaan tot het registreren of, en op welke schaal, vlaktegewijze verjongingsmaatregelen zijn uitgevoerd.

\subsection{Internationale rapportage verplichtingen}

- NBI-6 en NBI-7 zijn sterk gedreven door de internationale rapportage verplichtingen voortvloeiend uit het klimaatbeleid, met name:UNFCCC rapportage (volledige rapportage t.b.v. de klimaatconventie, zie Hoofdstuk 6 in de NIR (Ruyssenaars et al., 2021), methode in Arets et al. 2021).

- Kyoto protocol rapportage (boekhouding 1e commitment periode 2008-2012, tweede commitment periode 2013-2020 onder het Kyoto Protocol, zie Hoofdstuk 11 in de NIR (Ruyssenaars et al., 2021 tabellen 'NIR1' t/m 'accounting' in de CRF tabellen, methode in Arets et al. (2021).

- EU besluit 529/2013[1] (aanvulling op de Kyoto Protocol rapportage, beschrijving en methode in afzonderlijke annex bij de NIR en cijfers in aanvullende Excel tabellen).

- EU LULUCF verordening 841/2018 (nieuwe boekhoudregels voor periode 2021-2025 en 2026-2030 onder het klimaatakkoord van Parijs).

Daarnaast wordt de informatie uit de NBI ook gebruikt voor de jaarlijkse rapportages aan de FAO (o.a. ten behoeve van het vijfjaarlijkse Forest Resource Assessment en de FAOSTAT database) en de UNECE.

Naar het zich laat aanzien zijn er vooralsnog geen wijzigingen nodig naar aanleiding van de LULUCF eisen aangaande de berekeningen voor het Forest Reference Level voor de LULUCF rapportage (informatie Eric Arets / Mart-Jan Schelhaas)

Naast de huidige verplichtingen zullen uit een aantal recente beleidsinitiatieven naar verwachting nieuwe rapportageverplichtingen voortkomen waarvoor de gegevens uit de bosstatistiek nodig zijn. Naar alle waarschijnlijkheid betreft dit grotendeels informatie die reeds is vervat in NBI-7 / NBI-8, maar wellicht vloeien nieuwe eisen voort uit nieuw beleid. Relevant in dezen zijn vooral Europese rapportages over de ontwikkelingen in het monitoren van biodiversiteit, samenhangend met de EU biodiversiteitsstrategie (met specifieke aandacht voor de bescherming van primaire en oude bossen), de Green Deal, en de Europese Bossenstrategie. De EU Bossenstrategie moet nog worden uitgebracht, en hangt samen met de EU Biodiversiteitsstrategie. Een centraal aspect daarin zal het areaal natuurbos zijn, en tevens de beheervorm van het overige, multifunctionele bos. Voor de NBI-8 betekent dit mogelijk dat de categorie natuurbos goed identificeerbaar moet zijn, evenals de beheervorm van het overige bos. Dit kan door koppeling met de provinciale natuurbeheerkaarten.

De aanstaande Europese Bossenstrategie zal mogelijk ook regels en doelen omvatten over bosgebruik en bio-energie. Dit heeft echter meer betrekking op de productketen, dan op de monitoring van de hulpbron zelf. Het is wel denkbaar dat het meer dan voorheen wenselijk is om oogst en gebruik van brandhout uit het Nederlandse bos inzichtelijk te krijgen. Mogelijk ligt dit niet op weg van de NBI, daar dit een specifiek onderdeel van het bosgebruik en de productketen is, maar net als de huidige analyse 
van houtoogst zou dit congruent moeten zijn met de aanwas- en oogstschattingen van de NBI.

\subsection{Constateringen en aanbevelingen}

Op nationaal niveau hadden NBI-6 en NBI-7 weinig urgentie in de informatiebehoefte, niet in de laatste plaats omdat de overheid nauwelijks beleid voerde op bossen. Dit is recent veranderd met de publicatie van de Nederlandse Bossenstrategie. Dit beleidsvoornemen heeft bossen nadrukkelijk voor het voetlicht gebracht, en genereert een aantal nieuwe vragen waarop de bosstatistiek antwoord kan of zou moeten geven. Dit geldt met name op het vlak van bosbeheer, biodiversiteit en bosuitbreiding. Ook vanuit het klimaatakkoord is behoefte aan inzicht over ontwikkelingen in onder andere koolstofvoorraden en bosareaal. Zo is er op dit moment geen goed inzicht in de hoeveelheid bos die wordt omgevormd naar andere landgebruiksvormen of natuurtypen, of in de schaal van bosverjonging (zie o.a. den Ouden \& Mohren 2020). Los van het gebruik van NBI gegevens ten behoeve van nationaal beleid is er sprake van een divers gebruik van de NBI resultaten in onderzoek en praktijk.

De biodiversiteitsdoelen zijn door de Bossenstrategie nadrukkelijker op de voorgrond komen te staan. De NBI geeft als een van de weinige meetnetten een werkelijk representatief beeld van de Nederlandse diversiteit, in dit geval voor houtige soorten. Uitbreiding van de NBI met informatie over andere soortgroepen ligt echter niet voor de hand, omdat de trefkans van zeldzame soorten erg klein is (en daarmee de betrouwbaarheid van geconstateerde veranderingen erg laag) en de meeste soortgroepen erg specialistische kennis vereisen. Het lijkt daarom beter om monitoring van de toestand van het bos zoals in NBI-6 en NBI-7 gescheiden te houden van de meeste andere meetnetten.

Aanbeveling: Het is op dit moment niet nodig noch effectief om de NBI verder uit te breiden ten behoeve van soortgroepen anders dan houtige soorten. Dood hout, aanwezigheid van dikke bomen en boomsoortensamenstelling zoals nu opgenomen in de NBI, vormen reeds bruikbare proxies voor monitoring van biodiversiteit in bossen.

Koolstofopslag en koolstofvastlegging in de biomassa is goed te kwantificeren op basis van de boskenmerken die onderdeel zijn van de huidige NBI. Daar meer dan de helft van de koolstofvoorraad in het bosecosysteem is opgeslagen in de bodem, is het wenselijk om ook de hoeveelheid koolstof in de bodem te weten. Via humusmetingen wordt de dynamische strooisellaag reeds vijfjaarlijks bemonsterd. Uitbreiding met informatie over bodemkenmerken van de minerale bodem is zeer gewenst, maar kan met een lagere meetfrequentie worden uitgevoerd.

Aanbeveling: Leg de bodemkenmerken vast via gestandaardiseerde profielbeschrijvingen per steekproefpunt, gekoppeld aan de basisregistratie ondergrond (BRO). Bemonster bodemkoolstof (organische stofgehaltes) in een 10 -jarige cyclus of in een subset van het aantal steekproefpunten. 
Er is dringend behoefte aan betrouwbare gegevens over het voorkomen en de schaal van vlaktegewijze kap en verjonging.

Aanbeveling: Voeg een eenvoudige registratie van het optreden van kap, vlaktegewijs of individueel, en inclusief de omvang van de kapvlakte, toe aan de bemonstering, en stem dit af met de provinciale registratie van kapmeldingen zodat een consistent beeld ontstaat.

Naast de min of meer vanzelfsprekende toepassing van de NBI gegevens in onderzoek en praktijk, valt het op dat de NBI gegevens geen rol van betekenis lijken te spelen in het publieke debat over bos en bosbeheer in Nederland. Het is te overwegen om publieksinformatie verder te ontwikkelen als onderdeel van de implementatie van de Bossenstrategie van het Ministerie, met daarbij monitoring van het gebruik van de NBI gegevens in diverse toepassingen.

Aanbeveling: Zorg voor voldoende publieksvoorlichting op basis van NBI gegevens, en maak tevens het gebruik van NBI gegevensinzichtelijk. 


\section{Conclusies}

De zevende Nederlandse Bosinventarisatie (NBI-7) levert betrouwbare gegevens over de structuur en samenstelling van het Nederlandse bos, de groei en ontwikkeling van het bos, en de omvang en verandering van het Nederlandse bosareaal. De werkwijze is consistent met NBI-6 en NBI-7 geeft naar verwachting een goed beeld van het Nederlandse bos. De NBI gegevens komen tegemoet aan een uitgebreide en diverse vraag naar informatie over het Nederlandse bos, de nauwkeurigheid en kwaliteit van de gegevens is voldoende en geeft geen aanleiding tot ingrijpende heroverweging van opzet of methodes.

Voor het vergroten van de transparantie is het wel nodig om de gebruikte uitgangspunten, technieken en analysemethoden helder en eenduidig vast te leggen. Een aantal variabelen is nog niet helder gedefinieerd, en behoeven nadere uitwerking. Voor de statistische verwerking van de steekproef wordt een aantal aanbevelingen gedaan die verder technisch zijn uitgewerkt in de bijlagen. Belangrijkste aanbevelingen betreffen het overstappen van variabele steekproefcirkels naar vaste plotstralen en het verwerken van de steekproef als SPR (sampling with partial replacement) ontwerp.

De letterlijke basis van de steekproef, de bossenkaart, voldoet voor de steekproef. Door de resolutie te vergroten kunnen ook de kleinere boselementen in het landschap beter worden gemonitord.

De steekproef is efficiënt, en wordt met toereikende technische middelen uitgevoerd. Remote sensing technieken lijken veelbelovend voor de toekomst, maar zijn op dit moment nog niet toereikend om met eenzelfde precisie en detailniveau gegevens als in de huidige meetmethodes te schatten. De veldmetingen verlopen efficiënt en geven weinig aanleiding tot verdere suggesties voor verbetering; de verdere dataverwerking verloopt eveneens efficiënt, maar kan mogelijk nog verder worden geautomatiseerd. De dichtheid van het steekproefnetwerk is toereikend, en kan evenals de vijfjaarlijkse meetfrequentie gehandhaafd blijven. Uitbreiding van het steekproefnetwerk met opname van kleine $(<0,5$ hectare) bossen wordt aangeraden.

De meeste opgenomen meetvariabelen zijn relevant; alleen houtkwaliteit kan als variabele vervallen. De opname van dood hout zou moeten worden aangepast, en de karakterisering van de hoofdboomsoort zou kunnen worden uitgebreid met een aantal mengings-categorieën. Kenmerken en gevolgen van verstoringen dienen beter te worden gedefinieerd. Het steekproefnetwerk leent zich niet tot opname van biodiversiteitsaspecten anders dan die van houtige planten. Informatie over andere soortgroepen dient uit andere meetnetten te worden afgeleid. Voor het monitoren van koolstof dient de steekproef te worden aangevuld met informatie over de bodem.

Ten behoeve van de kwaliteitsbewaking en het actueel houden van meetmethodes en verwerkingstechnieken is het aan te bevelen om goed geïnformeerd te blijven aangaande benaderingen elders in Europa, bijvoorbeeld in ENFIN en COST. De mate waarin de kwaliteitsbewaking wordt uitgevoerd is niet duidelijk vastgelegd, en kan beter gedocumenteerd worden. 
De Nederlandse bosinventarisatie is een belangrijke basis voor discussie en gedachtenvorming. Het is daarom wenselijk om te zorgen voor goede en effectieve publieksvoorlichting. Daarbij is de vrije beschikbaarheid van de gegevens belangrijk voor de transparantie, en voor een breed gebruik van de NBI resultaten. 


\section{Literatuur}

Akerblom, M., P. Raumonen, R. Mäkipää \& M. Kaasalainen (2017). Automatic tree species recognition with quantitative structure models. Remote Sensing of Environment 191, 1-12.

Arets, E.J.M.M., J.W.H van der Kolk, G.M. Hengeveld, J.P. Lesschen, H. Kramer, P.J. Kuikman \& M.J. Schelhaas (2021). Greenhouse gas reporting of the LULUCF sector in the Netherlands. Methodological background, update 2021. Wageningen. WOt-technical report 201. $132 \mathrm{p}$.

Berkhout, A.H. (1920). Het meten der boomen in verband met hun aanwas (mit deutscher Zusammenfassung). Mededelingen van de Landbouwhogeschool Wageningen, Netherlands 17, 109225

BMEL (2011). Aufnahmeanweisung für die dritte Bundeswaldinventur (BWI³) (2011-2012). Bundesministerium für Ernährung und Landwirtschaft, 2. geänderte Auflage, $111 \mathrm{pp}$.

BMEL (2014). Der Wald in Deutschland. Ausgewählte Ergebnisse der dritten Bundeswaldinventur. Berlin, Bundesministerium für Ernährung und Landwirtschaft, 56 pp.

Bunschoten, L. (1987). Overzicht van de geschiedenis van de Nederlandse Bosstatistiek. Nederlands Bosbouw Tijdschrift 59: 76 -78.

Bucksch, A., R. Lindenbergh, M. Abd Rahman \& M. Menenti (2014). Breast Height Diameter Estimation From High-Density Airborne LiDAR Data. IEEE Geoscience and Remote Sensing Letters 11: 10561060.

Centraal Bureau voor de Statistiek (1985). De Nederlandse bosstatistiek, deel 1 de oppervlakte bos, 1980-1983. Dutch Biostatistics, Part 1, Forest Area 1980-1983. Staatsuitgeverij, 's-Gravenhage.

Cunia T. (1964). Weighted Least Squares Method and Construction of Volume Tables. Forest Science, 10: $180-191$.

Cunia, T. (1985). On the error of biomass estimates in forest inventories. Part 1. Its major components. Paper prepared for the National Forest Inventories in Europe Workshop, University of Freiburg Faculty of Forestry, Freiburg i.Br. German Federal Republic, 10-14 June, 1985.

Clerkx, S., M.-J. Schelhaas, R. de Waal, J. Oldenburger, H. Schoonderwoerd, W. Daamen \& D. Borgman (2017) Eindrapportage Vooronderzoek NBI7. Rapport WUR/Probos/Silve/Bureau Daamen/Borgman Beheer Advies.

Daamen, W.P. \& G.M. Dirkse (2010). Chapter 24: The Netherlands. In: E. Tomppo et al. (eds.), National Forest Inventories. Springer, p. 383-389.

Daamen, W.P. \& T.M. Ritskes (1987). Analyse van de wijzigingen in het Nederlandse bos in de periode 1968-1983. Nederlands Bosbouw Tijdschrift 59: 94-101.

Daamen, W.P., A.P.P.M. Clerkx \& M.J. Schelhaas (2017). Veldinstructie Zevende Nederlandse Bosinventarisatie (2017-2021). Wageningen, Wettelijke Onderzoekstaken Natuur \& Milieu, WUR. WOt-technical Report 101, 48 pp.

Daamen, W.P., A.P.P.M. Clerkx \& M.J. Schelhaas (2019). Veldinstructie Zevende Nederlandse Bosinventarisatie (2017-2021); Versie 2.0. Wageningen, Wettelijke Onderzoekstaken Natuur \& Milieu, WUR. WOt-technical report 151. $52 \mathrm{pp}$.

Daamen, W.P. \& H. Schoonderwoerd (1990). Bijgroeischatters voor individuele bomen in bosverband. Project "Houtooststatistiek en Prognose Oogstbaar Hout". Verwerking gegevens heropname steekproefpunten onderdeel bijgroei. In opdracht van Directie Bos- en Landschapsbouw, Afd. Statistiek. 30 mei 1990. Rapportserie nr. 10 Bureau Daamen \& Schoonderwoerd.

De Klein, J.P.G en J.J. Jansen (1992). Planning en controle in ongelijkjarig bos, Nederlands Bosbouwtijdschrift 64: 313-322.

De Vries, W., J.J. de Jong, J. Kros \& J.H. Spijker (2019). Het effect van houtoogst op nutriëntenbalansen in bossen op zandgronden. Onderbouwing van een adviessysteem. Wageningen, Wageningen Environmental Research, Rapport 2923, 78 pp.

De Vries, P.G. (1986) Sampling theory for forest inventory: a teach-yourself course. Springer Verlag.

Den Ouden, J \& G.M.J. Mohren, 2020. De ecologische aspecten van vlaktekap in het Nederlandse bos. Rapport voor het ministerie van LNV in het kader van de Bossenstrategie. Rapport Wageningen University, Wageningen, $63 \mathrm{pp}$. 
Dik, E.J. (1984). De schatting van het houtvolume van staande bomen van een aantal in de bosbouw gebruikte soorten. Uitvoerig verslag Rijksinstituut voor onderzoek in de bos- en landschapsbouw "De Dorschkamp" Band 19(1), Wageningen.

Dik, E.J. (1990). De schatting van volumes en werkhoutlengten bij populier. Rapport Instituut voor bosbouw en groenbeheer "De Dorschkamp" 590, Wageningen.

Dik, E.J. (1992). Een volume tabel voor zwarte els in Nederland. Wageningen, Instituut voor Bos- en Natuuronderzoek (IBN-DLO), Dorschkamp Rapport nr. 702, 26 pp.

Dirkse , G.M., W.P. Daamen \& C. Schuiling (2001). Toelichting bossenkaart. Alterra, Research Instituut voor de Groene Ruimte, Alterra-rapport 292, 88 pp.

Dirkse, GM, WP Daamen, H Schoonderwoerd en JM Paasman (2003). Meetnet Functievervulling bos Het Nederlandse bos 2001-2002. Rapport EC-LNV nr. 2003/231

Dirkse, G.M., W.P. Daamen, H. Schoonderwoerd, M. Japink, M. van Jole, R. van Moorsel, P. Schnitger W.J. Stouthamer \& M. Vocks (2007). Meetnet Functievervulling bos 2001-2005. Vijfde Nederlandse Bosstatistiek. Directie Kennis, Ministerie van Landbouw, Natuur en Voedselkwaliteit. Rapport DK nr 2007/065. Ede.

Faber, P.J. \& F. Tiemens (1975). De opbrengstniveaus van populier Uitvoerig verslag Rijksinstituut voor onderzoek in de bos en landschapsbouw "De Dorschkamp" Band 13(1), Wageningen.

Govaere, L. (2019). Protocol en Handleiding Derde Bosinventarisatie Vlaams Gewest. Agentschap voor Natuur en Bos, versie 2019.02

Govaere, L. (2020) Een blik op de kenmerken van bos in Vlaanderen - eerste resultaten van twee opeenvolgende Vlaamse bosinventarisaties. Bosrevue 83a: 1-14.

Govaere, L. \& A. Leyman (2020). Nieuwe cijfers over de groei van bomen in Vlaanderen. Bosrevue 90a, $1-8$.

Govaere, L., P. Van de Kerckhove, B. Roelandt, P. Sannen \& L. Schrey (2009). Handleiding Tweede Bosinventarisatie Vlaams Gewest. Agentschap voor Natuur en Bos, Vlaanderen, werkdocument 2009.1

Gregoire, T.G. (2006). Sampling with Partial Replacement Bibliography 1942-Present. http://environment.yale.edu/gregoire/downloads/sampling/SamplingPartialReplacementBiblio.pdf

Hohenadl W. (1936). Die Bestandesmessung, Forstwiss. Zentralblatt. 58: 51-61.

IGN (2020). Le Mémento Inventaire Forestier. Édition 2020. Institut National de L'Information Géographique et forestière, $36 \mathrm{pp}$.

Jansen, J.J. (1990). De nauwkeurigheid van de volumeschatting bij de bosinventarisatie van de boswachterij Smilde. Rapport 1990-03-20, in opdracht van het Staatsbosbeheer, Regio DrentheZuid, Landbouwuniversiteit Wageningen, vakgroep Bosbouw, 30 pp.

Jansen, J.J. (1998). Collegedictaat Bosinventarisatie (LUW 06036511)

Jansen, J.J. (1999). Stamtalschatters gebaseerd op afstanden. Manuscript.

Jansen, J.J., P.A. Zuidema, J.P.G. de Klein, J. den Ouden \& G.M.J. Mohren (2019). Planning en controle bij uitkapbeheer met casestudies in Kolkbos, Oude Trekerbos en Boombos. Wageningen University, FEM Groei en Productie Rapport 2019 - 1.

Jansen, J.J. \& A. Oosterbaan (red.), (2018). Opbrengsttabellen Nederland 2018. Wageningen, Wageningen Academic Publishers, $172 \mathrm{pp}$.

Jansen, J.J., J. Sevenster \& P.G. Faber (ed.), (1996). Opbrengsttabellen voor belangrijke boomsoorten in Nederland. IBN-DLO/Landbouwuniversiteit Wageningen, IBN rapport 221/Hinkeloord reports No.17.

Jansen, J.J., A. Oosterbaan, G.M.J. Mohren \& J. den Ouden (2018a). Groei en productie van Corsicaanse den in Nederland. Wageningen University, FEM Groei en Productie Rapport 2018 - 6, 109 blz.

Jansen, J.J., A. Oosterbaan, G.M.J. Mohren \& J. den Ouden (2018b). Groei en productie van Oostenrijkse den in Nederland. Wageningen University, FEM Groei en Productie Rapport $2018-7$, 96 blz.

Kramer, H. \& J. Clement (2016). Basiskaart Natuur 2009; een landsdekkend basisbestand voor de terrestrische natuur in Nederland. Wageningen, Wettelijke Onderzoekstaken Natuur \& Milieu, WOttechnical report $72.80 \mathrm{pp}$.

Landesbetrieb Wald u. Holz (2014). Die Wälder Nordrhein-Westfalens im Blick. Ergebnisse der landesweiten Waldinventur 2014. Landesbetrieb Wald und Holz Nordrhein-Westfalen, Ministerium für Klimaschutz, Umwelt, Landwirtschaft, Natur- und Verbraucherschutz des Landes NordrheinWestfalen, $48 \mathrm{pp}$. 
Liang, X., V. Kankare, J. Hyyppä, Y. Wang, A. Kukko, H. Haggrén, X. Yu, H. Kaartinen, A. Jaakkola, F. Guan, M. Holopainen, M. Vastarant (2016). Terrestrial laser scanning in forest inventories. ISPRS Journal of Photogrammetry and Remote Sensing Volume 115, May 2016, Pages 63-77

Lin, Y. \& M. Herold (2016). Tree species classification based on explicit tree structure feature parameters derived from static terrestrial laser scanning data. Agricultural and Forest Meteorology $216,105-114$.

Matern, B. (1960). Spatial Variation. Meddelanden from Statens Skogsforsknings-Inst. 49, 1-144.

Munro, D.D. (1974). Forest growth models - a prognosis. In: Proceedings of meetings in 1973 Growth models for tree and stand simulation. IUFRO Working Party S4.01.4. Rapporter och Uppsatser, Institutionen for Skogsproduktion; 1974. (30):379 pp.

Oldenburger, J. \& H. Schoonderwoerd (2016). Chapter 31: The Netherlands. In: C. Vidal et al. (eds.), National Forest Inventories. Springer International Publishing Switzerland, 581-599

OPTAB (1989). (software pakket) . "De Dorschkamp", programmaredacteur: W.Timmer, wetenschappelijke redacteur: P.J. Faber.

Raggers, J. (2019). Handleiding Bosinventarisatie en Bosmeten; Thema Het Beheersplan. Hogeschool VHL.

Ritskes T.M. \& W.P. Daamen (1987). Doelstelling en uitvoering Vierde Bosstatistiek Nederlands Bosbouw Tijdschrift 59: 81-83.

Ruyssenaars, P.G., P.W.H.G. Coenen, P.J. Zijlema, E.J.M.M. Arets, K. Baas, R. Dröge, G. Geilenkirchen, M. 't Hoen, E. Honig, B. van Huet, E.P. van Huis, W.W.R. Koch, R. te Molder, J.A. Montfoort, T. van der Zee and M.C. van Zanten (2021). Greenhouse gas emissions in the Netherlands 1990-2019. National Inventory Report 2021. RIVM, National Institute for Public Health and Environment, Bilthoven, The Netherlands, RIVM report 2021-0007, 426 pp.

Schelhaas, M.J., A.P.P.M. Clerkx, W.P. Daamen, J.F. Oldenburger, G. Velema, P. Schnitger, H. Schoonderwoerd \& H. Kramer (2014). Zesde Nederlandse Bosinventarisatie; Methoden en basisresultaten. Wageningen, Alterra Wageningen UR (University \& Research centre), Alterrarapport 2545. $98 \mathrm{blz}$.

Schelhaas, M.J., E. Arets \& H. Kramer (2017). Het Nederlandse bos als bron van CO2. Vakblad Ntuur, Bos Landschap, pp 6-9.

Schoonderwoerd, H, (1981). De inventarisatie van landschappelijke elementen met behulp van luchtfoto's : een vooronderzoek t.b.v. de Vierde-Bosstatistiek. Scriptie Boshuishoudkunde.

Schoonderwoerd, H., J.P.G. de Klein \& J.N. van de Schee (1991). Massatabellen voor berk, beuk, es en inlandse eik (bosbomen). Maatschap Daamen, Schoonderwoerd en de Klein, Rapport nr. 23.

Schoonderwoerd H. \& J.P.G. de Klein (1994). De ontwikkeling van massatabellen voor eik, beuk, es en berk. Nederlands Bosbouw Tijdschrift 66: 109-113.

Schumacher, F.X. \& F.S. Hall (1933). Logarithmic expression of timber-tree volume. Journal of Agricultural Research, v.47, n.9, p.719-734.

Sevenster, J., J.P.G. de Klein, J.J. Jansen \& J.P. de Vries (1996). Deel 2. Gebruiksaanwijzing. In Jansen et al. (ed.), 1996

Thies, M. and H. Spiecker, 2004 Evaluation and future prospects of terrestrial laser scanning for standardized forest inventories. Int. Arch. Photogramm., Remote Sens. Spatial Inform. Sci., 36 (2004), pp. 192-197.

Valdés, A., J. Lenoir, P. De Frenne et al. (2020). High ecosystem service delivery potential of small woodlands in agricultural landscapes. Journal of Applied Ecology 57: 4-16.

Ware, K.D. \& T Cunia, 1962.Continuous Forest Inventory With Partial Replacement of Samples. Forest Science Monograph \#3: 1-40

Waterinckx, M \& Roelandt, B. (2001). De bosinventarisatie van het Vlaamse gewest. Resultaten van de eerste inventarisatie (1997-1999).

Westra, T., P. Verschelde, H. Van Calster, E. Lommelen, T. Onkelinx, P. Quataert, L. Govaere (2015). Opmaak van een analysestramien voor de gegevens van de Vlaamse Bosinventarisatie. Instituut voor Bos- en Natuuronderzoek / Agenschap Bos en Natuur, INBO.R.2015.9034827 ANB/KOBE2013/003, 123 pp.

Wouters J., Quataert P., Onkelinx T. \& Bauwens D. (2008). Ontwerp en handleiding voor de tweede regionale bosinventarisatie van het Vlaamse Gewest. Rapporten van het Instituut voor Natuur- en Bosonderzoek 2008 (INBO.R.2008.17). Instituut voor Natuur- en Bosonderzoek, Brussel. 


\section{Bijlage 1: Aandachtspunten vooronderzoek NBI-7}

Ter voorbereiding van de NBI-7 zijn in een vooronderzoek (Clerkx et al., 2017) een aantal vragen en aandachtspunten geformuleerd, die nadere aandacht vroegen bij de uitvoering. Deze worden hieronder kort geëvalueerd met betrekking tot de opvolging in NBI-7.

1. Hoe moet worden omgaan met steekproefpunten die niet als bos worden ervaren, maar wel vallen onder de voorgeschreven LULUCF-bosdefinitie?

In NBI-7 wordt de steekproef gelegd op alle bos groter dan 0,5 ha. Hiermee blijven de bossen tussen 0,1 en 0,5 hectare buiten beeld, tezamen goed voor een oppervlakte van mogelijk ruim 20.000 hectare (zie Arets et al. 2021). Dit is een substantieel deel van het totale bosoppervlak, en zal naar verwachting verder toenemen bij de voorziene uitbreiding van het bosareaal.

De huidige steekproefmethode is ingericht op aaneengesloten bossen van grotere omvang ( $>0,5$ hectare). Kleine landschapselementen die onder de definitie van bos vallen vereisen vaak een aangepaste opnamemethodiek. Dit werd in de afgelopen bosinventarisaties niet verder uitgewerkt. In Vlaanderen is afgestemd op de wettelijke definitie van bos en worden dergelijke elementen wel opgenomen in de Vlaamse Bosinventaris. Ook in de NBI4 zijn deze kleine elementen nog meegenomen in de inventarisatie (zie verder 3.2.2)

2. Welke internationale harmonisatie bosinventarisatietrajecten lopen er, en wat zijn de te verwachte vragen voor NBI-7?

Via het European National Forest Inventory Network (ENFIN, www.enfin.info) is een overzicht gemaakt van gebruikte methoden en definities van toegepaste bosinventarisaties. Voor NBI-7 lag de vraag voor in hoeverre de gebruikte protocollen afgestemd zouden kunnen worden op internationale methoden. Daar is in het vooronderzoek verder geen noodzaak toe gezien.

$\mathrm{Er}$ is tijdens de huidige evaluatie geen directe aanleiding gevonden om tot verdere harmonisatie over te gaan. De Nederlandse bosinventarisatie bleek de enige in Europa die gebruik maakt van variabele steekproefcirkels. Het wordt aanbevolen om over te gaan op het gebruik van steekproefcirkels met vaste plotstraal (zie verder 3.2.2), waardoor op dit punt feitelijk harmonisatie optreedt met andere Europese inventarisaties. Verder is het aan te bevelen te blijven deelnemen in Europese vergelijkingen en/of benchmarking acties zoals ENFIN en (in het verleden) COST.

3. Wat is bij de noodzakelijke uitbreiding van steekproefpunten de optimale verhouding tussen permanente en tijdelijke punten?

Vanaf NBI-7 zijn alle steekproefcirkels permanent gemarkeerd met een ingegraven transponder. Bij plots op terreinen waarvoor geen toestemming of toegang is verleend ontbreken deze markeren vrijwel geheel. Voor het terugvinden van de plots is dat volgens de veldopnemers in de meeste gevallen geen probleem. 
4. Wat zijn, ook juridisch gezien, de mogelijkheden van het beter vastleggen van locatiepunten met markers?

Voor zover bekend zijn er geen gronden waarop men zich hiertoe kan beroepen. Er is geen noodzaak om hier verder actie op uit te doen omdat meeste punten ook zonder transponder relatief eenvoudig kunnen worden teruggevonden

\section{Kan de methode van humusmeting worden verbeterd?}

Hoewel de metingen aan het humusprofiel aanvankelijk zijn meegenomen in de steekproef omwille van ecologische informatie, is in de NBI-7 het accent meer komen te liggen op de bepaling van koolstofopslag in de strooisellaag. De steekproef behelst nu drie submonsters, waarvan de diktes van de verschillende humushorizonten wordt gemeten. Koolstofvoorraden worden berekend via uit regressie afgeleide parameters per humustype.

In de huidige evaluatie wordt aanbevolen de humusmetingen te continueren. Verdere verbetering van de opname kan liggen in het vergroten van het aantal submonsters. Dit zou echter leiden tot een flinke vergroting van de meetinspanning. Wellicht kan in een nadere analyse worden onderzocht met welke betrouwbaarheid de huidige humuslagen worden gemeten(zie ook 3.2.1).

6. Wat is de beste methode om houtkwaliteit vast te stellen?

In NBI-7 wordt houtkwaliteit gemeten van de meest belangrijke boomsoorten. Het is niet duidelijk hoe deze informatie verwerkt moet worden, en in welke mate zij relevante informatie biedt. Ditzelfde speelt ook in de Vlaamse bosinventaris. Bij navraag is gebleken dat er weinig interesse is in deze gegevens, zodat verder methodologische uitwerking niet nodig is en wordt voorgesteld in de NBI-8 geen houtkwaliteit meer te meten (zie verder 3.2.1) .

7. Hoe kan de manier van vaststellen van bodemkwaliteit bijdragen aan het bepalen van de geschiktheid voor biomassaoogst.

Bodemkwaliteit wordt nu niet als een variabele opgenomen. Dit is onderdeel van de meer algemene vraag of de NBI-8 uitgebreid zou moeten worden met bodeminformatie, onder andere ook ten behoeve van koolstofmonitoring. Aanbevolen wordt om bodemparameters te schatten via een eigen protocol, waarbij overigens wel aangesloten kan worden bij de locaties van het NBI steekproefpuntennetwerk voor koppeling met informatie over bosstructuur en - samenstelling (zie verder 3.2.1).

De Bossenstrategie beoogt de afschaling van gebruik van biomassa voor energieopwekking. Tegelijkertijd laat onderzoek van de Vries et al. (2019) zien dat ook intensieve oogst van stamhout op sterk verzuurde arme zandbodems kan leiden tot afname van de voorraad voedingsstoffen in de bodem. Het monitoren van de bodemkwaliteit blijft daarom onverminderd van belang.

\section{Hoe kan de indeling voor vaststelling van het beheerdoel verbeterd worden?}

Het is lang niet altijd mogelijk om het beheerdoel af leiden uit de actuele vegetatie op en rondom het steekproefpunt. In de NBI-7 is de beheersvorm die in NBI- 6 werd opgenomen vervangen door verschijningsvorm, en de indeling aangepast en meer in lijn gebracht met de categorieën nodig voor internationale datavraag. Deze indeling voldoet. 
9. Wat is de nauwkeurigheidswinst in relatie tot extra kosten bij gebruik van Pi-bandjes of kruislings meten van de diameter in plaats van 1 maal meten?

$\mathrm{Bij}$ correct klemmen heeft een pi-bandje weinig meerwaarde. Bovendien verhoogt het gebruik van de elektronische boomklem de meetefficiency. $\mathrm{Er}$ is terecht vastgehouden aan gebruik van de boomklem.

10. Hoe kan de hoofdboomsoort of dominantie soort het beste worden gerapporteerd en hoe moet de methode daarop worden aangepast?

In het vooronderzoek wordt vastgehouden aan de categorisering van plots naar hoofdboomsoort omdat hiermee nog steeds uitdrukking kan worden gegeven "aan de ontwikkeling van de oppervlakte bos waarin de betreffende boomsoort aspectbepalend is". In de huidige evaluatie wordt geconstateerd dat met het kleinschaliger en gemengder worden van het bos een indeling in louter een-soortige aanduidingen van de hoofdboomsoort te beperkt is, en wordt aanbevolen bij hoofdboomsoort ook een aantal mengingscategorieën op te nemen (zie verder 3.2.1).

11. Wat is de meest geschikte methode voor het opnemen van verjonging?

De verjonging wordt nu opgenomen in vaste steekproefcirkels. Dit is adequaat. Wanneer de NBI overgaat op het gebruik van vaste steekproefcirkels met stralen die variëren naar grootteklassen van de aanwezige bomen kunnen deze verjongingscirkels daar moeiteloos in worden opgenomen.

12. Wat is de meest geschikte straalgrootte/methode bij plots met veel ingroei? Wanneer tussen twee opnames bomen op de steekproefcirkel een diameter bereiken boven de meetdrempel van $5 \mathrm{~cm}$ (ingroei) kan de meetinspanning sterk toenemen, of moet de plotstraal worden aangepast. In het vooronderzoek wordt geconcludeerd dat er geen aanleiding is het gebruik van een variabele plotstraal te heroverwegen. In de huidige evaluatie wordt echter aanbevolen wel over te gaan op gebruik van vaste plotstralen. Daarbij kan voor verschillende diameterklassen verschillende plotstralen worden gebruikt om te voorkomen dat een te grote meetinspanning moet worden geleverd bij veel ingroei (zie verder 3.2.2 en punt 2 hierboven).

13. Welke nieuwe technieken zijn in ontwikkeling en wanneer en hoe zijn die inzetbaar voor de NBI.

De bevindingen van het vooronderzoek worden op dit punt onderschreven (zie o.a. 3 . 2.4). 


\section{Bijlage 2: Steekproeftechniek}

Interne nota ten behoeve van Evaluatie NBI-7 door Hans Jansen

\section{B2.1 Inleiding}

Een belangrijke, maar nauwelijks te beantwoorden, vraag bij het opstellen van een ontwerp van een nationale bosinventarisatie betreft de vereiste nauwkeurigheid van de steekproef en de daarmee samenhangende efficiëntie van de steekproefname. In de praktijk worden dergelijke vragen niet opgeworpen en gaat men uit van bestaande methoden en gebruiken uit het verleden en probeert men binnen een vast budget de meest nauwkeurige zuivere schatters te ontwikkelen.

In de beschrijving van de NBI-7 (www.probos.nl) valt de volgende zin op: "De algemene doelstelling van de Zevende Nederlandse Bosinventarisatie is het steekproefsgewijs inventariseren van het Nederlandse bos om de staat ervan te kunnen beschrijven". Aangezien de Zevende Nederlandse Bosinventarisatie ${ }^{1}$ ten tijde van de huidige evaluatie nog niet afgerond is voor een nadere analyse van het steekproefontwerp de werkwijze uit het rapport ${ }^{2}$ van de Zesde Nederlandse Bosinventarisatie (Schelhaas et al. 2014) gebruikt. Hierbij wordt impliciet aangenomen dat de verwerking niet wezenlijk verschilt tussen NBI-6 en NBI-7. In Paragraaf B2.6 Discussie zal nader op de verschillen worden ingegaan.

\section{B2.2 Steekproefontwerp}

In NBI-7 zijn ruim 3000 steekproefpunten getrokken in ruim 340.000 ha bos Een belangrijke vraag daarbij is of met dit aantal steekproefpunten voldoende nauwkeurige informatie wordt verkregen. In Tabel 4.1 van het rapport over NBI-6 (Schelhaas et al. 2014) wordt gemeld dat er 286.852 ha opgaand bos in Nederland is met een $95 \%$ betrouwbaarheidsinterval van $\pm 3.7 \%$ op basis van 3393 steekproefpunten. Echter, voor de veel minder voorkomende categorie hakhout bedraagt deze marge $\pm 31 \%$. Halvering van het huidige aantal steekproefpunten zal voldoende nauwkeurige informatie opleveren voor de oppervlakte opgaand bos, maar voor allerlei bijzondere niches zal dan de betrouwbaarheid nog verder afnemen (lees: het betrouwbaarheidsinterval toenemen). We gaan er daarom van uit dat de keuze voor de 3393 steekproefpunten verstandig is.

In NBI-6 wordt het Nederlandse bos steekproefsgewijs bemonsterd. Leidend hierbij is de bossenkaart waarin Nederland is ingedeeld in uurhokken (oppervlakte-eenheden van $1 \mathrm{x}$ $1 \mathrm{~km}$, dus $100 \mathrm{ha}$ ). In elk van deze eenheden waarin volgens deze kaart bos ligt wordt dan een aselect steekproefpunt gekozen. Omdat de kaart wordt gemaakt door clustering

\footnotetext{
${ }^{1}$ De Zevende Nederlandse Bosinventarisatie zal hierna als NBI-7 worden aangeduid, evenzo NBI-6 voor de Zesde.

${ }^{2}$ Alle verwijzingen naar rapport, paginanummers, tabellen e.d. betreffen Schelhaas et al., 2014
} 
van een aantal pixels is het goed mogelijk dat een aselect gekozen steekproefpunt in een ander terreintype valt dan bos. Evengoed zou het mogelijk zijn om in zo'n 100 ha eenheid wat niet als bos is geclassificeerd een steekproefpunt te trekken dat in bos blijkt te liggen.

Er zijn drie aandachtspunten, waardoor er geen sprake is van een aselecte steekproeftrekking:

1. De keuze van de eenheden zelf berust op een systematisch steekproeftrekking. $\mathrm{Er}$ bestaat geen theorie hoe in zo'n geval varianties moeten worden geschat. Volgens Matern (1960) en de Vries (1986) kan het best worden uitgegaan van een aselecte steekproeftrekking, met de wetenschap dat schatters zuiver zijn en de varianties licht worden overschat. Hoewel dat niet expliciet vermeld is, is het aannemelijk dat dit principe bij NBI-6 en NBI-7 is gevolgd;

2. De keuze voor de 100 ha bosvakken leidt tot een onzuivere schatter voor het hele Nederlandse bos. Immers, we krijgen alleen een zuivere schatter voor de 100 ha bosvakken als we het aantal steekproefpunten theoretisch op oneindig stellen.

3. De vraag is tevens hoe representatief de steekproefpunten zijn. Op pagina 19 van Schelhaas et al (2014) wordt de representativiteit volkomen correct berekend op ruim 110 ha (heeft te maken met de 154 steekproefpunten die niet in bos blijken te liggen), maar aangezien de echte representativiteit slechts 100 ha bedraagt, doemt de vraag op "hoe goed is de bossenkaart?". In het rapport is dat geen vraag, maar een axioma ${ }^{3}$ "de bossenkaart geeft de exacte oppervlakte bos in Nederland". Als dit principe niet was aangehouden hadden alle punten beoordeeld moeten worden, en waren er ongetwijfeld punten gevonden waar geen bos volgens de bossenkaart is maar waar wel bos aanwezig is volgens de definitie van NBI-6. Dit had tot een betrouwbaarheidsinterval geleid waarbinnen de totale oppervlakte van de bossenkaart ligt. Aangezien het totale oppervlakte bos slecht $11 \%$ van het landsoppervlak beslaat hadden er dan ruim negen maal $(=100 / 11)$ zoveel punten beoordeeld moeten worden. Stel ruim 30000 eenheden waar er naar verwachting 154 steekproefpunten wel in bos zouden liggen. Gezien het kostenaspect hiervan achten wij dit een verantwoorde manier van werken.

Op grond van bovenstaande kan worden geconcludeerd dat het steekproefontwerp voldoet qua betrouwbaarheid en representativiteit van de resultaten.

\section{B2.2.1 Steekproefeenheden}

Het steekproefpunt is drager van een aantal eigenschappen, die enerzijds de opstand betreffen waarin het punt ligt - zoals bostype, eigendomstoestand, provincie, kiemjaarklasse - en anderzijds de boomkenmerken in een tweede steekproefeenheid in de vorm van een cirkel met een variabele straal rond het steekproefpunt. Omdat het gekozen areaal bij een opstandgrens kan liggen, wordt het deel buiten de opstand niet bemonsterd. Na wat berekeningen is daarmee de oppervlakte van de tweede steekproef bekend. De straal van de cirkel bedraagt minimaal $5 \mathrm{~m}$, als er minder dan 20 bomen binnen die $5 \mathrm{~m}$ staan wordt een grote straal gekozen, zodanig dat er minimaal 20

\footnotetext{
${ }^{3}$ De selectie van het steekproefpunt en daarmee de selectie van de opstand vindt op een ander tijdstip plaats als dat waarop de kaart is gemaakt.
} 
bomen in staan, met een maximum van $20 \mathrm{~m}$. De gedachte hierachter is enerzijds de variantie tussen jong en oud bos (dus veel en weinig bomen per ha) bij benadering gelijk te krijgen en anderzijds werkbare veldprocedure te hebben (denk bijvoorbeeld aan kapvlakten met een ijl scherm van overstaanders met weinig bomen en een natuurlijke verjonging met zeer veel bomen).

Deze tweede steekproef (ook in $\mathrm{HOSP}^{4}$ gebruikt) is een variant van een bekende afstandsmethode om dichtheden en andere opstandkenmerken te schatten de zogenaamde Zesde Boommethode. Jansen (1998) geeft in zijn collegedictaat Bosinventarisatie (LUW 06036511) een zuivere schatter voor de Zesde Boommethode, en veralgemeniseerd deze tot een $\mathrm{m}^{\mathrm{e}}$ Boommethode. Deze schatter luidt dan (voor een bewijs zie Jansen, 1999):

$$
\begin{aligned}
\hat{K} / h a= & \frac{1}{\pi \cdot n} \cdot \sum_{i=1}^{n}\left\{\frac{1}{x_{i}^{2}} \cdot \sum_{j=1}^{m-1} k_{i j}\right\} \\
& \text { met } x_{i} \text { de afstand in het } i^{\mathrm{e}} \text { plot tot de } m^{\mathrm{e}} \text { boom } \\
& \text { en } k_{i j} \text { het boomkenmerk van de } j^{\mathrm{e}} \text { boom in het } i^{\mathrm{e}} \text { plot }
\end{aligned}
$$

In NBI- 6 is formule (1) als volgt aangepast:

$$
\begin{aligned}
& \hat{K} / h a= \frac{1}{\pi \cdot n} \cdot \sum_{i=1}^{n}\left\{\frac{1}{x_{2 i}^{2}} \cdot \sum_{j=1}^{m^{*}} k_{i j}\right\} \\
& \text { met } x_{2 i}=\operatorname{Entier}\left(x_{i}\right)+1 \\
& \quad x_{i} \text { de afstand in het } i^{\mathrm{e}} \text { plot tot de } m^{\mathrm{e}} \text { boom } \\
& k_{i j} \text { het boomkenmerk van de } j^{\mathrm{e}} \text { boom in het } i^{\mathrm{e}} \text { plot } \\
& m^{*} \text { het werkelijk aantal bomen binnen een straal van } x_{2 i} \text { meter }
\end{aligned}
$$

Door deze aanpassing is Formule (2) mogelijk licht maar verwaarloosbaar onzuiver (zie ook Bijlage 3).

In deze tweede steekproefeenheid worden de bomen genummerd en de plaats met poolcoördinaten vastgelegd ${ }^{5}$. Van ieder exemplaar wordt de boomsoort bepaald, de diameter gemeten en nog een aantal aanvullende eigenschappen bepaald, zoals relatieve plaats in het kronendak, levend of staand dood of de veranderingen sinds de vorige opname (zie ook B2.2.2).

Binnen deze tweede steekproefeenheid wordt uit alle levende bomen per soort een derde aselecte steekproef getrokken van één boom (in de praktijk vaak wat meer). Van deze proefbomen wordt naast de diameter ook de hoogte gemeten. Los daarvan wordt nog een derde aselecte steekproef getrokken van enkele bomen waaraan kenmerken worden bepaald om de zaaghoutkwaliteit vast te stellen. Deze eerst genoemde proefbomen worden in boomsoortgroepen ingedeeld en met de data van deze proefbomen wordt een volumetarief (het rapport gebruikt de in de Nederlandse bosbouw meer gebruikelijke maar foutieve term massatarief) per boomsoortgroep (zie hiervoor B2.3.1).

\footnotetext{
${ }^{4}$ HOSP is een acroniem van "Houtoogststatistiek en Prognose oogstbaar hout" dat tussen eind 1988 en begin 2002 door PROBOS in vier cycli is uitgevoerd.

${ }^{5}$ Geldt voor de permante steekproefpunten, daarnaast zijn er in NBI-6 tijdelijke steekproefpunten waarbij de plaats niet wordt vastgelegd.
} 
Om het nog ingewikkelder te maken is ook nog sprake van een tweede steekproef rond het steekproefpunt, dit betreft een single sample plot (SSP) met een straal van $5 \mathrm{~m}$ waarbinnen de verjonging wordt geteld. In B2.6 wordt hierop teruggekomen.

\section{B2.2.2 Herhaalde opnames}

De opnamen van de steekproefpunten in NBI-6 betreffen heropnamen van de steekproefpunten uit Meetnet Functievervulling (MFV). Om uiteenlopende redenen zijn niet alle punten opnieuw bemonsterd. Indien alle punten wel opnieuw waren bemonsterd zou het steekproefontwerp worden geclassificeerd als "Continuous Forest Inventory" (CFI), maar dat is in de praktijk maar zelden het geval en worden er vervangende steekproefpunten getrokken. Dat is ook bij NBI-6 gebeurd, en spreekt men dan van "Sampling with Partial Replacement" (SPR). In de laatste steekproeftechniek wordt bijvoorbeeld het volume van het niet meer gekozen steekproefpunt op $t_{2}$ geschat (een soort van extrapolatie $V_{1}$ naar $V_{2}$. Omgekeerd wordt voor een nieuw plot de oude toestand $V_{1}$ geschat uit de nieuwe waarde $V_{2}$, zie Ware \& Cunia (1962), de Vries (1986) en Gregroire (2006). Uiteraard geldt dat niet voor punten die geen bos meer zijn. Bij NBI- 6 was er sprake van permanente en tijdelijke proefperken (bij de tijdelijke proefperken ontbrak de plaatsbepaling van de afzonderlijke bomen). Er waren 1343 permanente proefperken in NBI-6, en 1235 daarvan werden teruggevonden. Bij de verwerking van NBI-6 blijkt dat gekozen is voor CFI in plaats van SPR; een gemiste kans om de nauwkeurigheid bij gelijkblijvende zuiverheid te verhogen. Hierdoor is de bijgroei slecht bepaald 1235 in plaats van 2070 plots.

Enig begrip moet hier wel voor worden opgebracht, omdat bij de opname zelf er weer sprake is van "Two-phase Sampling". Er zijn dan voor wat betreft het aspect permanent/tijdelijk geen kant en klare formules voor de variantie te vinden zijn en moet er gebruik worden gemaakt van Jack-knifing of Bootstrapping. Desondanks wordt hier aangeraden gebruik te maken van SPR .

\section{B2.3 Volume}

Rekening houdend met het gewicht (de oppervlakte behorend bij het steekproefpunt) moet voor iedere afzonderlijke boom behorend tot een zekere klasse $k$ het volume per ha worden bepaald, en vervolgens opgehoogd als volgt:

$$
\begin{aligned}
V h a= & \sum_{j=1}^{n k}\left(\sum_{i=1}^{n b_{j, k}} v h a_{i, k}\right) / n k \\
& \text { met } v h a_{i k}=\frac{v_{i k}}{1000 \cdot a_{j}} \mid i \in k \text { waarbij vha in } \mathrm{m}^{3} \mathrm{ha}^{-1}, d b h \text { in } \mathrm{cm} \text { en } a_{j} \text { het oppervlak plot } j \text { in ha } \\
& \text { met } v_{i k}=f(d b h) \mid i \in k \text { waarbij } v_{i k} \text { in } \mathrm{dm}^{3} \text { en } d \text { in } \mathrm{cm} f(d b h) \text { het volumetarief } \\
& i \text { index voor } i^{\mathrm{e}} \text { boom in plotnumer } j \text { behorend tot klasse } k \\
& n b_{\mathrm{j}, \mathrm{k}} \text { totaal aantal bomen van klasse } k \text { in } j^{\mathrm{e}} \text { plot } \\
& n k \text { totaal aantal plots waar bomen van klasse } k \text { voorkomen }
\end{aligned}
$$

In B2.3.3 wordt de volumeberekening uitgelegd, maar eerst wordt in B2.3.1 het volumetarief besproken. 


\section{B2.3.1 Volumetarief}

Om tot een volumetarief te komen moet eerst het volume per boom worden bepaald. Dat was bij staande bomen in de bosbouw lang problematisch, er bestaan wel theoretische concepten:

- Staand cuberen met een dendrometer met meerdere secties;

- Pressler's richthoogte methode;

Met de komst van een elektronische hoogtemeter (Nikon Forestry 550 laser ranger) die als dendrometer kan worden ingezet behoort directe bepaling tot de mogelijkheden. Nog veelbelovender is het gebruik van TLS (terrestrial laser scanning, zie bijvoorbeeld Thies \& Spiecker, 2004; Liang et al., 2016). Dat maakt extreem nauwkeurige 3D scans van bomen, die vervolgens ook kunnen worden gecubeerd. Daarmee zou vrij snel een groot aantal bomen kunnen worden bemonsterd, afhankelijk van de resolutie kan er daarbij gekozen worden voor alleen diameter en hoogte (Figuur B2.1a), het spilhoutvolume (Figuur B2.1b), dikhoutvolume (Figuur B2.1c), volume van de totale bovengrondse houtige biomassa (Figuur B2.1d en 1e met een marginaal verschil in definitie).

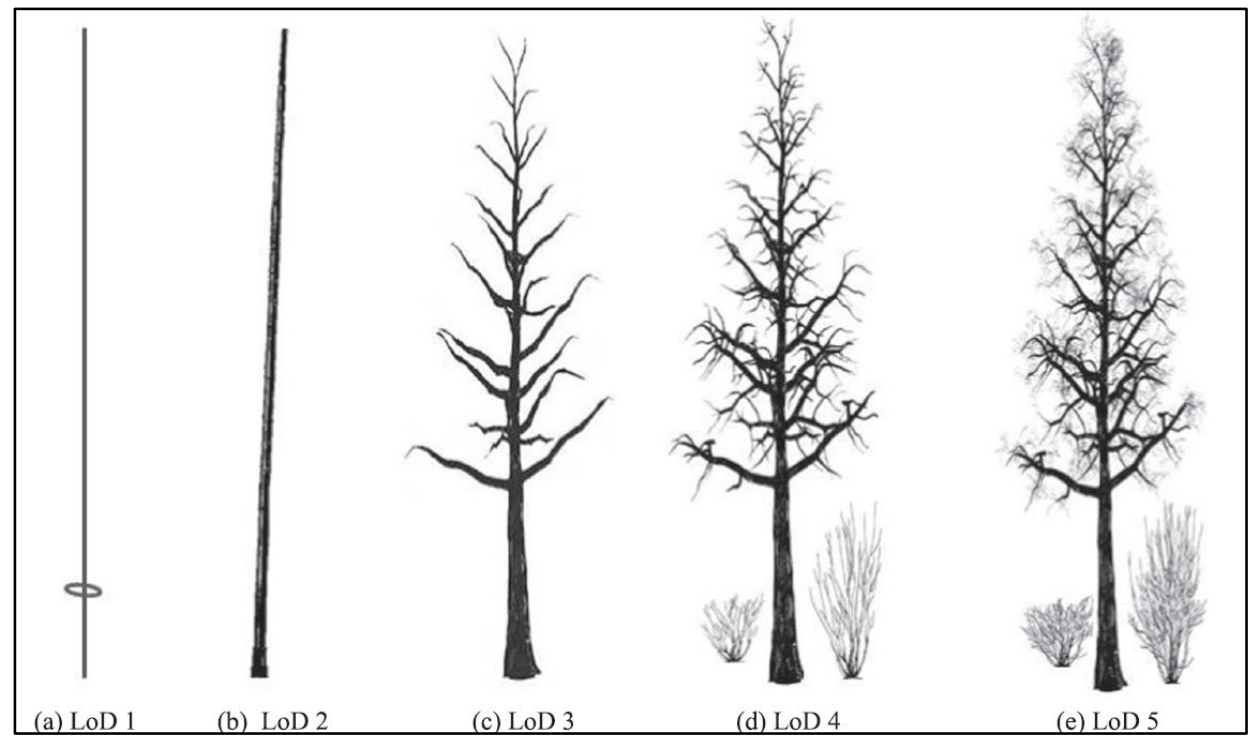

Figuur B2.1: Niveau van details in het 3D model bij TLS (naar Liang et al., 2016)

Voor staand cuberen moeten de diameters op 5 tot 10 verschillende hoogten worden gemeten en de volumes van de tussenliggende stamdelen worden berekend met de formule van Smalian. De som van de delen levert een nagenoeg zuivere schatter op van het spilhoutvolume van de boom.

Voor Pressler's richthoogte methode moet de hoogte worden bepaald waarop de diameter de helft van de dbh bedraagt en de methode levert een asymptotisch rake model-based schatter van het spilhoutvolume op.

Voor nadere details over Smalian en Pressler, zie bijvoorbeeld Jansen (1998).

In NBI-7 is gekozen de proefbomen te cuberen met behulp van een volumetabel (ook wel als massatabel aangeduid), waarbij gebruik gemaakt wordt van de formule waarmee deze tabellen zijn gemaakt. Deze tabellen zijn deels opgesteld door Dik (1984, 
1990, 1992) voor spilhoutvolume en voor populier ook werkhoutvolume. Daarnaast geven Schoonderwoerd et al. (1991) volumefuncties voor zowel spilhout- als werkhoutvolume.

Hier is dus sprake van een zogenaamd out-place element in het steekproefconcept. Dit heeft twee nadelen:

- Het is onbekend of de schatting zuiver is. Vooral bij de data van Dik is dat een probleem, omdat het merendeel van de data bestaat uit sectiemetingen verricht aan gedunde bomen op een beperkt aantal locaties uit proefperken. Deze liggen nooit dicht bij bosranden, dus randbomen zijn meestal uitgesloten bij de data;

- Negeren van de variantiecomponent uit de volumetabellen.

$\mathrm{Nu}$ het technologisch mogelijk is kan in een volgende opname tot een volledige in-place inventarisatie over worden gegaan door (een deel van) de proefbomen staand te cuberen (al of niet met TLS) en hiermee nieuwe volumetabellen te maken. Een dergelijke werkwijze zal wel leiden tot extra kosten. Als tussenoplossing kunnen nieuwe volumefuncties los van de NBI steekproefpunten worden ontwikkeld, wat waarschijnlijk efficiënter is.

De huidige volumetabel is gemaakt met het model van Schumacher-Hall (1939) $v=e^{c_{3}} \cdot d b h^{c_{1}} \cdot h^{c_{2}}$ met $d b h$ in $\mathrm{cm}, h$ in $\mathrm{m}$ en $v$ in $\mathrm{dm}^{3}$

Dik heeft in navolging van Schumacher-Hall de parameters logaritmisch geschat, zonder gebruikelijke zuiverheidscorrecties van $c_{3}$ toe te passen. Die volumetabellen zijn echter alleen voor belangrijke boomsoorten gemaakt. Voor Corsicaanse en Oostenrijkse den zijn er twee tabellen, één voor het Kustgebied en één voor het Binnenland. In het geval geen volumetabellen beschikbaar zijn voor een soort moet een specifieke volumetabel worden gekozen (zie hiervoor B2.3.2).

Cunia (1964) stelt dat voor dit soort modellen en ook voor een volumetarief er sprake is van heteroscedasticiteit (in dit geval hoe dikker de boom hoe groter de residuen). Hij gebruikt daartoe het volgende model:

$\underline{v}=f(d)+d b h^{k / 2} \cdot \sigma \cdot \underline{e}$

met $\sigma$ is de standaarddeviatie bij een homoscedastisch model

In een regressieanalyse betekent dit dat met een regressiegewicht $w$ gewerkt moet worden:

$w=d b h^{-k}$

Op grond van diverse studies beveelt Cunia aan om voor de factor $k$ de waarde 4 te gebruiken. Jansen (1990) vindt bij een case studie voor de boswachterij Smilde waarbij ook de variantiecomponent van de volumetabellen wordt meegenomen een gewicht van 3.5.

In NBI-7 wordt voor de volumetarieffunctie $f(d)$ het model van Hohenadl/Krenn (1936) gebruikt. Hohenadl stelt dat voor ieder boomkenmerk binnen een opstand een tweedegraadspolynoom volstaat, dus in dit geval:

$v_{\text {tar }}=\hat{v}_{\text {tab }}=\hat{b}_{0}+\hat{b}_{1} \cdot d b h+\hat{b}_{2} \cdot d b h^{2}$ voor alle bomen

waarbij geldt: $\underline{v}_{t a b}=b_{0}+b_{1} \cdot d b h+b_{2} \cdot d b h^{2}+\sigma \cdot \underline{e}$ voor de proefbomen 
Bij gebruik van dit model bestaat het gevaar dat een minimum of maximum gevonden wordt binnen de grenzen waarbinnen het model moet worden toegepast. Berkhout (1920) onderkende dit probleem al eerder en stelde een andere functie voor:

$v_{t a b}=b_{0} \cdot d b h^{b_{1}}$

Hierna worden enige aspecten toegelicht met berekeningen deze zijn alle gebaseerd op het rapport en database van NBI-6. Figuur B2.2 geeft voor beide modellen de gefitte curves voor alle Corsicaanse dennen. Het eerder gesignaleerde probleem blijkt hier op te treden (evenals bij drie andere boomsoortgroepen). Daarnaast bleek $R^{2}$ adj voor het powermodel met 0.979 hoger dan de 0.951 van het kwadratische model. Bij 13 andere boomsoortgroepen bleek dat eveneens het geval en in 4 gevallen was het kwadratische model beter.

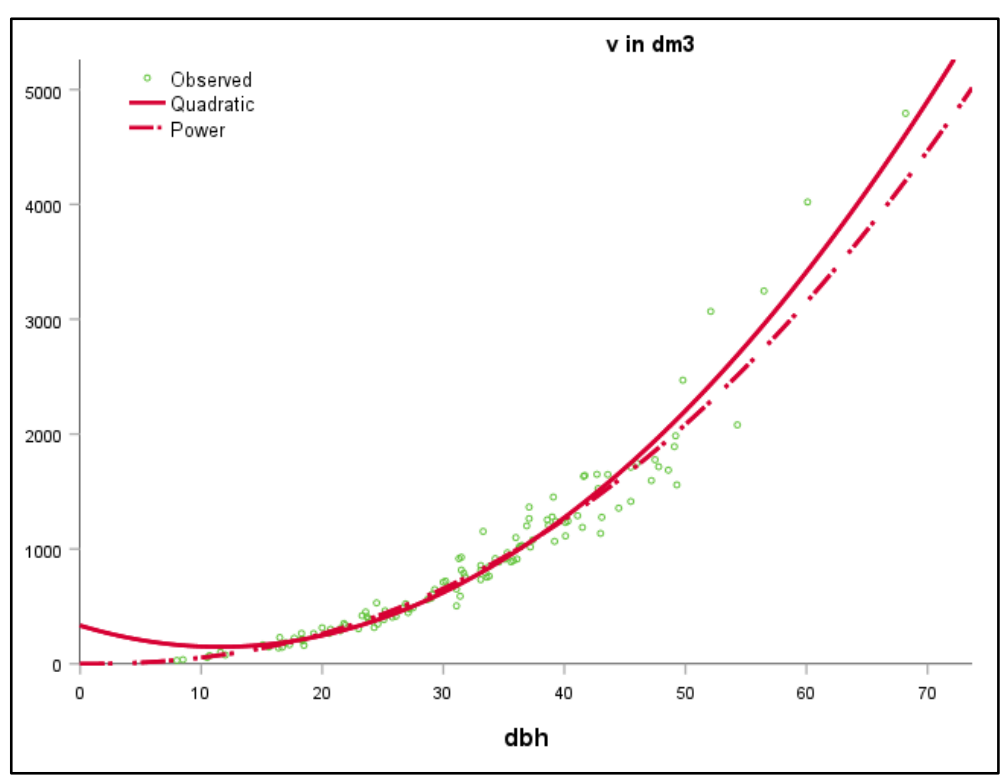

Figuur B2.2: Curvefit voor Corsicaanse den met alle proefbomen in NBI-6.

Hierna zijn de regressiegewichten geschat. Aangezien de variantie in de data van de volumetabel niet is meegenomen, zal de waarde 4 in Formule (8) meestal lager uitvallen. Voor Corsicaanse den werd 2.64 gevonden; voor de andere soorten varieerde dat van 1.47 tot 6.61. Maar men mag uiteraard niet in dezelfde studie een regressiegewicht gebruiken, dat eerst met dezelfde data is berekend. Daarom is op advies van Jansen (1990) voor 3.5 gekozen, dus $w=d b h^{-3.5}$. Met gebruikmaking van dit regressiegewicht zijn de curven nogmaals gefit in Figuur B2.3. De curven liggen nu tot een $d b h$ van $50 \mathrm{~cm}$ nagenoeg op elkaar, de $\mathrm{R}^{2}$ adj bedraagt 0.971 voor de tweedegraadspolynoom en 0.988 voor het powermodel. 


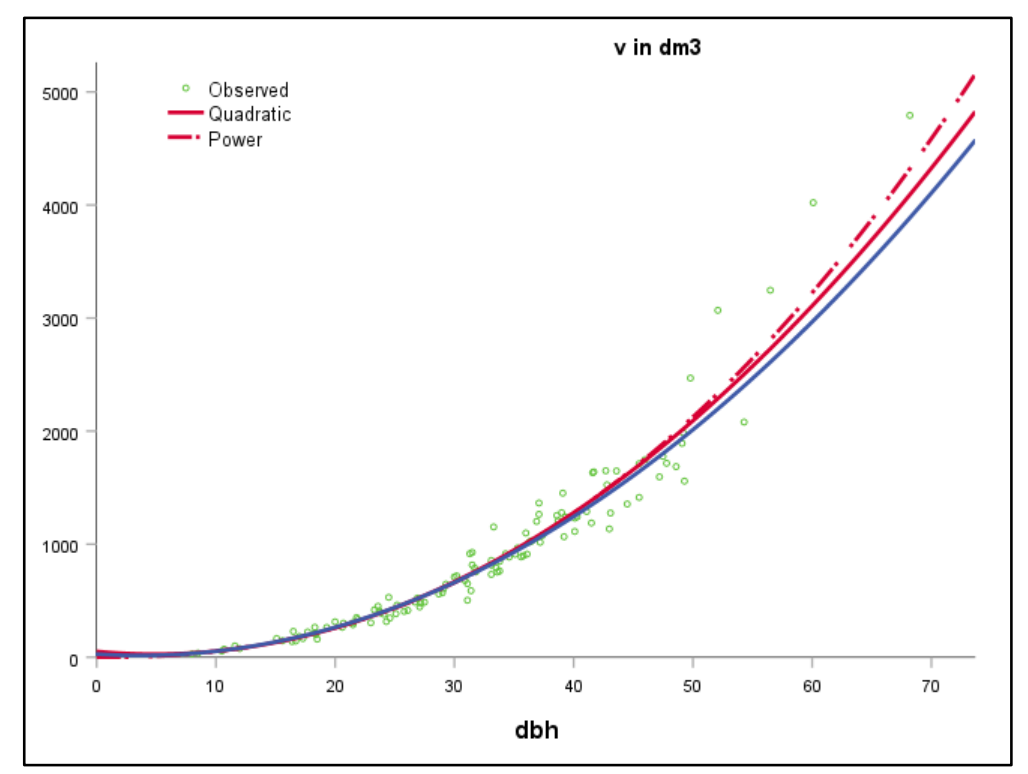

Figuur B2.3: Curvefit voor Corsicaanse den met weglating van uitbijters bij de proefbomen en met regressie gewicht, met blauwe lijn met de parameters uit het NBI-6 rapport.

In Figuur B2.3 is tevens de tweedegraadspolynoom uit het rapport getekend (blauwe vaste lijn); er is nauwelijks waarneembaar verschil met de hier berekende lijn (rood en vast). We hebben niet kunnen achterhalen hoe dit in het rapport is berekend, waarschijnlijk met een speciale selectie van de data (bijvoorbeeld geen uitbijters of met Cook's distance $<1$ ) een ander regressiegewicht of misschien met ingebouwde condities. Ons inziens dient dit soort informatie in het rapport vermeld te worden.

\section{B2.3.2 Nadere beschouwing van de in NBI gebruikte volumetabellen}

De volumetabellen zijn deels opgesteld door Dik (1984, 1990, 1992) en deels door Schoonderwoerd et al. (1991). Daarbij is het spilhoutvolume het meest gangbaar, en soms zijn ook functies voor het werkhoutvolume gegeven. Sevenster et al. (1996) geven hiervoor de volgende definities:

Onder boomvolume wordt de inhoud van houtige delen van een boom verstaan. Afhankelijk van de begrenzing van de houtige delen kan er sprake zijn van b.v. boomspilhoutvolume, boomwerkhoutvolume od boomdikhoutvolume.

Onder spilhout verstaat men dat deel van een boom, dat gevormd wordt door de stam (spil) tussen maaiveld en top, met inbegrip van de schors, maar zonder de zijtakken, ongeacht hun dikte. Bij oudere bomen, met name bij loofhout, kan er sprake zijn van een oplossende spil; in dat geval is de spil gedefinieerd als de in het verlengde van de stam meest rechtdoorgaande tak.

Onder werkhout (of stamwerkhout) wordt dat deel van het spilhout verstaan, dat zich boven stobhoogte bevindt, voor zover het dikker is dan de aftopdiameter. Daarvoor wordt ten behoeve van de volumetabellen een diameter van $7 \mathrm{~cm}$ gehanteerd, maar ook andere aftopdiameters zijn mogelijk Onder takwerkhout verstaan we het takhout dikker dan de aftopdiameter.

Het totaal van (stam)werkhout en takwerkhout wordt met de niet zo algemene benaming van "dikhout" aangeduid. In de huidige praktijk wordt zowel spilhout, werkhout als dikhout uitgedrukt in $\mathrm{m}^{3}$ incl. schors. Indien het om volumina exclusief schors gaat moet dit aan het begrip worden toegevoegd. 
Het voordeel van het gebruik van volumetabellen betreft de kostenbesparing. Men hoeft immers alleen hoogte en diameter van de proefboom te bepalen in plaats van staand te cuberen of de proefboom te vellen.

De nadelen betreffen alle de zuiverheid, onbekend is namelijk of de gebruikte volumetabellen gemiddeld in Nederland het volume zuiver schatten vanwege de volgende punten:

1. Geen zuiverheidscorrectie toegepast (bij verwerking door Dik);

2. De waarnemingen komen voornamelijk uit permanente proefperken uit het groei- en productieonderzoek en betreffen voornamelijk sectiemetingen aan dunningsbomen en vormen dus geen aselecte steekproef;

3. Rond die proefperken ligt een bufferzone, waardoor randbomen niet voorkomen;

4. Bomen met afwijkende stamvormen, zoals dubbelstammen en ooievaarsnesten zijn nooit gekozen;

5. Keuze voor een vervangende volumetabel als deze voor een soort ontbreekt.

Voor de tabellen van Schoonderwoerd et al. spelen alleen de punten 4 en 5 en daarnaast speelt hier ook het geringe aantal waarnemingen een rol (250 stuks in plaats van de meer dan 1000 per soort bij Dik).

In NBI-6 en NBI-7 is niet expliciet vermeld welke boomsoorten met welke volumetabel zijn gecubeerd, noch is vermeld of het gebruikte volume spilhout of werkhout betreft. Wel is vermeld dat parameterwaarden uit Jansen et al. (1996) komen, maar dat geeft onvoldoende duidelijkheid. Daarom is met gebruik van de dataset "Data_NBI_proefbomen" van NBI-6 onderzocht welke waarden voor de parameters uit formule (4) zijn gebruikt (zie Tabel B2.1 voor gevonden resultaten die in Tabel B2.2 zijn geordend naar volumetabel). 
Tabel B2.1. Gevonden waarden van de parameters van formule (4) per boomsoort en de daarbij behorende volumetabel.

\begin{tabular}{|c|c|c|c|c|c|}
\hline boomsoort & volumetabel & $\mathrm{n}$ & c1 & c2 & c3 \\
\hline$A B$ & $\mathrm{PO}$ & 9 & 1.78507 & 1.10325 & -3.05042 \\
\hline$A C$ & $\mathrm{AE}$ & 31 & 1.83932 & 0.97240 & -2.71877 \\
\hline$A E$ & $\mathrm{AE}$ & 358 & 1.83932 & 0.97240 & -2.71877 \\
\hline$A G$ & AG & 22 & 1.77220 & 0.96736 & -2.45224 \\
\hline AV & $\mathrm{AE}$ & 171 & 1.83932 & 0.97240 & -2.71877 \\
\hline BE & $\mathrm{BE}$ & 1088 & 1.59191 & 1.21927 & -2.79100 \\
\hline$B U$ & $\mathrm{BU}$ & 386 & 1.87602 & 1.02735 & -3.05823 \\
\hline BW & $\mathrm{AE}$ & 25 & 1.83932 & 0.97240 & -2.71877 \\
\hline$C D$ & $C D$ & 119 & 1.89192 & 0.95374 & -2.72505 \\
\hline $\mathrm{CH}$ & AG & 5 & 1.77220 & 0.96736 & -2.45224 \\
\hline DG & DG & 374 & 1.90053 & 0.80726 & -2.43151 \\
\hline DK & $\mathrm{AE}$ & 44 & 1.83932 & 0.97240 & -2.71877 \\
\hline ED & ES & 133 & 1.82300 & 1.02343 & -2.84650 \\
\hline El & EI & 1335 & 1.83069 & 1.09381 & -2.99883 \\
\hline EL & $\mathrm{JL}$ & 4 & 1.87077 & 1.00616 & -2.87480 \\
\hline ES & ES & 166 & 1.82300 & 1.02343 & -2.84650 \\
\hline ES & & 6 & \multicolumn{3}{|c|}{ geen oplossing } \\
\hline FS & FS & 196 & 1.75055 & 1.10897 & -2.75863 \\
\hline$G D$ & GD & 1239 & 1.82075 & 1.07427 & -2.88085 \\
\hline GE & $\mathrm{BE}$ & 8 & 1.59191 & 1.21927 & -2.79100 \\
\hline GW & $\mathrm{AE}$ & 1 & 1.83932 & 0.97240 & -2.71877 \\
\hline$H B$ & $\mathrm{AE}$ & 42 & 1.83932 & 0.97240 & -2.71877 \\
\hline $\mathrm{HU}$ & $\mathrm{AE}$ & 35 & 1.83932 & 0.97240 & -2.71877 \\
\hline $\mathrm{HZ}$ & $\mathrm{HZ}$ & 58 & 1.89932 & 0.97240 & -2.71877 \\
\hline IE & $\mathrm{AE}$ & 28 & 1.83932 & 0.97240 & -2.71877 \\
\hline IL & $\mathrm{AE}$ & 14 & 1.83932 & 0.97240 & -2.71877 \\
\hline$J E$ & AG & 3 & 1.77220 & 0.96736 & -2.45224 \\
\hline $\mathrm{JL}$ & $\mathrm{JL}$ & 295 & 1.87077 & 1.00616 & -2.87480 \\
\hline KM & $\mathrm{AE}$ & 1 & 1.83932 & 0.97240 & -2.71877 \\
\hline KN & ES & 6 & 1.82300 & 1.02343 & -2.84650 \\
\hline
\end{tabular}

\begin{tabular}{|llrrrr|}
\hline boomsoort & volumetabel & $\mathbf{n}$ & $\mathbf{c 1}$ & $\mathbf{c 2}$ & $\mathbf{c 3}$ \\
\hline LB & ES & 216 & 1.82300 & 1.02343 & -2.84650 \\
LG & ES & 1 & 1.82300 & 1.02343 & -2.84650 \\
LI & AE & 20 & 1.83932 & 0.97240 & -2.71877 \\
MD & BE & 59 & 1.59191 & 1.21927 & -2.79100 \\
NE & ES & 7 & 1.82300 & 1.02343 & -2.84650 \\
NO & AG & 4 & 1.77220 & 0.96736 & -2.45224 \\
OD & OD & 44 & 1.95645 & 0.88671 & -2.76750 \\
OS & FS & 1 & 1.75055 & 1.10897 & -2.75863 \\
PC & PC & 2 & 1.90611 & 1.04527 & -2.85399 \\
PK & AE & 6 & 1.83932 & 0.97240 & -2.71877 \\
PO & PO & 125 & 1.78507 & 1.10325 & -3.05042 \\
RP & PO & 14 & 1.78507 & 1.10325 & -3.05042 \\
SA & AE & 55 & 1.83932 & 0.97240 & -2.71877 \\
SD & AE & 6 & 1.83932 & 0.97240 & -2.71877 \\
SO & FS & 2 & 1.75055 & 1.10897 & -2.75863 \\
SS & FS & 22 & 1.75055 & 1.10897 & -2.75863 \\
SW & AE & 1 & 1.83932 & 0.97240 & -2.71877 \\
TH & AG & 3 & 1.77220 & 0.96736 & -2.45224 \\
TK & AE & 65 & 1.83932 & 0.97240 & -2.71877 \\
TS & AG & 17 & 1.77220 & 0.96736 & -2.45224 \\
TX & AG & 8 & 1.77220 & 0.96736 & -2.45224 \\
UL & UL & 5 & 1.83932 & 0.96736 & -2.45224 \\
VB & AE & 100 & 1.83932 & 0.97240 & -2.71877 \\
VK & AE & 24 & 1.83932 & 0.97240 & -2.71877 \\
VL & AE & 43 & 1.83932 & 0.97240 & -2.71877 \\
WD & GD & 11 & 1.82075 & 1.07427 & -2.88085 \\
WI & PO & 85 & 1.78507 & 1.10325 & -3.05042 \\
ZD & GD & 20 & 1.82075 & 1.07427 & -2.88085 \\
ZE & BE & 184 & 1.59191 & 1.21927 & -2.79100 \\
ZK & AE & 42 & 1.83932 & 0.97240 & -2.71877 \\
\hline totaal & & 7394 & & & \\
& & & & &
\end{tabular}

Tabel B2.2. Parameters per volumetabel links in NBI en rechts voor spilhout bij Jansen et al., 1996

\begin{tabular}{|c|c|c|c|c|c|c|c|c|c|c|c|}
\hline \multicolumn{7}{|c|}{ In NBI } & \multicolumn{5}{|c|}{ spilhout bij Jansen et al. 1996} \\
\hline volumetabel & $\mathbf{n}$ & c1 & c2 & c3 & volume & bron & volumetabel & c1 & c2 & c3 & bron \\
\hline $\mathrm{AE}$ & 1112 & 1.83932 & 0.97240 & -2.71877 & spilhout & OPTAB & $\mathrm{AE}$ & 1.83932 & 0.97240 & -2.71877 & OPTAB \\
\hline BE & 1339 & 1.59191 & 1.21927 & -2.79100 & 4) & onbekend & BE & 1.54291 & 1.24235 & -2.66506 & Schoonderwoerd \& de Klein, 1994 \\
\hline BU & 386 & 1.87602 & 1.02735 & -3.05823 & 4) & onbekend & BU & 1.86116 & 1.04313 & -3.05257 & Schoonderwoerd \& de Klein, 1994 \\
\hline \multirow[t]{2}{*}{$C D$} & 119 & 1.89192 & 0.95374 & -2.72505 & spilhout & OPTAB CD_B & CD_B & 1.89192 & 0.95374 & -2.72505 & OPTAB \\
\hline & & & & & & & CD_K & 1.89118 & 1.13859 & -3.22112 & OPTAB \\
\hline DG & 374 & 1.90053 & 0.80726 & -2.43151 & spilhout & OPTAB & DG & 1.90053 & 0.80726 & -2.43151 & OPTAB \\
\hline EI & 1335 & 1.83069 & 1.09381 & -2.99883 & 4) & onbekend & EI & 1.82628 & 1.11342 & -3.04885 & Schoonderwoerd \& de Klein, 1994 \\
\hline ES *) & 529 & 1.82300 & 1.02343 & -2.84650 & 4) & onbekend & ES & 1.77681 & 1.14282 & -3.07536 & Schoonderwoerd \& de Klein, 1994 \\
\hline FS & 221 & 1.75055 & 1.10897 & -2.75863 & spilhout & OPTAB & FS & 1.75055 & 1.10897 & -2.75863 & OPTAB \\
\hline GD & 1270 & 1.82075 & 1.07427 & -2.88085 & spilhout & OPTAB & GD & 1.82075 & 1.07427 & -2.88085 & OPTAB \\
\hline $\mathrm{JL}$ & 299 & 1.87077 & 1.00616 & -2.87480 & spilhout & OPTAB & $\mathrm{JL}$ & 1.87077 & 1.00616 & -2.87480 & OPTAB \\
\hline AG & 62 & 1.77220 & 0.96736 & -2.45224 & spilhout & OPTAB & AG & & ontbreekt & & \\
\hline \multirow[t]{2}{*}{ OD } & 44 & 1.95645 & 0.88671 & -2.76750 & spilhout & OPTAB OD_B & OD_B & 1.95645 & 0.88671 & -2.76750 & OPTAB \\
\hline & & & & & & & OD_K & 1.88190 & 0.91062 & -2.57403 & OPTAB \\
\hline $\mathrm{PO}$ & 233 & 1.78507 & 1.10325 & -3.05042 & 5) & onbekend & PO & 1.78865 & 1.10597 & -3.07192 & Dik, 1992 \\
\hline $\mathrm{HZ}$ 1) & 58 & 1.89932 & 0.97240 & -2.71877 & spilhout & & ZE & 1.90193 & 0.84488 & -2.55070 & Dik, 1994 \\
\hline PC 2) & 2 & 1.90611 & 1.04527 & -2.85399 & spilhout & & & & & & \\
\hline UL 3) & 5 & 1.83932 & 0.96736 & -2.45224 & spilhout & & & & & & \\
\hline \multirow{2}{*}{\multicolumn{12}{|c|}{$\begin{array}{l}\text { totaal }{ }^{*} \text { ) } \\
\text { 1) moet AE zijn met typefout in c1 }\end{array}$}} \\
\hline & & & & & & & & & & & \\
\hline \multicolumn{12}{|c|}{ 2) geen verklaring had de tabel van groveden moeten zijn } \\
\hline \multicolumn{12}{|c|}{ 3) moet $A E$ zijn met fout in $c 2$ en c3 uit $A G$} \\
\hline \multicolumn{12}{|c|}{ 4) volume > vsp dus vermoedelijk dikhout met onbekend definitie } \\
\hline \multicolumn{12}{|c|}{ 5) Volume $<$ vsp dus vermoedelijk werkhout met onkende definitie } \\
\hline ) bij ES en in 1 & otaal & tbrekend & de 6 bo & & & & & & & & \\
\hline
\end{tabular}

Waar in Tabel B2.2 als bron OPTAB is vermeld gaat dit om Dik (1984). OPTAB (1989) was een Fortran-programma van Dorschkamp/IBN, na de eerste versie werden aanpassingen van de parameters na nieuwe waarnemingen alleen in OPTAB tot 1993 bijgehouden.

$\mathrm{Na}$ verbetering van de fouten (zie voetnoten 1, 2 en 3 bij Tabel B2.2) volgt in Tabel B2.3 het gebruik per boomsoort voor een bepaalde volumetabel. 
Tabel B2.3. Gebruik van de volumetabellen per boomsoort in NBI6

\begin{tabular}{|c|c|}
\hline volumetabel & boomsoort \\
\hline$A E$ & $A C, A E, A V, B W, D K, G W, H B, H U, H Z, I E, I L, K M, L I, P K, S A, S D, S W, T K, U L, V B, V K, V L, Z K$ \\
\hline AG & $A G, A G, A G, A G, A G, A G$ \\
\hline BE & $B E, G E, M D, Z E$ \\
\hline BU & BU \\
\hline CD-B & CD \\
\hline DG & DG \\
\hline El & El \\
\hline ES & $E D, E S, K N, L B, L G, N E$ \\
\hline FS & FS, OS, SO, SS \\
\hline GD & $G D, P C, W D, Z D$ \\
\hline$J \mathrm{~L}$ & EL, JL \\
\hline OD-B & OD \\
\hline $\mathrm{PO}$ & $A B, P O, R P, W I$ \\
\hline
\end{tabular}

Er kan uit het bovenstaande het volgende worden afgeleid:

1. Voor Corsicaanse en Oostenrijkse den zijn er twee tabellen, één voor het Kustgebied en één voor het Binnenland. Alleen die voor het Binnenland zijn in NBI-6 gebruikt. Dit berust vermoedelijk op een misverstand omdat bij de nieuwe opbrengsttabellen (Jansen en Oosterbaan, 2018) dit verschil niet wordt gemaakt voor het opstandsvolume, maar in de onderliggende studies (Jansen et al., 2018a en Jansen et al., 2018b) blijkt dat verschil wel gemaakt te worden voor de boomvolumes;

2. Er is sprake van spilhouthoutvolume, maar mogelijk ook van dikhout- en werkhoutvolume;

3. De volumetabel voor de zwarte els wordt niet gebruikt.

De keuze voor het toewijzen van een volumetabel aan soorten met geen eigen tabel zou beter onderbouwd en toegelicht kunnen worden. Behoudens bovengenoemde punten met betrekking tot zwarte den en zwarte els wordt de huidige indeling hier niet expliciet ter discussie gesteld.

\section{B2.3.3 Volumeberekening}

In het rapport worden standaarddeviaties en betrouwbaarheidsintervallen alleen gepresenteerd bij tabellen met oppervlakten. Het ware wenselijk dit ook voor tabellen met volumes te doen. Jansen (1990) geeft aan hoe dit moet, voor een statistisch vergelijkbare situatie. Voor een zekere te onderzoeken klasse of deelpopulatie $k$ behorend bij steekproefpunt $j$ (bijvoorbeeld Corsicaanse den) geldt :

$v_{k j}=\sum_{i=1}^{n_{j}} \hat{v}_{k i}$

met $k$ de klasse, $i$ index voor volgnummer binnen plot $j$

$\hat{v}_{k i}=\hat{b}_{0 k}+\hat{b}_{1 k} \cdot d b h_{i}+\hat{b}_{2 k} \cdot d b h_{i}^{2}$ voor de indivuduele bomen binnen plot $j$ in klasse $k$

$n_{j}$ het aantal bomen behorend tot klasse $k$ in het $j$ plot

Voor het totale volume voor klasse $\mathrm{k}$ geldt dan: 
$V_{k}=r f \cdot \sum_{j=1}^{n} \hat{v}_{k j} /$ area $_{j}$

met $k$ de klasse, $j$ het plotnummer

area $_{j}$ de oppervlakte van het $j$ plot

$n$ totaal aantal plots, $r f$ representatie factor

$v_{k}$ totale volume voor klasse $k$

Om schatters voor de variantie te ontwikkelen is het handiger om de formules te herschrijven in matrixnotatie. Met weglating van alle indices en verkorte notatie $d$ voor $d b h$ geldt voor het volume $v$ van de $i$ boom van uit klasse $k$ in het $j$ plot

$$
\underline{v}=p^{\prime} \underline{b} \text { met } p \text { de vector }\left[\begin{array}{l}
1 \\
d \\
d^{2}
\end{array}\right] \text { en } \underline{b} \text { de vector }\left[\begin{array}{l}
\underline{b}_{0} \\
\underline{b}_{1} \\
\underline{b}_{2}
\end{array}\right]
$$

Om nu naar de som te gaan van het volume van alle bomen, zoal in Formule (9), wordt de 3 -dimensionale vector verlengt tot een $3 n_{j}$-dimensionale vector, dus met $p$ als rijvector:

$$
\underline{v}=p^{\prime} \underline{b}
$$$$
\text { met } p^{\prime}=\left[\begin{array}{llllllllll}
1 & d_{1} & d_{1}^{2} & 1 & d_{2} & \cdots & \cdots & \cdots & d_{n j} & d_{n j}^{2}
\end{array}\right]
$$

$\underline{b}$ als in Formule (8) en $v$ nu de som de volumes per boom

Voor de variantie van het volume binnen het areaal van het steekproefpunt geldt:

$$
\begin{aligned}
& \operatorname{var} \underline{v}=p^{\prime} \operatorname{COV}_{\mathrm{b}} p \\
& \quad \text { met } p^{\prime} \text { als in Formule (9) en } \operatorname{COV}_{\mathrm{b}} \text { de Covariantie-matrix van } \underline{b}
\end{aligned}
$$

Voor ophoging naar het totale volume over alle steekproefpunten geldt naar Cunia (1985):

$$
\begin{aligned}
\underline{V}_{\text {tot }}= & \underline{p^{\prime}} \underline{b} \cdot r f \\
& \text { met } p \text { gecorrigeerd voor volume in } \mathrm{m}^{3} \mathrm{ha}^{-1} \\
& p^{\prime}=\left[\begin{array}{llllllllll}
\frac{1}{a} & \frac{d_{1}}{a} & \frac{d_{1}^{2}}{a} & \frac{1}{a} & \frac{d_{2}}{a} & \ldots & \ldots & \ldots & \frac{d_{n j}}{a} & \frac{d_{n j}^{2}}{a}
\end{array}\right]
\end{aligned}
$$

$p$ een kolomvector en $p^{\prime}$ de daaruit gedraaide rijvector zo ook voor $b$ en $b^{\prime}$

en $a$ de oppervlakte behorend bij het $j$ e steekproefpunt, $r f$ representatie factor

$\operatorname{var} \underline{V}_{\text {tot }}=\left(b^{\prime} \operatorname{COV}_{p} b+p^{\prime} \operatorname{Cov}_{\mathrm{b}} p\right) \cdot r f^{2}$

In Formule (14) is overgestapt van volume in $\mathrm{dm}^{3}$ naar $\mathrm{m}^{3}$.

Bij berekening voor een bepaalde klasse $k$ worden de waarden van $p$ indien de betreffende klasse niet voorkomt alle 0 . Er zijn twee variantiecomponenten.

Variantiecomponent1 $\left(b^{\prime} \operatorname{cov}_{p} b\right)$ betreft de steekproefvariantie en variantiecomponent2 $\left(p^{\prime} \operatorname{Cov}_{\mathrm{b}} p\right)$ het volumetarief. 
Met Formule (14) kunnen nu beide componenten berekend worden. Daar zijn wat beperkingen aan:

1. Aangezien de gepresenteerde parameters op Pagina 89 van het rapport niet konden worden gereconstrueerd, moesten deze opnieuw worden berekend op de wijze zoals hiervoor voor de Corsicaanse den is beschreven. Het beste model van Berkhout kon daarbij niet worden aangehouden, omdat de variantie in dat geval alleen met Jack-knifing kan worden berekend;

2. Het aantal bomen op Pagina 89 (7264) correspondeert niet met het aantal bomen in de database (7394). De reden hiervoor bleek dat de proefbomen een extra gewicht kregen bij de berekening. Aangezien dit niets te maken heeft met het nut en gebruik van een volumetarief is dit onjuist en wordt overigens in het rapport ook niet uitgelegd. Het grootste verschil betrof overigens het tarief "Inlandse eik mid" met 550 "gewogen bomen" in het rapport en 602 "werkelijke bomen " in de database;

3. Bij de soortindeling in Tabel 10.2 is weer andere keus gemaakt dan voor de boomsoortgroepen voor de tarieven. Ook hier zijn er verschillen met de gegevens uit de database. Soms klein, zoals de toevoeging van de grauwe els aan de klasse "Zwarte els"; logisch, maar in strijd met de definiëring in Bijlage 4.

4. Daarnaast is er nog wat onopgehelderd gebruik van de volumetabellen, zie B2.3.2

Rekening houdend met deze beperkingen moet het resultaat in Tabel B2.4 niet in absolute zijn geïnterpreteerd worden. Maar het geeft wel een goed beeld van de nauwkeurigheid van de volumeschatting.

Jansen (1990) vond voor Smilde dat $90.1 \%$ van de variantie door de $1^{\mathrm{e}}$ component werd verklaard en de rest door de $2^{\mathrm{e}}+3^{\mathrm{e}}$ component, waarbij die $3^{\mathrm{e}}$ variantiecomponent de variantie uit de volumetabel betrof (hij berekende hem op $34,32 \%$ van variantiecomponent 2 ). De door hem gevolgde methode kan niet opnieuw berekend worden voor NBI- 6 in verband met beperking 4, daarom is hier ook variantiecomponent 3 geschat als 34,32\% van variantiecomponent 2 .

Tabel B2.4. Geschatte totale volume per klasse in $1000 \mathrm{~m}^{3}$.

\begin{tabular}{|c|c|c|c|c|c|c|c|c|c|c|c|c|}
\hline \multirow[b]{2}{*}{ klasse } & \multirow[b]{2}{*}{$\mathrm{n}$} & \multirow{2}{*}{$\begin{array}{c}\text { Berkhout } \\
\text { Vtot }\end{array}$} & \multicolumn{5}{|c|}{ Hohenadl model } & \multicolumn{2}{|c|}{$2 \sigma$ btbhi } & \multirow{2}{*}{$\begin{array}{c}\text { Form pag } 89 \\
v \text { tot }\end{array}$} & \multirow[b]{2}{*}{ Uit tabel } & \multirow[b]{2}{*}{ verschil } \\
\hline & & & Vtot & $\begin{array}{c}\text { varcom } \\
1\end{array}$ & $\begin{array}{c}\text { varcom } \\
2\end{array}$ & $\begin{array}{c}\text { varcon } \\
3\end{array}$ & sdv_vtot & $\begin{array}{c}\text { onder- } \\
\text { grens }\end{array}$ & $\begin{array}{c}\text { boven- } \\
\text { grens }\end{array}$ & & & \\
\hline Amerikaanse eik & 490 & 3324 & 3365 & $87.7 \%$ & $9.1 \%$ & $3.1 \%$ & 34.6 & 3296 & 3434 & 3229 & 3229 & 136 \\
\hline Berk & 1512 & 4744 & 4792 & $97.4 \%$ & $2.0 \%$ & $0.7 \%$ & 33.4 & 4725 & 4859 & 4474 & 4470 & 322 \\
\hline Beuk & 522 & 5550 & 5530 & $86.0 \%$ & $10.4 \%$ & $3.6 \%$ & 53.8 & 5423 & 5638 & 5349 & 5349 & 181 \\
\hline Es & 201 & 2962 & 2964 & $84.7 \%$ & $11.4 \%$ & $3.9 \%$ & 46.7 & 2871 & 3058 & 2734 & 2734 & 230 \\
\hline Esdoorn & 260 & 1324 & 1276 & $77.6 \%$ & $16.7 \%$ & $5.7 \%$ & 20.6 & 1235 & 1317 & 1136 & 809 & 467 \\
\hline Inlandse eik & 1598 & 17726 & 17718 & $90.7 \%$ & $6.9 \%$ & $2.4 \%$ & 104.5 & 17509 & 17927 & 15988 & 15991 & 1727 \\
\hline Populier & 132 & 2524 & 2626 & $80.4 \%$ & $14.6 \%$ & $5.0 \%$ & 43.1 & 2540 & 2713 & 2416 & 2416 & 210 \\
\hline Wilg & 100 & 1311 & 1282 & $57.9 \%$ & $31.3 \%$ & $10.7 \%$ & 26.8 & 1228 & 1336 & 1279 & 1279 & 3 \\
\hline Zwarte els & 252 & 1679 & 1702 & $89.3 \%$ & $7.9 \%$ & $2.7 \%$ & 32.6 & 1637 & 1767 & 1656 & 1656 & 46 \\
\hline Inheems loo fhout & 775 & 1362 & 1300 & $54.4 \%$ & $34.0 \%$ & $11.7 \%$ & 16.5 & 1267 & 1333 & 1333 & 1773 & -473 \\
\hline Uitheems loofhout & 144 & 803 & 785 & $69.0 \%$ & $23.1 \%$ & $7.9 \%$ & 18.7 & 748 & 823 & 829 & 872 & -87 \\
\hline Struiken & 1067 & 745 & 765 & $96.6 \%$ & $2.5 \%$ & $0.9 \%$ & 11.3 & 742 & 787 & 842 & 748 & 17 \\
\hline Totaal loofhout & & 44054 & 44106 & $86.8 \%$ & $9.8 \%$ & $3.4 \%$ & 152.1 & 43802 & 44410 & 41265 & 41326 & 2780 \\
\hline Corsicaanse den & 128 & 2910 & 2915 & $80.8 \%$ & $14.3 \%$ & $4.9 \%$ & 44.7 & 2825 & 3004 & 2846 & 2846 & 69 \\
\hline Douglas & 484 & 8163 & 8253 & $40.8 \%$ & $44.0 \%$ & $15.1 \%$ & 79.2 & 8094 & 8411 & 6691 & 6691 & 1562 \\
\hline Fijnspar & 247 & 3688 & 3623 & $68.5 \%$ & $23.5 \%$ & $8.1 \%$ & 42.5 & 3538 & 3707 & 3505 & 3505 & 118 \\
\hline Grove den & 1292 & 21819 & 21969 & $98.0 \%$ & $1.5 \%$ & $0.5 \%$ & 110.7 & 21748 & 22191 & 20183 & 20184 & 1785 \\
\hline Lariks & 349 & 4409 & 4291 & $67.2 \%$ & $24.4 \%$ & $8.4 \%$ & 42.1 & 4207 & 4375 & 3852 & 3852 & 439 \\
\hline Oostenrijkse den & 48 & 1163 & 1172 & $42.9 \%$ & $42.5 \%$ & $14.6 \%$ & 34.8 & 1103 & 1242 & 1042 & 1042 & 131 \\
\hline Overig naa Idhout & 168 & 1391 & 1423 & $67.0 \%$ & $24.6 \%$ & $8.4 \%$ & 39.4 & 1344 & 1502 & 1481 & 1481 & -58 \\
\hline Totaal naa Idhout & & 43542 & 43645 & $75.0 \%$ & $18.6 \%$ & $6.4 \%$ & 161.8 & 43321 & 43969 & 39601 & 39539 & 4106 \\
\hline Totaal & & 86582 & 87751 & $80.6 \%$ & $14.5 \%$ & $5.0 \%$ & 222.1 & 87307 & 88195 & 80866 & 80866 & 6885 \\
\hline Plotvo lume als SRS & & & 108759 & & & & 29.5 & 108700 & 108818 & & & \\
\hline
\end{tabular}


Voor bijvoorbeeld Corsicaanse den vinden we $V_{\text {tot }}=2915 \mathrm{~K} \mathrm{~m}^{3}$ in een $2 \sigma$ betrouwbaarheidsinterval $\{2825,3004\}$. Als we de variantie zouden bereken over de realisaties per steekproefpunt vinden we een smaller betrouwbaarheidsinterval $\{2890,2912\}$ omdat de variantiecomponenten 2 en 3 genegeerd worden. In de tabel is dit in de onderste regel alleen voor het totaal gegeven.

Verschil met het rapport: In de laatste kolom is het verschil weergegeven van het nu berekende Vtot met het Hohenadl model en het volume uit Tabel 10.2. De gebruikte volumetarieven lijken alleen bij Inlandse eik een probleem en dat heeft hoogstwaarschijnlijk met de eerder genoemde beperking 2 te maken. Andere grote verschillen met beperking 3 .

Voor verbetering van de nauwkeurigheid van het volume komt alleen variantiecomponent 1 in aanmerking. Dit kan alleen bereikt worden door het aantal steekproefpunten te verhogen en of de nauwkeurigheid van de diametermeting te verhogen. Gezien de al bereikte nauwkeurigheid is dit niet zinvol. Dat wordt uiteraard heel anders als we veel fijnere klassen definiëren, bijvoorbeeld "Grove den met een $\mathrm{dbh}>60 \mathrm{~cm}$ in Gelderland".

In het algemeen valt over de nauwkeurigheid van diametermeting te zeggen dat de veldinstructie zeer goed is. Er wordt éénmaal geklemd omdat (zoals uit tientallen studies) is gebleken dat de variantie van de meting binnen een boom miniem is ten opzichte van de variantie tussen bomen.

In de berekening van de oppervlakte van het doorsneevlak van de boom op borsthoogte (het zogenaamde boomgrondvlak $g$ ) wordt dat doorsneevlak gemodelleerd als een cirkel. dat is een versimpeling van de echte vorm, die vaker min of meer ellipsvormig is. Gaat het om individuele bomen dan is het beter de boom overkruis te meten, maar aangezien het doel de populatie van bomen betreft, en het eerder gestelde over de interne en externe variantie van de metingen, volstaat een enkele meting. Maar die moet bij herhaalde metingen altijd op dezelfde wijze plaatsvinden. Vandaar het voorschrift om de liniaal van de boomklem naar het plotcentrum te richten. Er is echter een tweede reden om dat te doen want in sommige opstanden is soms sprake van drukof trekhout in een bepaalde richting, de gevolgde procedure vormkomt hiermee systematische onder- of overschatting. De meting wordt op borsthoogte $(1.30 \mathrm{~m})$ uitgevoerd, waarmee de vraag oprijst: "waar is de grond?". Ook dit is in het protocol goed omschreven. In de loop der tijd is dit echter geen stabiele factor, en daarom wordt in permanente proefperken de borsthoogte op bomen vaak gemarkeerd. Dit is een optie die om statistische reden niet wenselijk is. Blijft de restpost in de variantie de individueel gemaakte fout bij de meting. Met protocol en controle opnamen is hierin in voldoende mate voorzien en worden dit soort fouten geminimaliseerd.

Variantiecomponent 3 is berekenbaar maar verdwijnt indien voor TLS wordt gekozen. Echter, naar verwachting zal dan de nieuwe variantiecomponent 2 ongeveer gelijk zijn aan de huidige som van de variantiecomponenten 2 en 3 . Desondanks heeft de voorgestelde terrestrial laser scanning echter wel degelijk zin om dat daarmee een zuivere schatter wordt gevonden, en ook de bovengrondse biomassa geschat kan worden.

Het enige wat dan nog overblijft om te onderzoeken is het aantal proefbomen per plot. Er wordt nu van iedere tarief-boomsoortgroep de eerste voorkomende boom als proefboom geselecteerd. Bij het maken van een volumetarief wordt naast het regressiegewicht nog een extra gewicht toegevoegd, de keuze van dit extra gewicht is niet goed onderbouwd. 
Een vraag is of het zinvol is om meer dan één proefboom per plot te selecteren. Er zijn nu 7394 proefbomen geselecteerd; indien we alleen de eerste boom selecteren dan gaat het om 3094 bomen. In Tabel B2.5 is te zien dat het gevonden volume behalve bij uitheems loofhout in Tabel B2.4 binnen het betrouwbaarheidsinterval van Tabel B2.5 valt en daarom is het beperken van het aantal proefbomen tot één per plot een optie. Om nieuwe volumetabellen te maken moet dan minstens de helft ervan gecubeerd worden.

Tabel B2.5: Geschatte totale volume per klasse in $1000 \mathrm{~m}^{3}$ met keuze van alleen de eerste proefboom per plot.

\begin{tabular}{|c|c|c|c|c|c|c|c|c|c|c|}
\hline \multirow[b]{2}{*}{ klasse } & \multirow[b]{2}{*}{$\mathrm{n}$} & \multirow[b]{2}{*}{ V_tot } & \multicolumn{3}{|c|}{ Variantiecomponenten in \% } & \multirow[b]{2}{*}{ Var_Vtot } & \multirow[b]{2}{*}{ sdv_Vtot } & \multicolumn{2}{|c|}{$2 \sigma$ btbhi } & \multirow{2}{*}{$\begin{array}{c}V_{-} \text {tot } \\
\text { uit tabel } 3\end{array}$} \\
\hline & & & 1 & 2 & 3 & & & ondergrens & bovengrens & \\
\hline Amerikaanse eik & 490 & 3385 & $95.6 \%$ & $3.3 \%$ & $1.1 \%$ & 3328 & 58 & 3269 & 3500 & 3365 \\
\hline Berk & 1512 & 4780 & $99.5 \%$ & $0.4 \%$ & $0.1 \%$ & 5379 & 73 & 4634 & 4927 & 4792 \\
\hline Beuk & 522 & 5638 & $93.7 \%$ & $4.7 \%$ & $1.6 \%$ & 6606 & 81 & 5476 & 5801 & 5530 \\
\hline Es & 201 & 2971 & $92.5 \%$ & $5.6 \%$ & $1.9 \%$ & 4360 & 66 & 2839 & 3103 & 2964 \\
\hline Esdoorn & 260 & 1253 & $90.2 \%$ & $7.3 \%$ & $2.5 \%$ & 936 & 31 & 1192 & 1315 & 1276 \\
\hline Inlandse eik & 1598 & 17691 & $97.0 \%$ & $2.2 \%$ & $0.8 \%$ & 32994 & 312 & 17067 & 18315 & 17718 \\
\hline Populier & 132 & 2623 & $86.7 \%$ & $9.9 \%$ & $3.4 \%$ & 2719 & 52 & 2519 & 2728 & 2626 \\
\hline Wilg & 100 & 1287 & $65.9 \%$ & $25.4 \%$ & $8.7 \%$ & 883 & 30 & 1227 & 1346 & 1282 \\
\hline Zwarte els & 252 & 1713 & $95.6 \%$ & $3.3 \%$ & $1.1 \%$ & 2651 & 51 & 1610 & 1816 & 1702 \\
\hline Inheems loofhout & 775 & 1344 & $83.9 \%$ & $12.0 \%$ & $4.1 \%$ & 780 & 38 & 1268 & 1419 & 1300 \\
\hline Uitheems loofhout & 144 & 846 & $86.1 \%$ & $10.3 \%$ & $3.5 \%$ & 889 & 30 & 787 & 906 & 785 \\
\hline Struiken & 1067 & 746 & $98.8 \%$ & $0.9 \%$ & $0.3 \%$ & 322 & 18 & 710 & 782 & 765 \\
\hline Totaal loofhout & 7053 & 44279 & $95.1 \%$ & $3.6 \%$ & $1.3 \%$ & 61847 & 249 & 43781 & 44776 & 44106 \\
\hline Corsicaanse den & 128 & 2869 & $86.9 \%$ & $9.8 \%$ & $3.4 \%$ & 2829 & 53 & 2762 & 2975 & 2915 \\
\hline Douglas & 484 & 8352 & $53.4 \%$ & $34.7 \%$ & $11.9 \%$ & 8060 & 126 & 8099 & 8605 & 8253 \\
\hline Fijnspar & 247 & 3643 & $78.3 \%$ & $16.1 \%$ & $5.5 \%$ & 2654 & 73 & 3498 & 3789 & 3623 \\
\hline Grove den & 1292 & 21771 & $98.4 \%$ & $1.2 \%$ & $0.4 \%$ & 15697 & 125 & 21521 & 22022 & 21969 \\
\hline Lariks & 349 & 4328 & $79.5 \%$ & $15.3 \%$ & $5.2 \%$ & 2854 & 73 & 4181 & 4475 & 4291 \\
\hline Oostenrijkse den & 48 & 1162 & $63.8 \%$ & $26.9 \%$ & $9.2 \%$ & 1908 & 44 & 1075 & 1250 & 1172 \\
\hline Overig naaldhout & 168 & 1409 & $82.9 \%$ & $12.7 \%$ & $4.4 \%$ & 1986 & 57 & 1295 & 1524 & 1423 \\
\hline Totaal naaldhout & 2874 & 45866 & $77.2 \%$ & $17.0 \%$ & $5.8 \%$ & 102476 & 320 & 45225 & 46506 & 43645 \\
\hline Totaal & 9927 & 90144 & $89.4 \%$ & $7.9 \%$ & $2.7 \%$ & 164323 & 405 & 89334 & 90955 & 87751 \\
\hline
\end{tabular}

\section{B2.4 Mutaties}

De verandering die geconstateerd worden tussen twee opeenvolgende opnamen moeten zoveel mogelijk op naam gebracht worden in termen van toe- en afname. Een deel daarvan betreft statistische mutaties. Op het hoogste niveau gaat dit normaliter om vormen van bebossing en ontbossing en het passeren van administratieve grenzen (denk daarbij bijvoorbeeld aan open natuurterreinen met opslag waar door groei de kronenbedekking boven de $20 \%$ komt en door beheer daar weer onder wordt gebracht). Bij statistische mutaties kan het bijvoorbeeld gaan wanneer in de toekomst bosjes met een oppervlakte $<0.5$ ha in de NBI worden betrokken.

Maar ook simpele veranderingen in de opnametechniek kunnen tot een statistische mutatie leiden. Stel dat bij NBI-8 besloten wordt de diameter anders te meten, bijvoorbeeld met TLS of een pi-bandje, dan zou dat kunnen leiden tot een andere bepaling van het boomvolume. Bij de vergelijking met NBI-7 hebben we dan te maken met een bijgroei die niet geheel het gevolg is van natuurlijke processen. Daarom is het verstandig in zo'n geval in een kleine substeekproef zowel de oude als de nieuwe meetmethode toe te passen om onderscheid te kunnen maken tussen echte bijgroei en statistische bijgroei als gevolg van het meetproces.

Op plotniveau hebben we te maken met kap, sterfte, ingroei, bijgroei en on-growth / out-growth (verandering door wijziging van de plotgrootte) en het verdwijnen van dood 
hout. Met de huidige opname-methoden worden deze verandering alle vastgesteld (behalve die van de on-growth / out-growth, maar die wordt indirect door de andere mutaties bepaald). Deze wijzigingen in het bomenbestand per plot kunnen leiden tot wijzigingen in de bossamenstelling (zoals menging en ongelijkjarigheid). In de tekst van het rapport wordt hier aandacht aan besteed, maar dit wordt verder niet cijfermatig onderbouwd. In de volgende paragraaf wordt nader ingegaan op de bijgroei.

\section{B2.5 Bijgroei}

Onder bijgroei wordt hier de volumebijgroei bedoeld. Op pagina 19 wordt over de berekening van deze bijgroei het volgende vermeld:

\section{Schatting bijgroei}

De bomen op de permanente steekproefcirkels die zowel in het MFV als in de NBI-6 zijn opgenomen, en in beide gevallen leefden, zijn gebruikt om bijgroeifuncties te schatten. Deze functies geven een schatting van de grondvlakbijgroei van individuele bomen, op basis van een aantal kenmerken van de boom en het omringende bos. De bijgroeifuncties zijn beschreven in Bijlage 7 in Schelhaas et al (2014). Deze functies zijn vervolgens gebruikt om een schatting te maken van de grondvlakbijgroei van de individuele bomen in zowel MFV als NBI6. Uit de grondvlakbijgroei wordt de jaarlijkse diametergroei bepaald, en in combinatie met de massatarieven wordt de jaarlijkse volume bijgroei afgeleid. Uit de individuele bijgroei is vervolgens voor elk steekproefpunt de bijgroei per ha uitgerekend. Dit geeft zowel een schatting van de bijgroei ten tijde van het MFV, als een schatting van de huidige lopende bijgroei.

In B2.2. is op basis van deze tekst al geconcludeerd dat we te maken hebben met een CFI verwerking van een SPR steekproefontwerp.

In Bijlage 7 (in Schelhaas et al., 2014) vinden we de volgende formule:

$$
\begin{aligned}
i_{g}=a_{0} & +a_{1} \cdot \frac{g^{p_{1}}}{G^{p_{2}}}+a_{2} \cdot\left(\frac{g}{t}\right)^{p_{3}} \text { met: } \\
i_{g} & =\text { jaarlijkse grondvlakbijgroei voor individuele boom }\left(\mathrm{cm}^{2} \mathrm{jr}^{-1}\right) \\
g & =\text { grondvlak individuele boom }\left(\mathrm{cm}^{2}\right) \\
G & =\text { grondvlak van het bos rond de boom }\left(\mathrm{m}^{2} \mathrm{ha}^{-1}\right) \text {, gedeeld door } 100 \\
t & =\text { leeftijd van de boom }(\mathrm{jr})
\end{aligned}
$$

Deze formule werd ontwikkeld door Daamen en Schoonderwoerd (1990) op basis van werk van Munro (1974) bij de analyse van de HOSP data, en was daar veel efficiënter omdat die bijgroei gerelateerd kon worden aan Kraftse boomklassen die destijds in HOSP gebruikt werden, en werd gedifferentieerd naar allerlei bijzondere omstandigheden zoals bovenstaanders of bijzondere terreintypen. Met de vergelijkbare codering "Sociale positie in kronendak" in NBI-7 is dat opnieuw mogelijk.

De verklaring was redelijk, variërend van $R^{2}$ adj $=0.232$ voor berk tot 0.714 voor uitheems loofhout, en in de meeste andere gevallen tussen 0.4 en 0.6 . Wel bleken veel parameters niet significant. 
In Figuur B2.4 is te zien hoe die grondvlakbijgroei kan worden omgezet naar een voorspelde diameter, hier voor het hele meettijdvak.

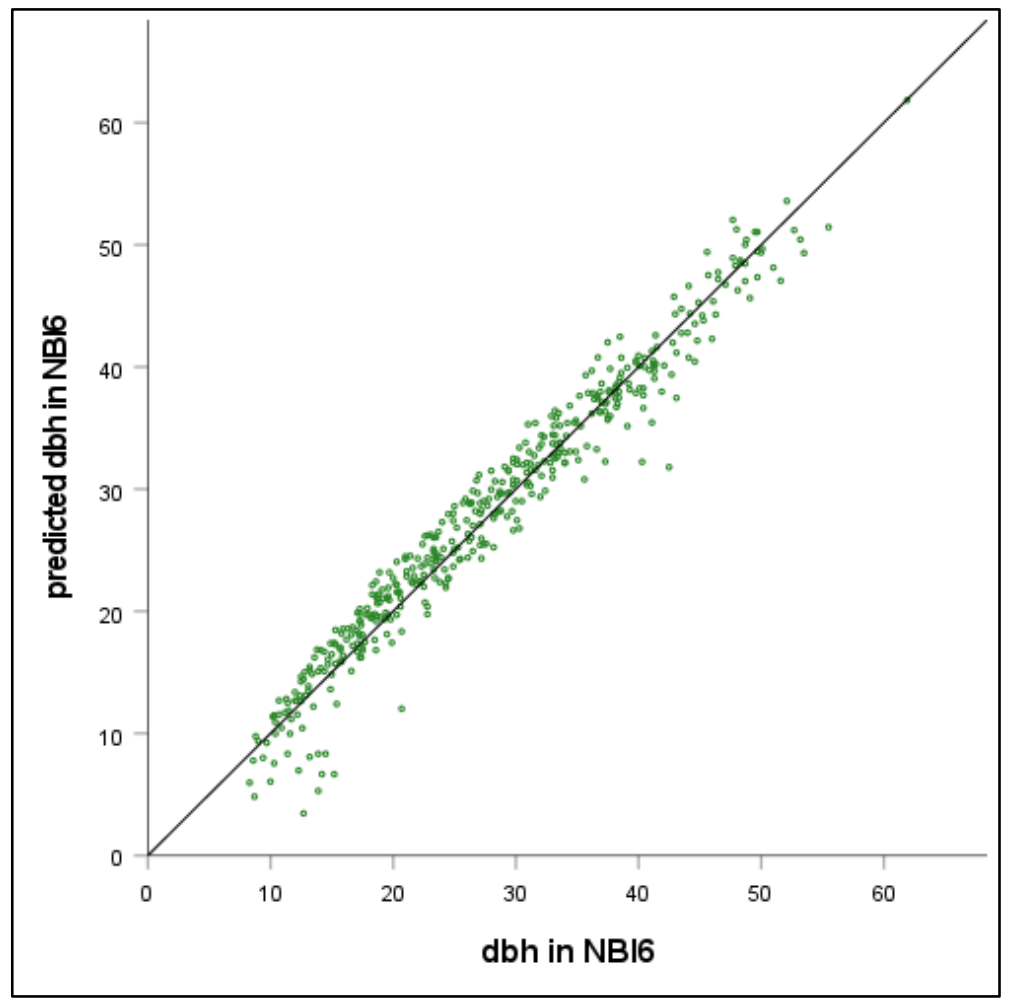

Figuur B2.4. Diameter en voorspelde diameter voor Corsicaanse den voor de geselecteerde bomen.

Maar zo'n voorspelling kan ook gebeuren door bij alle bomen uit de databases MFN en MBI6 de diameter na 1 jaar te voorspellen en dan de individuele volumebijgroei te voorspellen door beide waarden $d b h_{t}$ en $d b h_{t+1}$ vervolgens in een volumetarief in te voeren.

$\mathrm{Er}$ is sprake in het rapport over NBI-6 van aparte tarieven voor MFN en NBI-6. In principe is dit fout, omdat er dan impliciet van wordt uitgegaan dat de boomvorm afhankelijk is van het jaar van opname. Hierdoor ontstaat de mogelijkheid dat verschillen in volumebijgroei gebaseerd zijn op verschillen in volumetarief. Beter zou het zijn om één tarief per soortgroep te maken op basis van beide datasets Proefbomen.

\section{B2.6 Overige aandachtspunten}

De indeling in boomsoortgroepen is soms onduidelijk of inconsistent. Op pagina 67 dat zomereik en wintereik alleen als inlandse eik kunnen worden geclassificeerd en iets dergelijks geldt voor linde, terwijl er wel plaats is voor liguster (één maal waargenomen) en geoorde wilg en de kloon Italiaanse populier (beide niet waargenomen). Deze lijst betreft weliswaar de hoofdboomsoort van de opstand waarin het steekproefpunt ligt. Maar de daar gebruikte codering met twee letters wordt ook gebruikt voor individuele bomen in het plot. Bij NBI-7 staat dezelfde lijst overigens op pagina 26 van de Veldinstructie (Daamen et al., 2019). Op pagina 84 van het rapport treffen we een lijst aan met de soorten ten behoeve van de rapportage, dat betreffen alleen de soorten die 
in de verzamelgroepen Inheems loofhout, Uitheems loofhout, Stuiken en Overig Naaldhout zijn geplaatst. Drie opmerkelijke zaken hierbij:

1. Op pagina 69 in het rapport wordt het begrip struik gedefinieerd in "Struiklaagbedekking: Tot de struiklaag dienen te worden gerekend bomen en struiken die hoger zijn dan 2 meter, maar lager dan 6 meter". Maar op pagina 84 wordt de soortgroep Struiken alleen gedefinieerd als een lijstje van soorten, dus de boswilg in de Eyserbossen, met een stamomtrek van 3,43 m en een hoogte van $14 \mathrm{~m}$ zou indien getrokken in NBI- 6 per definitie een struik ${ }^{6}$ zijn.

2. De lijsterbes komt in dit lijstje met struiken niet voor en zou daarmee een individuele soort zijn. Echter, in de overzichten van bijvoorbeeld Tabel 5.5 en 10.2 komt lijsterbes niet voor dus hoort deze soort hetzij bij Struiken of bij Inheems loofhout; welke is niet duidelijk.

Daarnaast bleek er een discrepantie tussen de databases Plotgegevens en Boomgegevens. Zo kwam plot 55982 wel in de Boomgegevens voor en niet in de Plotgegevens. Iets vergelijkbaars deed zich voor bij plot 52831 (geen bosterrein volgens Plotgegevens, maar permanent plot in Boomgegevens).

Het nut van het bepalen van de opperhoogte in de plotgegevens wordt niet toegelicht en wordt alleen in de veldinstructie gebruikt.

\section{B2.7 Discussiepunten vooronderzoek}

Clerkx et al. (2017) geven in hun Eindrapportage Vooronderzoek NBI7 enkele discussiepunten aan over wijzigingen bij NBI-7. Van belang voor de steekproefmethode zijn daarbij:

Bosjes < 0,5 ha worden niet opgenomen bij NBI7, maar mogelijk wel bij NBI-8. Dezelfde opnametechniek is dan waarschijnlijk niet meer bruikbaar voor houtwallen singels en lanen. In de $4^{\mathrm{e}}$ Bosstatistiek is destijds gekozen voor Line Intersect Sampling, zie Schoonderwoerd (1981).

$\mathrm{Er}$ is voor gekozen om in principe alle plots permanent te maken, met als argumentatie dat dan (diameter)bijgroei rechtstreeks uit de data kan worden afgeleid. In wezen gaat het om het negeren van de mogelijkheid SPR-technieken te gebruiken.

Houtkwaliteit, zonder essentiële wijziging van de techniek wordt alleen nog aandacht besteed aan een select aantal boomsoorten met een diameter van $18 \mathrm{~cm}$ of meer, het streven is naar 1000 waarnemingen per soort. In de klem is een keuzeregel geprogrammeerd of de gegevens van een bepaalde boom moeten worden opgenomen. Onduidelijk is welke trekkingsprocedure daarbij is gevolgd.

Verjonging. Tot nu toe werd de verjonging bepaald binnen een straal van $5 \mathrm{~m}$ per boomsoort met een diameter $<5 \mathrm{~cm}$ en een hoogte van meer dan $2 \mathrm{~m}$. In NBI-7 wordt de straal vergroot naar $8 \mathrm{~m}$ en de ondergrens op een hoogte van $50 \mathrm{~cm}$ bepaald. Wel worden enkele categorieën uitgesloten van de steekproef.

Dit gaat om een single sampling plots (SSP) met een vaste straal. Een optie daarbij is om binnen een straal van $1 \mathrm{~m}$ verjonging te tellen voor de meest voorkomende soort tot kniehoogte $(50 \mathrm{~cm})$ en tot borsthoogte binnen een straal van $2 \mathrm{~m}$. Dan komen we uit op CSP (concentric sample points). Dat zou dan een aanbeveling kunnen zijn voor NBI-

\footnotetext{
${ }^{6}$ Bron: Leo Goudzwaard gemeten op 15 december 2010

https://www.monumentaltrees.com/nl/nld/limburg/gulpenwittem/2220_eyserbossen/3382/
} 
8. De methode werd gebuikt door Jop de Klein bij de inventarisatie van het Kolkbos op Schovenhorst, zie De Klein \& Jansen, 1992 en Jansen et al. 2019.

20 bomen methode. Hoewel in Bijlage 3 zal worden vastgesteld dat de twintig bomen methode geen significante bias oplevert ten opzicht van steekproefcirkels met een vaste straal heeft de methode wel een ander probleem. Als door de dynamiek het aantal bomen zodanig wijzigt dat bij heropname de straal moet worden aangepast krijgen we te maken met ongrowth of outgrowth van hele bomen. Daar is geen enkele theorie over bekend hoe daarmee moet worden omgegaan. Dit is een duidelijke aanleiding om over te stappen op single sampling plots (SSP) met een vaste straal of concentric sample points (CSP) met aparte stralen voor licht, middelzwaar en zwaar hout.

\section{B2.8 Conclusies}

Het steekproefontwerp van NBI-6 betreft een systematische steekproeftrekking van 100 ha vakken, waarbinnen een aselect getrokken steekproefpunt getrokken wordt. Dit punt valt in een bepaalde opstand. Hierbij is sprake van SPR (Sampling with Partial Replacement) en Double Sampling. De verwerking van de gegevens gaat echter uit van CFI (Continuous Forest Inventory). Dat is een gemist kans. Het axioma "het totale bosoppervlakte in Nederland is bekend" via de Bossenkaart is logistiek zeer werkbaar, maar discutabel omdat datum van de kaart en de opnamedatum verschillen .

Rond dat steekproefpunt ligt een plot met variabele omvang, hier worden de boomgegevens verzameld, dit zijn de fase 1 gegevens. Daarbinnen worden in fase 2 de gegevens van proefbomen bepaald. Door die variabele omvang is als gewicht de oppervlakte van het plot nodig. Dit is bij de verwerking correct toegepast.

Van de opstand waarin het steekproefpunt valt wordt deels administratief en deels in het veld basisinformatie verzameld. Het nut om daarbij een hoofdboomsoort te bepalen wordt al in het rapport ter discussie gesteld, en kan beter in fase 1 gebeuren.

De mogelijkheid om in plaats van het gebruik van volumetabellen in fase 2 van de double sampling, te kiezen voor directe bepaling van het volume via bijvoorbeeld TLS (terrestrial laser scanning) is een optie die de moeite van het onderzoeken waard is. Een optie daarbij kan zijn om alle bomen in fase 1 te scannen, daarmee vervalt fase 2 . Maar als de keuze tot enkele bomen in fase 2 beperkt blijft is het volumetarief te verbeteren door te kiezen voor het model van Berkhout, in plaats van dat van Hohenadl. In beide gevallen is het gewenst en mogelijk de variantie te berekenen. Het gebruik van een verschillende volumetarief voor opeenvolgende opnamen is niet gewenst.

De nauwkeurigheid van de gepresenteerde informatie is in het algemeen voldoende groot, maar gebruik van volumetarieven leidt wel tot mogelijke onbekende onzuiverheid. De steekproefomvang is voldoende.

Discrepanties tussen de datasets en de gepresenteerde gegevens in het rapport kwamen voor, maar waren van zeer beperkte omvang. 


\section{Bijlage 3: Schatters voor totalen per oppervlakte-eenheid bij variabele plotstralen}

Interne nota ten behoeve van Evaluatie NBI-7 door Dick Brus

\section{B3.1 Inleiding}

Dit document is een bijdrage aan de evaluatie van de steekproefopzet van de Nederlandse Bosinventarisaties (NBI). De nadruk ligt op de statistische aspecten van NBI.

Met de NBI data worden naast totalen ook gemiddeldes geschat, totalen per oppervlakte-eenheid, bijv. volume opgaand hout per ha. Deze doelgrootheid is gedefinieerd als

$$
\bar{z}=\frac{\sum_{i=1}^{N} t(z)}{A},
$$

met $t(z)$ het totaal in de populatie, en $A$ de oppervlakte van de populatie.

De bovenstaande doelgrootheid wordt geschat door de waargenomen (berekende) totalen van de plots te delen door de oppervlakte, en vervolgens het ongewogen gemiddelde van deze plotgemiddelden over de steekproefplots te berekenen:

$$
\hat{\bar{z}}=\frac{1}{n} \sum_{i=1}^{n} \frac{t_{i}(z)}{a_{i}},
$$

waarin $t_{i}(z)$ het waargenomen totaal van de $i$-de plot in de steekproef is, en $a_{i}$ de oppervlakte van deze plot. De steekproefplots vormen een systematische ongelijnde steekproef. De insluitkansen van de plots zijn dan ook even groot, waardoor gelijke gewichten voor de plots correct is.

In NBI hebben de steekproefeenheden (cirkelvormige plots) geen constant oppervlak. De straal van de plots is variabel. De straal is zo groot dat er minimaal 30 bomen met een diameter op borsthoogte ( $\mathrm{dbh}$ ) groter dan $5 \mathrm{~cm}$ voorkomen binnen de straal.

Hierdoor is deze NBI schatter van het populatiegemiddelde niet zuiver, m.a.w. er is een systematische fout. In dit document probeer ik door middel van een kleine simulatiestudie inzicht te krijgen in hoe groot deze systematische fout is. Verder wordt in dit document de toevallige en systematische fout van de NBI schatter vergeleken met de fouten van twee uit de steekproefliteratuur bekende schatters, de Horvitz-Thompson schatter en de ratio schatter. 


\section{B3.2 Simulatiestudie}

Stel onze populatie bestaat uit $N=300$ plots, waarvan 100 plots een oppervlakte hebben van 10 oppervlakte-eenheden, 100 plots een oppervlakte van 20 eenheden, en 100 plots een oppervlakte van 30 eenheden. Voor elke plot wordt een totaal gesimuleerd door oppervlaktefracties te simuleren en deze te vermenigvuldigen met de plot-oppervlakte. De oppervlaktefracties worden gesimuleerd door waardes van een hulpvariabele $x$ te trekken uit een normale verdeling met een gemiddelde van 0 en een standaardafwijking van 1 . Vervolgens wordt de inverse logit van de gesimuleerde $x$ waardes berekend.
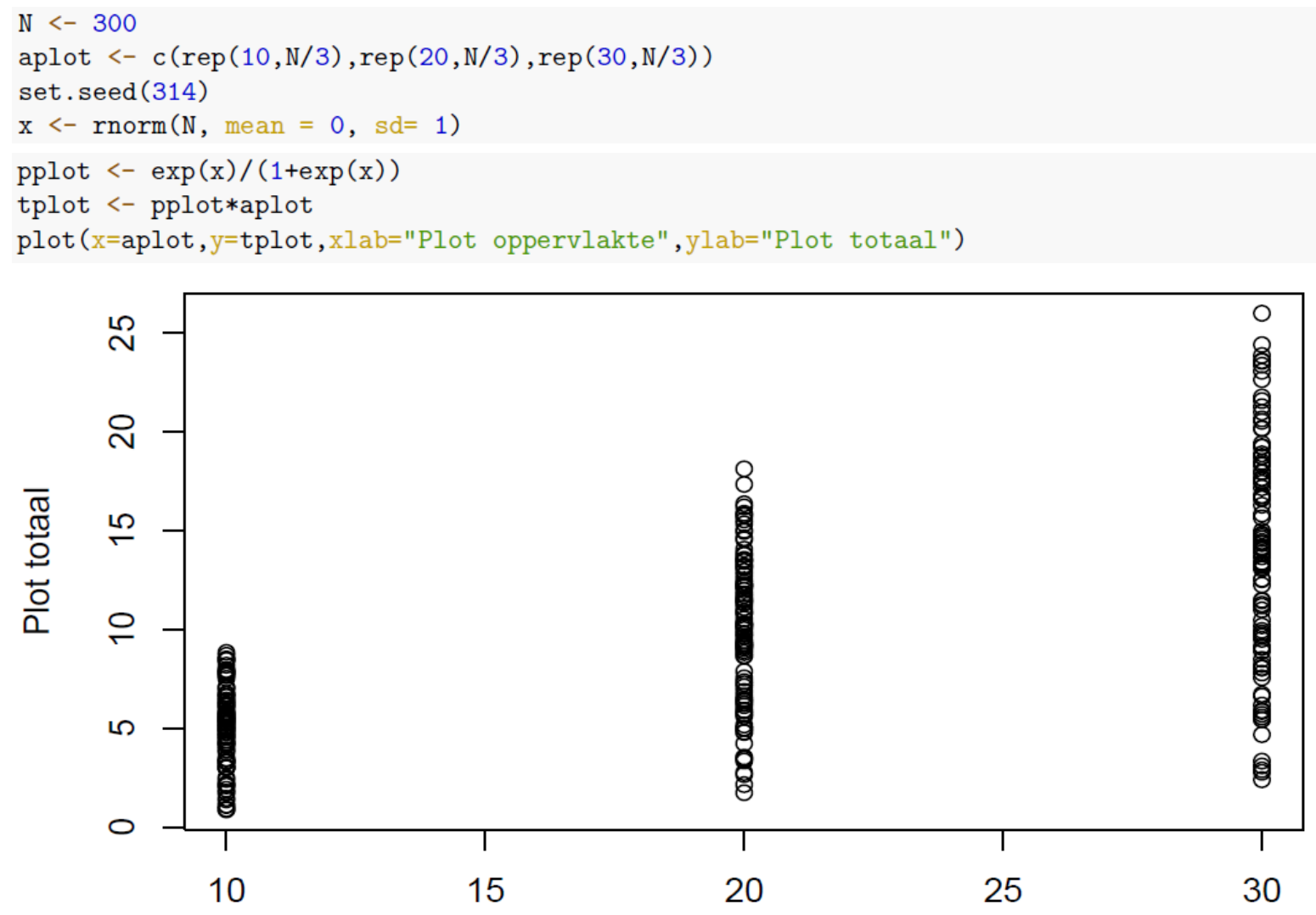

Plot oppervlakte

Het werkelijke populatiegemiddelde kan als volgt berekend worden:

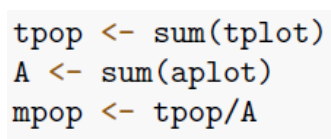

Het populatiegemiddelde is 0.478 .

Nu pas ik de NBI schatter (Vergelijking 2) toe op de hele populatie, m.a.w. we nemen aan dat we van alle 300 eenheden in de populatie zowel het totaal van de doelvariable als de oppervlakte hebben waargenomen.

mNBI <- mean(tplot/aplot)

Het populatiegemiddelde is dan 0.484. De twee berekende populatiegemiddeldes zijn niet aan elkaar gelijk. Wanneer we niet de hele populatie waarnemen, maar slechts een beperkt aantal gelote eenheden zal de NBI schatter (Vergelijking 2) niet zuiver zijn. Hierna worden twee alternatieve schatters van het populatiegemiddelde gepresenteerd. 


\section{B3.3 Schatters van populatiegemiddelde}

Stel we loten $n$ plots met gelijke insluitkansen, bijvoorbeeld enkelvoudig aselect of systematisch ongelijnd. Een zuivere schatter van het populatietotaal is de HorvitzThompson schatter

$$
\hat{t}(z)=\sum_{i=1}^{n} \frac{1}{\pi_{i}} t_{i}(z)=\frac{N}{n} \sum_{i=1}^{n} t_{i}(z),
$$

Waarin $\pi_{i}$ de insluitkans van de $i$-de plot is.

Het populatiegemiddelde kan dan zuiver geschat worden met

$$
\hat{\bar{z}}=\frac{\hat{t}(z)}{A},
$$

waarin $A$ het oppervlak is van de populatie.

Een alternatieve schatter van het populatiegemiddelde is de ratio-schatter:

$$
\hat{\bar{z}}=\frac{\hat{t}(z)}{\widehat{A}},
$$

Waarin $\widehat{A}$ de geschatte oppervlakte van de populatie is, geschat met

$$
\widehat{A}=\sum_{i=1}^{n} \frac{1}{\pi_{i}} a_{i}(z)=\frac{N}{n} \sum_{i=1}^{n} a_{i},
$$

waarin $a_{i}$ de oppervlakte is van de $i$-de plot in de steekproef. De ratio schatter van het populatie-gemiddelde kan dan ook geschreven worden als

$$
\hat{\bar{z}}=\frac{\sum_{i=1}^{n} t_{i}(z)}{\sum_{i=1}^{n} a_{i}} .
$$

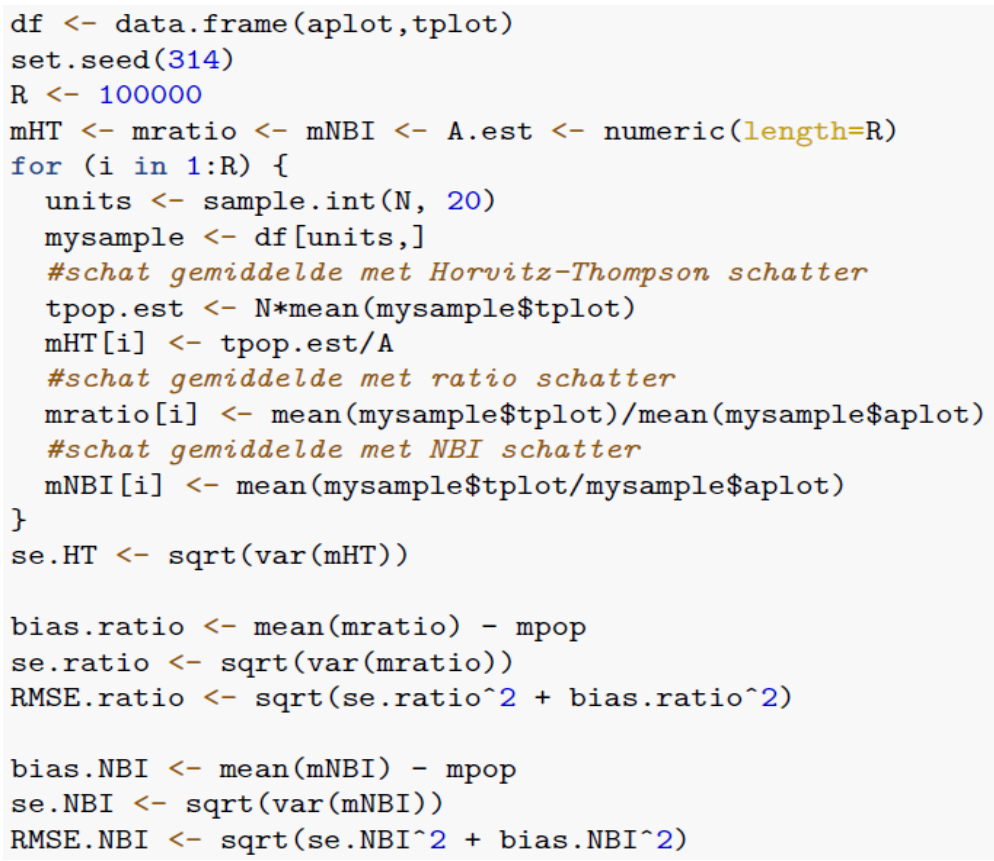


Het gemiddelde van de 100,000 Horvitz-Thompson schatters van het populatiegemiddelde is 0.477 , de standaardafwijking van deze 1000 schattingen is 0.06 . Geen significante afwijking van het werkelijke populatiegemiddelde dus. Analytisch kan aangetoond worden dat de Horvitz-Thompson schatter zuiver is, d.w.z. een systematische fout van 0, waardoor de RMSE gelijk is aan de standaardfout.

Het gemiddelde van de 100,000 ratio schatters van het populatiegemiddelde is 0.478 , met een standaardafwijking van 0.045 . De geschatte systematische fout is $2 \times 10-4$, en is dus verwaarloosbaar klein. De standaardfout is kleiner dan die van de HorvitzThompson schatter. De geschatte Root Mean Squared Error (RMSE) is 0.0452 .

Het gemiddelde van de 100,000 NBI schatters van het populatiegemiddelde is 0.484 , met een standaardafwijking van 0.043. De geschatte systematische fout is 0.0065 en is dus verwaarloosbaar klein. De geschatte RMSE is 0.0433 .

\section{B3.4 Conclusies}

1. De Horvitz-Thompson schatter is weliswaar zuiver, maar heeft in deze simulatiestudie een grotere standaardfout dan de andere twee schatters, en is daarom niet aan te raden.

2. In deze simulatiestudie is de systematische fout van de NBI schatter weliswaar iets groter dan die van de ratio schatter, maar nog steeds verwaarloosbaar klein. De standaardfout van de NBI schatter is iets kleiner dan die van de ratio schatter. Per saldo, op basis van systematische en toevallige fout, gecombineerd in de RMSE, zijn de NBI schatter en de ratio schatter ongeveer even accuraat.

3. Vanuit theoretisch oogpunt heeft de ratio schatter de voorkeur, aangezien deze goed theoretisch is onderbouwd. 


\section{Bijlage 4: Werkwijze evaluatie}

\section{Werkwijze en uitvoering}

Deze evaluatie is uitgevoerd in de periode van 8 maart tot 17 mei 2021.

\section{Samenstelling evaluatie team}

Coördinatie en synthese door prof.dr.ir. G.M.J. Mohren (WU-ESG) en dr.ir. J. den Ouden (WU-FEM), met inbreng door enkele (externe) deskundigen (dr. D.J. Brus Bodemkunde/Statistiek WEnR; ir. R. Haveman - biodiversiteit/vegetatiemonitoring BZK; ir. L. Govaere - ANB-BE, L. Schulze Middendorf, MSc - W\&H-NRW-DE; dr.ir. H.M. Bartholomeus - Remote Sensing - WU-GIS; E.A.H. Thomassen, MSc - Bosgroep Zuid / WUR-FEM; ir. J.J. Jansen - WU-FEM).

\section{Gesprekken en documenten}

Rapportage NBI-6 (Schelhaas et al., 2016)

Verslag werkgroep NBI-7

Verslag vooronderzoek

Veldinstructie Zevende Nederlandse Bosinventarisatie (2017-2021) (Daamen et al., 2017/2019)

Tussenevaluatie NBI-7

Verslagen NBI-7 begeleidingscommissie

Diverse interne notities o.a. over bossenkaart

Interviews/gesprekken:

Leden begeleidingscommissie NBI-7 (26 maart 2021): Ir. A. Willems (Kroondomein Het Loo), dr. M. Willemen (AVIH), ir. Z. Starmans (LNV), H. van Houten MSc (LNV), Ing. S. Clerkx (projectleider, WEnR), dr. E. Arets (LULUCF rapportage, WEnR)

Uitvoerders (26 maart 2021): S. Clerkx (projectleider, WEnR), M.J. Schelhaas (onderzoeker, WEnR), Ir. J. Oldenburger (Probos, dataverwerking), M. Lusing en ir. F. Dolstra (Borgman Beheer Advies), F. Voncken MSc en T. Scholten MSc (Bureau Van Nierop) 
